Edione Cristina dos Reis

Perfil genômico da resposta ao HIV-1 e implicações para a vacina terapêutica com células dendríticas contra o HIV-1

Dissertação apresentada ao Programa de Pósgraduação em Imunologia do Instituto de Ciências Biomédicas da Universidade de São Paulo, para obtenção do Título de Mestre em Ciências. 
Edione Cristina dos Reis

\section{Perfil genômico da resposta ao HIV -1 e implicações para a vacina terapêutica com células dendríticas contra o HIV-1}

Dissertação apresentada ao Programa de Pósgraduação em Imunologia do Instituto de Ciências Biomédicas da Universidade de São Paulo, para obtenção do Título de Mestre em Ciências.

Área de concentração: Imunologia

Orientadora: Alessandra Pontillo

Versão corrigida. A versão original eletrônica encontra-se disponível tanto na Biblioteca do ICB quanto na Biblioteca Digital de Teses e Dissertações da USP (BCTD). 
DADOS DE CATALOGAÇÅO NA PUBLICAÇÅO (CIP)

Serviço de Biblioteca e Informação Biomédica do

Instituto de Cièncias Biomédicas da Universidade de São Paulo

reproduçăo nåo autorizada pelo autor

Reis, Edione Cristina dos.

Perfil genômico da resposta ao HIV-1 e implicações para a vacina terapêutica com células dendríticas contra o HIV-1 / Edione Cristina dos Reis. - Säo Paulo, 2015

Orientador: Profa. Dra. Alessandra Pontillo.

Tese (Mestrado) - Universidade de São Paulo. Instituto de Ciências Biomédicas. Departamento de Imunologia. Área de concentraçäo: Imunologia. Linha de pesquisa: Imunogenética.

Versäo do título para o inglês: Genomic profile of anti-HIV response and outcome of dendritic cell-based therapeutic vaccine against HIV-1.

1. HIV-1 2. Imunoterapia 3. Células dendríticas 4. Ensaio clínico 5. Perfil genómico 6. Polimorfismos I. Pontillo. Profa. Dra. Alessandra

II. Universidade de Säo Paulo. Instituto de Ciências Biomédicas.

Programa de Pós-Graduação em Imunologia III. Título. 
UNIVERSIDADE DE SÃO PAULO

INSTITUTO DE CIÉNCIAS BIOMÉDICAS

\begin{abstract}
Candidato(a):
Edione Cristina dos Reis.

Título da Dissertação:

Perfil genômico da resposta ao HIV-1 e implicações para a vacina terapêutica com células dendríticas contra o HIV-1.
\end{abstract}

Orientador(a):

Profa. Dra. Alessandra Pontillo.

A Comissão Julgadora dos trabalhos de Defesa da Dissertação de Mestrado, em sessão pública realizada a .... . , considerou
( ) Aprovado(a)
( ) Reprovado(a)

\begin{abstract}
Examinador(a): $\quad$ Assinatura:
Nome:

Instituição:

Examinador(a): Assinatura:

Nome:

Instituição:

Presidente: Assinatura:

Nome:

Instituição:
\end{abstract}


A Comissấo de Etrica en Pesquisas em Seres hunnanos do ICB, na reunião realizada no dia 23.10.2013, APRovou o projeto intitulado: "Perfil genómico da resposta imune ao HIV-1 e implicaçöes para a vacina terapêutica com Céluias dendriticas contra o HN-1" da pesquisadora alessandra pontillo e aluna Edione Cristina dos Reis.

Cabe aos pesquisadores elaborar e apresentar a este Comitê, relatórios anuais (parciais e final), de acorco com a Resoluçäo no 466/12, itcm II, II.19 e II.20, do Conselho Nacional de Saúde, conforme modelo constante no site.icb.usp.br.

Ao pesquisador cabe também finalizar o processo junto à Plataforma Brasil quando do encerramento deste.

O primeiro relatório deverá ser encaminhado à Secretaria deste CFP em 23.10.2014.

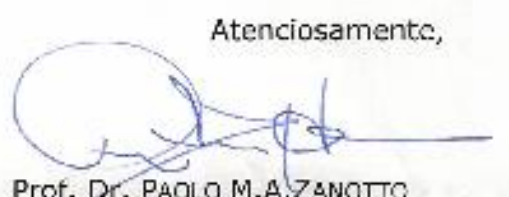

Prof. Dr. PAOLO M.A.ZANOTTO

Coordenador da Comissấo de Ética em Pesquisas com Seres Humanos - ICB/USP 


\section{AGRADECIMENTOS}

Àquela cuja participação nessa dissertação e na minha formação foi de fundamental importância, minha orientadora Alessandra.

Ao laboratório de Imunogenética (Pamela, Juliana, Elaine, Jaíne, Alexandre) pela amizade, paciência, colaboração e convivência agradável.

Aos amigos do LIM-56 pela disposição do laboratório, dia a dia e bons momentos.

À Dra Telma Oshiro e seu grupo (Bruna, Wanessa, Laís, Denise, Nathália, Marcella, Alexandre, "Ana Paula e Alana") por colocar a disposição reagentes, orientar experimentos e dividir comigo momentos de aprendizado e conhecimento e, acima de tudo, amizade .

Aos professores Dr. Niels Olsen e Dr. Condino pela disposição dos aparelhos utilizados em alguns dos meus experimentos.

Às agências de fomento: CAPES e FAPESP.

Aos meus pais pela dedicação e amor incondicional.

Aos meus irmãos pelo companheirismo.

Àquele que no decorrer dos últimos 2 anos passou de namorado, à noivo e marido sempre dando apoio, forças para continuar e acima de tudo muito amor.

Aos meus anjos de patas Glee, Bolinha e Barney por me darem apoio, alegria e esperança quando mais precisava.

Enfim, a todos que me ajudaram diretamente e indiretamente nessa etapa, o meu agradecimento! 
"ORir muito e com frequência; ganhar a respeito de pessoas inteligentes e a afeto das criansas; merecer a considerasão de críticos honestos ésuportar a traisão de falsos amigos; apreciar a beleza, encontrar a melhor nos outros; deixar a mundo um pouco melhor, seja por uma saudável criansa, um canteiro de jardim ou uma redimida condisão social; śaber que ao menos uma vida respirou mais fácil porque vacê vineu. Fsso é ter lido sucesso." 


\section{RESUMO}

REIS, E. C. Perfil genômico da resposta ao HIV-1 e implicações para a vacina terapêutica com células dendríticas contra o HIV-1. 2015. 92 f. Dissertação (Mestrado em Imunologia) - Instituto de Ciências Biomédicas, Universidade de São Paulo, São Paulo, 2015.

A imunoterapia baseada em células dendríticas (DC) tem sido reportada com uma interessante ferramenta para induzir o controle da carga viral plasmática. Neste estudo, foram analisados genes em DC, utilizadas em um ensaio clínico brasileiro, e em células mononucleares do sangue periférico (PBMC) antes e após o tratamento, com o objetivo de identificar marcadores preditivos da resposta à terapia. Para isso, a expressão gênica de genes envolvidos na resposta anti-HIV foi avaliada em 6 pacientes HIV+ submetidos à imunoterapia as diferentes etapas de diferenciação de monócitos a DC de acordo com o protocolo. Após isso, a expressão diferencial de genes de resposta a vacina e de controle viral do HIV foram avaliados em PBMC obtidos de 6 pacientes HIV+ antes e após o tratamento. Para a expressão diferencial foram utilizados um arranjo de genes comercialmente disponível e um customizado ( $\mathrm{RT}^{2}$ Profiler PCR Array, Qiagen). O perfil de genes de monócitos a DC mostrou que as células podem ser classificadas em dois grupos, um desses grupos mostrou uma ampla modulação de genes anti-HIV que aparentemente correlacionam com o aumento na ativação ou estado de exaustão celular e, possivelmente, com um pior produto vacinal, ainda que essa assinatura gênica não tenha sido estatisticamente associada a uma baixa funcionalidade da DC, talvez pelo limitado número de amostras. As comparações da modulação de expressão gênica em PBMC de pacientes HIV+ antes e após o tratamento mostrou uma boa resposta à imunoterapia associada com uma baixa modulação de genes específicos da resposta Th1 e assinatura de IFNs, enquanto que uma má resposta estava associada a uma alta modulação de genes envolvidos na inibição de resposta imune específica e exaustão imune. Nossos dados sugerem que uma triagem baseada na genética poderia auxiliar na predição da capacidade estimulatória da DC e no sucesso da imunoterapia em pacientes HIV+.

Palavras-chave: HIV-1. Imunoterapia. Células dendríticas. Ensaio clínico. Perfil genômico. Polimorfismos. 


\begin{abstract}
ABSTRAT
REIS, E. C. Genomic profile of anti-HIV-1 response and outcome of dendritic cell-based therapeutic vaccine against HIV-1. 2015. 92 p. Masters Thesis (Immunology) - Instituto de Ciências Biomédicas, Universidade de São Paulo, São Paulo, 2015.

Dendritic cells (DC)-based immunotherapy has been reported as an interesting approach to induce a control of plasma viral load in HIV positive (HIV+) individuals, however successes in clinical trials have been limited. In the current study, expression of selected genes was analysed in DC implied in a Brazilian on-going clinical trial and in peripheral blood mononuclear cells (PBMC) before and after the treatment, with the aim to identify a predictive marker for therapy responsiveness. For this purpose, differential expression of genes involved in host anti-HIV response was evaluated in 6 $\mathrm{HIV}+$ patients submitted to immunotherapy in different steps of monocytes-to-DC preparation according to immunotherapy protocol. Then differential expression of long term non progressor genes, general response to vaccine genes and HIV viral load control genes was evaluated in PBMC obtained from $6 \mathrm{HIV}+$ patients before and after the treatment. Commercially available and custom $\mathrm{RT}^{2}$ Profiler PCR Arrays (Qiagen) were used for differential expression analysis.

The genes profile of monocytes-to-DC revealed that cells can be classified into 2 groups, one with a larger modulation of a subset of anti HIV genes expression that apparently correlated with augmented cell activation/exhaustion state and possibly with a worse vaccine product, even if this gene signature was not statistically significant associated to a lower DC functionality, possibly due to the limited size of samples. Comparison of gene expression modulation in HIV+ patients PBMC after and before the treatment showed that a good response to immunotherapy associated with a low modulation of specific genes (Th1 response, type-I IFNs signature), whereas a bad response with a high modulation of genes involved in inhibition of specific immune response and immune exhaustion. Our data suggest that a genetic-based screen would help to predict DC-stimulatory capacity and success of immunotherapy in HIV+ patients.
\end{abstract}

Keywords: HIV-1. Immunotherapy. Dendritic cells. Clinical trial. Genomic profile. Polymorphisms. 


\section{LISTA DE ABREVIATURAS E SIGLAS}

$\mu \mathrm{l}$ : microlitro

14 h - DC: células dendríticas após 4 horas do pulso viral e 10 horas do estímulo com coquetel de citocinas

24 h - DC: células dendríticas após 4 horas do pulso viral e 20 horas do estímulo com coquetel de citocinas

4 h - DC: células dendrítica após 4 horas do pulso viral

48 h - DC: células dendríticas maduras

ACTB: $\beta$-actina

ADEE - 3002: Ambulatório de Imunodeficiências Secundárias 3002

AIDS: Síndrome da Imunodeficiência Adquirida

APOBEC3G: Apolipoprotein B mRNA editing enzyme, catalytic polypeptide-like $3 G$

ART: Terapia antirretroviral

AT-2: Aldrithiol-2

B2M: ß-2-microglobulina

CAPPesq: Comissão de Ética para Análise de Projetos de Pesquisa

CCL22: Chemokine (C-C motif) ligand 22

CCL3 (MIP-1a): Chemokine (C-C motif) ligand 3

CCL3L1: Chemokine (C-C motif) ligand 3-like 1

CCL4 (MIP-1ß): Chemokine (C-C motif) ligand 4

CCL5: Chemokine ( $C$-C motif) ligand 5

CCL7: Chemokine (C-C motif) ligand 7

CCR5: Chemokine (C-C motif) receptor 5

CCR7: Chemokine (C-C motif) receptor 7

CD14: cluster of differentiation 14

CD1a: cluster of differentiation 1

CD4+: cluster of differentiation 4

CD40 : cluster of differentiation 40

CD80: cluster of differentiation 80

CD83: cluster of differentiation 83

CD86: cluster of differentiation 86

cDNA: complementary DNA

CEP: Comitê de Ética em Pesquisa 
CGA: Análise de Gene Candidato

CNOT1: CCR4-NOT transcription complex subunit 1

$\mathrm{CT}$ : cycle threshold

CTL: Linfócito T citotóxico

CUL5: cullin 5

CVP: Carga Viral Plasmática

CXC12L: Chemokine (C-X-C Motif) Ligand 12

CXCR4 : $C$-X-C chemokine receptor type 4

DC: dendritic cell(s), célula(s) dendrítica(s)

DC-SIGN/CD209: Dendritic Cell-Specific Intercellular adhesion molecule-3-Grabbing Nonintegrin

DEFB1: Beta-defensin 1

DNA: Deoxyribonucleic acid

FC: Fold Change

FDR: False Discovery Rate

FMUSP: Faculdade de Medicina da Universidade de São Paulo

GAPDH: Glyceraldehyde-3-phosphate dehydrogenase

GM-CSF: Granulocyte-macrophage colony-stimulating factor

GWAS: Estudos de Associação Genômica Ampla

HDF: Fatores de dependência do HIV

HGDC: controle de contaminação com DNA genômico

HIV: Vírus da Imunodeficiência Humana

HLA: Human Leukocyte Antigens

HLA-DR: Human leukocyte antigens-DR

HLA-I: Human Leukocyte Antigen Class I

HPRT1: Hypoxanthine Phosphoribosyl-transferase 1

ICAM1: Intercellular Adhesion Molecule 1

iDC: dendrítica imatura

IFN $\gamma$ : interferon gama

IL10: Interleukin 10

IL12B: Interleukin 12

IL-18: Interleukin 18

IL1B: Interleukin-1 beta

IL4: Interleukin 4 


\section{IL6: Interleukin 6}

IRF-1: Interferon regulatory factor 1

IRF8: Interferon regulatory factor 8

LIM 56: Laboratório de Investigação Médica 56

MBL2: Mannose-binding lectin 2

NK: Natural Killer

NLRP3: NLR Family, Pyrin Domain Containing 3

NOS1: Nitric oxide synthase 1

NOS2A: Nitric oxide synthase 2A

PARD3B: Par-3 partitioning defective 3 homolog $B$

PBMC: Peripheral Blood Mononuclear Cell

PPC: controle positivo da PCR

RNA: ácido ribonucléico

ROCK1: Coiled-coil-containing protein kinase 1

RPLP0: Ribosomal Protein large PO

RTC: Reverse Transcription Control

SDF-1: Stromal cell-derived factor 1

SIV: Simian Immunodeficiency virus

SNPs: polimorfismos de base única

SOCS3: Suppressor of cytokine signaling 3

STAT5A: Signal transducer and activator of transcription 5A

TCD4+: Linfócitos T

TLRs :Toll-Like Receptors

TNF : fator de necrose tumoral

TRIM5: Tripartite motif-containing protein 5

UFPE :Universidade Federal de Pernambuco

VLPs $=$ Virus like particle 


\section{SUMÁRIO}

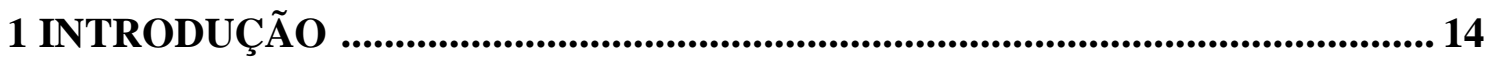

1.1 Fatores genéticos associados a infecção ao HIV-1 e progressão à AIDS ......... 17

1.2 Perfil genômico de pacientes HIV+ e resposta à vacina..................................... 20

1.3 Genômica funcional / transcriptômica ................................................................... 22

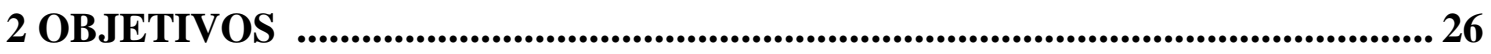

2.1 Objetivo geral ................................................................................................................... 26

2.2 Objetivos específicos ...................................................................................... 26

3 MATERIAIS E MÉTODOS .................................................................................... 27

3.1 Casuística do ensaio clínico de imunoterapia..................................................... 27

3.2 Desenho do estudo ..................................................................................... 28

3.3 Casuística utilizada nesse projeto ...................................................................29

3.4 Obtenção de vírus HIV inativado ..................................................................... 31

3.5 Obtenção de monócitos e células dendríticas derivadas de monócitos ............... 32

3.6 Obtenção de PBMC para estudo da resposta à imunoterapia........................... 32

3.7 Isolamento de RNA e retrotranscrição ......................................................... 32

3.8 Avaliação da expressão gênica durante a diferenciação monócitos-células dendríticas ............................................................................................................ 33

3.9 Análise da expressão gênica em resposta à imunoterapia .................................33

3.10 Avaliação da expressão gênica com sondas fluorogênicas gene-específicas e tecnologia Taqman .................................................................................................. 35

3.11 Análise por heat map e agrupamento hierárquico............................................... 36

3.12 Análise in silico das funções biológicas .......................................................... 36

3.13 Genotipagem com sondas alelo-específicas e tecnologia Taqman ................... 36

3.14 Avaliação fenotípica de células dendríticas ........................................................ 37

3.15 Avaliação da viabilidade celular .................................................................... 38

3.16 Análise funcional das células dendríticas: ensaios de co-cultivo ...................... 39

4 RESULTADOS E DISCUSSÃO- PARTE I ................................................. 40

4.1 Análise da expressão gênica em monócitos e células dendríticas derivadas de monócitos..................................................................................................................40

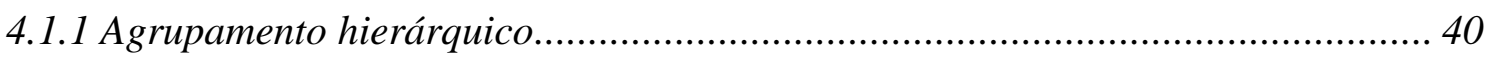

4.1.2 Modulação da expressão gênica dentro dos grupos A e B................................... 42

4.1.3 Modulação de genes relacionados com a morte celular e avaliação da

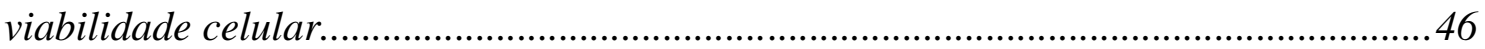

4.1.4 Modulação de genes relacionados com a resposta imune contra o HIV-1........... 47 
4.1.5 Modulação da expressão dos genes do inflamassoma. .48

4.1.6 Avaliação do fenótipo de maturação/ativação em monócitos e células dendríticas.....

4.1.7 Avaliação funcional de células dendríticas: capacidade de induzir produção

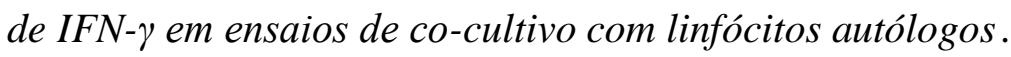

4.2 Discussão: etapas de diferenciação celular de monócitos em células dendríticas.

5 RESULTADOS E DISCUSSÃO- PARTE II.

5.1 Análise da expressão gênica em PBMC de indivíduos submetidos à imunoterapia 54

5.2 Análise por heat map e agrupamento hierárquico .55

5.3 Genes modulados em resposta à imunoterapia e análise da função biológica .. 59 5.4 Modulação da expressão dos genes NOS1 e MBL2 em PBMC após a imunoterapia 64

5.5 Modulação da expressão dos gene do inflamassoma em PBMC após a imunoterapia 65

5.6 Discussão: PBMC de indivíduos submetidos à imunoterapia .066 6 RESULTADOS E DISCUSSÃO- PARTE III .................................................... 70

6.1 Genotipagem dos pacientes submetidos à imunoterapia 70

6.1.1 Polimorfismos de base única previamente associados à resposta a imunoterapia para indivíduos $H I V+$ .70

6.1.2 Polimorfismos em fatores de restrição para o HIV-1 ..................................... 71

6.2 Discussão: genotipagem dos pacientes submetidos à imunoterapia.........................75

7 CONCLUSÃO .................................................................................... 77

REFERÊNCIAS ............................................................................................ 78

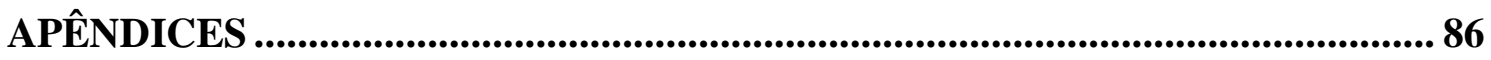

A - Perfil de expressão durante etapas de diferenciação de DC= P1-P6 (FC) ........ 86

B - Perfil de expressão de leucócitos após a imunoterapia= P6-P11 (FC).................88

C - Heat map do perfil de expressão dos leucócitos de 6 indivíduos HIV submetidos à imunoterapia nos tempos $\mathrm{t} 1$, $\mathrm{t} 2 \mathrm{e} \mathrm{t} 3$............................................8 89

D - Resultados Genemania modulação oposta entre P7 e maus respondedores .... 89

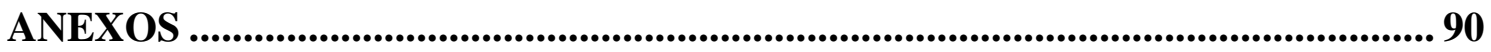

A - Arranjo de genes comercial usado nas etapas de diferenciação de DC..............90

B - Arranjo de genes customizado usado em leucócitos antes/após imunoterapia .91 


\section{INTRODUÇÃO}

A Organização Mundial de Saúde (OMS) estima que atualmente há aproximadamente 35,3 milhões de pessoas vivendo com o Vírus da Imunodeficiência Humana, (do inglês Human Immunodeficiency Vírus) ou com a Síndrome da Imunodeficiência Adquirida (AIDS, do inglês Acquired Immunodeficiency Syndrome) em todo o mundo. Dessas pessoas, mais de 9,7 milhões estão sob terapia antirretroviral (ART, do inglês Active Antiretroviral Therapy). No Brasil, de acordo com o último boletim epidemiológico há atualmente 734 mil pessoas vivendo com HIV/AIDS (BRASIL, 2013; YOUNAI, 2013).

Nessas últimas três décadas de epidemia, avanços científicos contribuíram para um melhor entendimento da resposta imune do hospedeiro, fornecendo assim subsídios para o desenvolvimento de potentes agentes antirretrovirais (YOUNAI, 2013). E mesmo que o número de indivíduos infectados tenha permanecido elevado, o advento da terapia antirretroviral levou à uma diminuição da mortalidade e morbidade da doença (VAN VAERENBERGH, 2001).

Os antirretrovirais aprovados e comercialmente disponíveis agem em estágios da replicação do HIV e consistem em: inibidores nucleosídeos e nucleotídeos para transcriptase reversa; inibidores não-nucleosídeos da transcriptase reversa; inibidores de protease; inibidores de fusão; inibidores de integrase; inibidores de entrada (antagonista de CCR5) e agentes combinados(CHEN; HOY; LEWIN, 2007; YOUNAI, 2013).

$\mathrm{Na}$ maioria dos indivíduos infectados pelo HIV-1 a administração de ART resulta no aumento da contagem de células TCD4+ e na redução da viremia plasmática que podem ser mantidos durante anos (CHEN et al., 2007; FINZI; SILICIANO, 1998).

Contudo, o sucesso da terapia antirretroviral é limitado pelo desenvolvimento de resistência, associada principalmente à interrupção da terapia que pode aumentar a replicação do HIV-1 presente em reservatórios latentes como células TCD4 ${ }^{+}$de memória (DAVEY et al., 1999).

São relatados também vários efeitos colaterais associados às interações medicamentosas com outros medicamentos e ao tempo de uso de ART prolongado, como complicações metabólicas (hiperglicemia, resistência insulínica, hiperlipidemia) e doenças cardiovasculares (CHEN et al., 2007; MURATA; HRUZ; MUECKLER, 2000).

É essencial nesse cenário desafiador o desenvolvimento de novas estratégias terapêuticas. Nesse contexto, surge a utilização de células dendríticas (DC, do inglês 
Dendritic Cells) na imunoterapia como uma alternativa complementar para o tratamento da infecção pelo HIV-1.

As DC constituem as mais potentes células apresentadoras de antígenos. São consideradas sentinelas naturais responsáveis por iniciar as respostas imunes mediadas por linfócitos $\mathrm{T}$ contra patógenos invasores e, desta forma, desempenhar um papel central na regulação imune (BANCHEREAU; STEINMAN, 1998).

$\mathrm{Na}$ infecção pelo HIV a quantidade de DC circulantes diminui drasticamente durante a progressão da doença (BARRON et al., 2003), dessa forma a administração de uma quantidade suficiente de DC estimuladas in vitro com antígenos de HIV representaria uma terapia complementar no controle da infecção, através do estímulo do sistema imune do próprio hospedeiro. Ou seja, as DC adequadamente ativadas poderiam melhorar a função deteriorada do sistema imune regulando importantes funções antivirais, tais como a mediação de anticorpos neutralizantes, citotoxicidade, lise dependente do complemento entre outras (PION et al., 2010). Os protocolos de vacinação terapêutica com DC têm como objetivo complementar o tratamento com antirretrovirais ao induzir o controle da carga viral plasmática em pacientes cronicamente infetados pelo HIV-1. Além disso, constitui uma importante ferramenta na investigação de correlato de imunogenicidade nesses pacientes.

Foram publicados vários ensaios clínicos utilizando imunoterapia de DC em indivíduos HIV+ (tabela 1). Embora os ensaios apresentem diferentes desenhos de estudo (preparação do imunógeno, desenho do ensaio, acompanhamento imunológico), a maioria mostrou algum grau de resposta imune relacionada com o controle da carga viral plasmática, embora com uma grande variabilidade individual na resposta (GARCIA; ROUTY, 2011). 
Tabela 1 - Ensaios clínicos baseados em imunoterapia com células dendríticas em indivíduos HIV+

\begin{tabular}{|c|c|c|c|c|c|c|c|c|}
\hline $\begin{array}{l}\text { Ensaio } \\
\text { clínico }\end{array}$ & $\begin{array}{l}\text { Sujeitos } \\
\text { (n) }\end{array}$ & Tratamento & DCs & $\begin{array}{l}\text { Maturação } \\
\text { DCs }\end{array}$ & Antígeno de HIV & Rota & $\begin{array}{l}\text { Resposta } \\
\text { virológica }\end{array}$ & $\begin{array}{c}\text { Resposta } \\
\text { imunogênica }\end{array}$ \\
\hline $\begin{array}{c}\text { Kundu, et al., } \\
1998\end{array}$ & 6 & naive & $2-8 \times 10^{6}$ & - & $\begin{array}{l}\text { rHIV-1 MN gp160 } \\
\text { ou gag, pol e env }\end{array}$ & $\begin{array}{c}\text { IV } \\
6-9 \\
\text { doses }\end{array}$ & $\begin{array}{l}\text { CV sem } \\
\text { alteração }\end{array}$ & CTL \\
\hline $\begin{array}{l}\text { Lu, et al., } \\
2004\end{array}$ & 18 & naive & $3 \times 10^{7}$ & $\begin{array}{l}\text { IL-1 } \beta, \text { IL-6 e } \\
\text { TNF- } \alpha\end{array}$ & $\begin{array}{c}10^{9} \text { HIV inativado } \\
\text { AT-2 }\end{array}$ & $\begin{array}{c}\text { SC } \\
3 \text { doses }\end{array}$ & $\begin{array}{l}\text { Queda CV } \\
(0,71 \log )\end{array}$ & $\begin{array}{l}\text { Aumento de } \\
\text { TCD }^{+} \text {e CTL }\end{array}$ \\
\hline $\begin{array}{l}\text { García, et al., } \\
2005\end{array}$ & 18 & TARV & $10^{6}$ & IFN- $\alpha$ & $\begin{array}{l}10^{9} \text { HIV inativado } \\
\text { calor }\end{array}$ & $\begin{array}{c}\text { SC } \\
4 \text { doses }\end{array}$ & $\begin{array}{l}\text { CV sem } \\
\text { alteração }\end{array}$ & $\begin{array}{l}\text { Aumento de } \\
\text { TCD4 } 4^{+} \text {e CTL }\end{array}$ \\
\hline $\begin{array}{l}\text { Ide, et al., } \\
2006\end{array}$ & 4 & TARV & $0,7-1,8 \times 10^{7}$ & TNF- $\alpha$ & $\begin{array}{l}\text { Peptídeos (gag, } \\
\text { nef e env) }\end{array}$ & $\begin{array}{c}\text { SC } \\
6 \text { doses }\end{array}$ & $\begin{array}{l}\text { CV sem } \\
\text { alteração }\end{array}$ & CTL \\
\hline $\begin{array}{l}\text { Connolly, et } \\
\text { al., } 2008\end{array}$ & 18 & TARV & $9,1 \times 10^{7}$ & $\begin{array}{l}\text { IL-1 } \beta, \text { IL-6 e } \\
\text { TNF- } \alpha\end{array}$ & $\begin{array}{l}\text { Peptídeos (gag, } \\
\text { pol e env) }\end{array}$ & $\begin{array}{c}\text { IV, SC } \\
2 \text { doses }\end{array}$ & TARV & CTL \\
\hline $\begin{array}{l}\text { Gandhi, et } \\
\text { al., } 2009\end{array}$ & 29 & TARV & $1,5-6 \times 10^{6}$ & $\begin{array}{c}\text { IL-6, IL-1 } \beta, \\
\text { TNG- } \alpha \text { e PGE }\end{array}$ & $\begin{array}{c}\text { Vetor viral + } \\
\text { peptídeos (gag, } \\
\text { pol e env) }\end{array}$ & $\begin{array}{c}\text { SC } \\
3 \text { doses }\end{array}$ & $\begin{array}{l}\text { CV sem } \\
\text { alteração }\end{array}$ & CTL \\
\hline $\begin{array}{c}\text { Kloverpris, et } \\
\text { al., } 2009\end{array}$ & 12 & naive & $10^{7}$ & $\begin{array}{c}\text { IL-1 } 1 \beta, \text { IL-6, } \\
\text { TNF- } \alpha \text { e PGE } 2\end{array}$ & Pool de peptídeos & $\begin{array}{c}\text { SC } \\
4 \text { doses }\end{array}$ & $\begin{array}{l}\text { CV sem } \\
\text { alteração }\end{array}$ & - \\
\hline $\begin{array}{l}\text { Routy, et al., } \\
2010\end{array}$ & 10 & TARV & $10^{7}$ & $\begin{array}{l}\text { TNF- } \alpha, \text { IFN- } \nu \\
\text { e PGE } 2\end{array}$ & $\begin{array}{l}\text { Peptídeos (gag, } \\
\text { Vpr, rev e env) }\end{array}$ & $\begin{array}{c}\text { ID } \\
4 \text { doses }\end{array}$ & TARV & $\begin{array}{l}\mathrm{TCD}^{+} \text {e TCD8 } \\
\text { HIV-específicos }\end{array}$ \\
\hline $\begin{array}{c}\text { García, et al., } \\
2011\end{array}$ & 24 & naive & $8 \times 10^{6}$ & $\begin{array}{l}\text { IL-1 } \beta, \text { IL-6 e } \\
\text { TNF- } \alpha\end{array}$ & $\begin{array}{l}10^{9} \text { HIV inativado } \\
\text { calor }\end{array}$ & $\begin{array}{c}\text { SC } \\
3 \text { doses }\end{array}$ & $\begin{array}{c}\text { Queda CV } \\
(0,5 \log )\end{array}$ & $\begin{array}{c}\text { TCD8 }^{+} \\
\text {HIV-específicos }\end{array}$ \\
\hline $\begin{array}{l}\text { Routy, et al., } \\
2011\end{array}$ & 29 & TARV & $10^{7}$ & $\begin{array}{l}\text { TNF- } \alpha, \text { IFN- }-\gamma \\
\text { e PGE } 2\end{array}$ & $\begin{array}{l}\text { Peptídeos (gag, } \\
\text { Vpr, =rev e env) }\end{array}$ & $\begin{array}{c}\text { ID } \\
4 \text { doses }\end{array}$ & Queda CV & CTL \\
\hline $\begin{array}{c}\text { García, et al., } \\
2013\end{array}$ & 23 & TARV & $10^{7}$ & $\begin{array}{c}\text { IL-1 } 1 \beta, \text { IL-6, } \\
\text { TNF- } \alpha \text { e PGE } 2\end{array}$ & $\begin{array}{c}10^{9} \text { HIV inativado } \\
\text { calor }\end{array}$ & $\begin{array}{l}3 \text { doses } \\
\text { ID/SC }\end{array}$ & Queda CV & $\begin{array}{l}\text { Aumento de } \\
\mathrm{TCD} 4^{+} \mathrm{CD} 38^{+}\end{array}$ \\
\hline
\end{tabular}

TARV: terapia antirretroviral; IV intravenosa; SC: subcutânea; ID: intradérmica; CV: carga viral; CTL: linfócitos T citotóxicos. (CONNOLLY et al., 2008; GANDHI et al., 2009; GARCIA et al., 2011; GARCIA et al., 2005; IDE et al., 2006; KLOVERPRIS et al., 2009; KUNDU et al., 1998; LU et al., 2004; ROUTY et al., 2010) Adaptado de (GARCIA; ROUTY, 2011).

Dentre esses estudos, um exemplo expressivo foi demonstrado por Lu et al. (2004). No entanto, antes disso o mesmo grupo (LU et al., 2003) mostrou que uma vacina terapêutica constituída por DC pulsadas com SIV (do inglês, Simian Immunodeficiency Virus) inativado foi capaz de estimular uma resposta celular e humoral efetiva em macacos, promovendo o controle da replicação viral nos tecidos linfoides secundários e a redução da carga viral.

Posteriormente esse mesmo grupo, em colaboração com pesquisadores da UFPE, desenvolveu um ensaio clínico de fase I vacinando 18 pacientes brasileiros (procedentes da região metropolitana de Recife, PE) cronicamente infectados pelo HIV-1 (HIV+), sem uso de tratamento antirretroviral, com DC autólogas pulsadas in vitro com HIV-1 autólogo quimicamente inativado por aldrithiol-2 (LU et al., 2004; ROSSIO et al., 1998). Nesta primeira fase, 15 dos 18 indivíduos vacinados apresentaram uma desaceleração na progressão 
da doença. Além disso, após um ano de tratamento 8 de 18 indivíduos apresentaram uma prolongada redução na carga viral plasmática, correlacionada a uma vigorosa resposta imune celular, com ativação de linfócitos T CD4+ e CD8+, traduzida inclusive por um aumento dos linfócitos T CD4+ circulantes. O declínio da carga viral dos pacientes foi significativamente correlacionado com a expressão de perforina nas células T CD8+ HIV-1 gag-específicas e das células CD4+ T helper HIV-1-específicas (LU et al., 2004).

A segunda fase desse ensaio clínico (LU et al., 2004) foi desenvolvida pelo grupo da Dra. Telma M Oshiro do Laboratório de Investigação Médica/LIM-56 da Faculdade de Medicina da Universidade de São Paulo/FMUSP liderado pelo Prof. Alberto JS Duarte. Nesse ensaio clínico foram vacinados outros 19 pacientes HIV+ brasileiros procedentes da região metropolitana de São Paulo. Além da vacinação terapêutica e acompanhamento clínico, estão ainda em andamento projetos de pesquisas relacionados que pretendem investigar várias questões relacionadas à utilização da vacina em pacientes HIV+. Dentre elas, a parcialidade da resposta entre os indivíduos vacinados observada na fase I, ou seja, o porquê de alguns pacientes terem um perfil de bom ou mau respondedor ao tratamento e quais fatores poderiam influenciar o resultado da terapia. A descrição de novos marcadores moleculares sugestivos da capacidade de resposta a esse tipo de tratamento também está sendo investigada.

O perfil de bom ou mau respondedor pode depender de vários fatores, como a qualidade da DC obtida in vitro a partir da diferenciação de monócitos do sangue periférico (perfil fenotípico, viabilidade, ativação completa e eficaz) e a habilidade do próprio sistema imune do paciente em ser ativado por essa DC manipulada. Considerando que a resposta imune dos indivíduos ao HIV é amplamente comprometida pela própria infecção, questões sobre a responsividade à vacina baseada em DC são estritamente correlacionadas com a habilidade de cada indivíduo em conter a infecção. Nesse sentido, informações sobre o histórico clínico do paciente HIV+ (carga viral plasmática/CVP, contagem de CD4+), assim como marcadores moleculares ainda desconhecidos podem ser úteis na seleção de possíveis indivíduos beneficiados com esse tipo de intervenção.

Enquanto o grupo da Dra. Telma Oshiro está pesquisando aspectos celulares da resposta à vacina, o nosso grupo esta mais focado na caracterização do perfil genômico dessa resposta.

\subsection{Fatores genéticos associados à infecção ao HIV-1 e progressão à AIDS}

A identificação de genes que afetam a susceptibilidade e resistência ao HIV-1 pode ser a chave para descobrir importantes interações HIV-hospedeiro para o desenvolvimento de 
tratamentos e vacinas.

Um exemplo disso ocorreu em 1996 quando foi descrita uma deleção de 32 pares de bases no gene do receptor de quimiocina tipo 5 CCR5 (CCR5 $\Delta 32$ ) que confere proteção contra a infecção pelo HIV em homozigotos (DEAN et al., 1996; O'BRIEN; NELSON, 2004). Essa foi a primeira evidência convincente de que a transmissão de cepas de HIV, preferencialmente utiliza o correceptor CCR5 para entrada de célula. O que levou ao desenvolvimento de uma nova classe de medicamentos anti-HIV que inibe a entrada do vírus na célula (DEAN et al., 1996). Recentemente, um paciente HIV-1-positivo foi curado após o transplante de células tronco CCR5 $\Delta 32 / \Delta 32$ (HÜTTER et al., 2009). Esse caso isolado ilustra o potencial da pesquisa em genética translacional no combate ao HIV/AIDS.

Nos últimos anos tem sido intensificada a busca por fatores genéticos de restrição a infecção pelo HIV, dado que 30 anos após a descoberta do HIV ainda não se tem uma vacina eficaz. Ao contrário do HIV que pode desenvolver resistência através de mutações de escape, os hospedeiros são geneticamente estáveis e, por isso consistem em bons alvos de estudo.

Usando uma combinação de Análise de Gene Candidato (CGA) e Estudos de Associação Genômica Ampla (GWAS) foram identificadas variantes genéticas entre indivíduos infectados que explicam, em parte, a variação observada na susceptibilidade a HIV-1/AIDS. Estes genes são principalmente divididos em três classes: imunidade inata e adaptativa, fatores intrínsecos de restrição antiviral e fatores de dependência do HIV exigidos pelo HIV para replicação (AN; WINKLER, 2010).

A entrada do HIV-1 nas células é influenciada por várias interações com receptores e ligantes. Amplamente investigados, os receptores de quimiocinas e os seus ligantes desempenham um papel-chave na entrada do HIV nas células. O HIV-1 entra nas células CD4+ através da ligação a um dos dois principais correceptores: CCR5 utilizado por cepas transmitidas de HIV-1 (R5), ou CXCR4 utilizado por cepas X4 que surgem em cerca de 50\% dos indivíduos durante a infecção tardia (MURAKAMI; YAMAMOTO, 2010).

Os polimorfismos no receptor de quimiocina CCR5 e a variação do número de cópias do gene que codifica o seu ligante (CCL3L1), importante para a função de supressão do HIV, são determinantes da susceptibilidade ao HIV-1/AIDS (GONZALEZ et al., 1999; MANGANO et al., 2001). As variações em CCL3L1 e CCR5 são classificadas como grupos de risco genético baixo, moderado e alto e podem interferir na patogênese da infecção pelo HIV. Essa interferência pode influenciar parâmetros que são dependentes da entrada viral (por exemplo, a carga viral plasmática) e os parâmetros que são independentes da entrada viral (por exemplo, resposta imune do hospedeiro) (DOLAN et al., 2007). As quimiocinas CCL5 
(RANTES), CCL3 (MIP-1 $\alpha$ ) e CCL4 (MIP-1 $\beta$ ) são ligantes do CCR5 e R5, inibindo competitivamente a entrada de HIV R5 nas células. CXC12L (SDF-1) é ligante de CXCR4 e influencia a entrada do vírus HIV X4. Polimorfismos nos genes CCL5 e SDF-1 também foram respectivamente associados com a rápida e lenta progressão para AIDS (AN et al., 2002; WINKLER et al., 1998).

O HIV-1 utiliza os mecanismos de reconhecimento de patógenos do sistema imune para entrar na célula. As variações em receptores da imunidade inata como DC-SIGN/CD209, expresso pelas DC; MBL2, receptor solúvel responsável pela ativação do sistema do complemento e da fagocitose, e peptídeos antimicrobianos como as defensinas influenciam a entrada do vírus nas células e consequentemente a susceptibilidade ao HIV-1 e a taxa de progressão da doença (BONIOTTO et al., 2003; JI; GEWURZ; SPEAR, 2005; MILANESE et al., 2006).

Uma vez que o HIV-1 ganha acesso à célula alvo, outros mecanismos citoplasmáticos entram em ação, tais como as proteínas da família de citidinas deaminase APOBEC3G, proteínas envolvidas na ubiquitinação (cullin 5/CUL5, TRIM5) (AN; WINKLER, 2010) e receptores intracelulares que podem mediar a ativação de uma resposta imune inflamatória, como foi recentemente demonstrado para o Nod-Like Receptor-3 (NLRP3) pelo nosso grupo de pesquisa (PONTILLO; SILVA; et al., 2012). Polimorfismos nestes genes também foram avaliados em relação a susceptibilidade à infecção pelo HIV-1 e a progressão à AIDS (AN; WINKLER, 2010; PONTILLO et al., 2010; PONTILLO; OSHIRO; et al., 2012).

A resposta imune inflamatória responsável pela restrição da infecção também é afetada por variações genéticas em genes de citocinas e/ou receptores IL1B, (PONTILLO; OSHIRO; et al., 2012) IL10, IFN $, I R F-1, C X C R I(A N ;$ WINKLER, 2010).

A intersecção entre a imunidade inata e adquirida manifesta-se por efeitos interativos de HLA e dos receptores KIR das células natural killer (NK) sobre o HIV. Os alelos HLA de classe I (HLA-1) foram os primeiros fatores genéticos do hospedeiro identificados na susceptibilidade à AIDS. Genes do complexo HLA I codificam moléculas da superfície celular que apresentam diferencialmente epítopos antigênicos do vírus para os linfócitos $\mathrm{T}$ CD8 + citotóxicos (CTL). Alelos específicos de HLA-I, através da diferente ligação de epítopos do HIV, influenciam a eficácia da resposta do sistema imunológico, afetando assim a progressão à AIDS (CARRINGTON; MARTIN; VAN BERGEN, 2008; CARRINGTON; O'BRIEN, 2003). A morte das células infectadas mediada por CTL CD8+, após o reconhecimento de epítopos de HIV apresentados por receptores HLA-I, é essencial para o controle imunológico do HIV. Por outro lado mutações dos epítopos permitem ao HIV escape 
deste controle. Homozigotos para HLA-I A, B, C, que reduzem o repertório de reconhecimento de epítopos (CARRINGTON et al., 1999; TANG et al., 2008), e o alelo B*35-Px, que reduz a força de ligação pelo epítopo (GAO et al., 2001), aceleram a progressão à AIDS. Do mesmo modo que a concordância de HLA-I limita o repertório de epítopos apresentados, também aumenta a transmissão do vírus (MACKELPRANG et al., 2008). Ao contrário, os alelos B*27 e B*57 impedem o escape imune do HIV e desaceleram a progressão à AIDS (CARRINGTON et al., 2008).

Uma estratégia de adaptação apresentada pelo HIV e outros vírus é a de regular negativamente a expressão de HLA-I, bloqueando assim a apresentação de epítopos virais e impedindo a lise das células infectadas pelos CTL. Uma função das células NK para contrariar esta estratégia é reconhecer e eliminar células que deixam de exibir níveis corretos de HLA-I através dos receptores KIR. Variações nos genes KIR também foram associadas com a progressão à AIDS (AN; WINKLER, 2010).

A susceptibilidade genética à infecção pelo HIV- 1 e à progressão da doença foi estudada por vários pesquisadores para identificar genes que poderiam modular as etapas da infecção viral e replicação, tentando esclarecer a variabilidade interpessoal da infecção pelo HIV-1. Na realidade, as consequências clínicas da exposição viral são variáveis, mostrando

que alguns indivíduos podem ser repetidamente expostos ao vírus e permanecerem livres da infecção, ou podem ser infectados e manter-se sem manifestações clínicas da doença. Outros são infectados e rapidamente progridem para a AIDS. A susceptibilidade e a evolução da infecção pelo HIV são fenômenos complexos, resultado da interação de fatores ambientais e das informações genéticas do hospedeiro (CHATTERJEE et al., 2012).

\subsection{Perfil genômico de pacientes HIV+ e resposta à vacina}

Apesar de que as vacinas profiláticas sejam amplamente utilizadas na prática clínica, o conhecimento dos mecanismos subjacentes à indução de uma resposta imune protetora é ainda limitado. Nas últimas décadas a grande atenção sobre os componentes da imunidade inata e seu papel em dirigir a resposta imune adaptativa trouxe novo conhecimento sobre as ferramentas utilizadas pelo sistema imune para o reconhecimento de patógenos e a ativação duradoura e específica de linfócitos T e/ou B promovida por uma vacina (CHATTERJEE et al., 2012).

A biologia de sistemas (systems biology) oferece uma visão integrada dos mecanismos e das interações que acontecem na resposta à uma vacina considerando os três elementos 
biológicos envolvidos: a vacina, a imunidade inata e a imunidade adaptativa. Esse tipo de análise é baseada em vários níveis: genética, transcriptômica e proteômica, cada um fornecendo uma "assinatura" do hospedeiro em resposta à uma vacina. O estudo dessas "assinaturas" biológicas, individualmente ou integradas, pode fornecer uma ferramenta potente para uma análise multiparamétrica de predição da imunogenicidade de uma vacina. A análise de polimorfismos genéticos representa um nível deste estudo complexo de fatores envolvidos na resposta do hospedeiro a antígenos, e consequentemente a resposta à uma vacina. Os polimorfismos podem afetar as proteínas do sistema imune ou a sua expressão e, deste modo, afetar também interações patógeno-hospedeiro e vias de sinalização molecular. Por exemplo, polimorfismos nos genes Toll-Like Receptors (TLRS), receptores da imunidade inata envolvidos no reconhecimento de patógenos extra e intracelulares, foram associados à susceptibilidade à bactéria gram-negativa, a vírus como sarampo e rubéola e também a resposta à vacina contra sarampo, rubéola e pertussis (BUONAGURO; PULENDRAN, 2011).

Enquanto muita atenção tem sido dada para elucidar o impacto do genoma viral na propagação do HIV-1 e no desenvolvimento de uma vacina contra o HIV-1, pouco se sabe sobre o impacto de fatores do hospedeiro sobre esses eventos.

Apesar disso, alguns trabalhos tem sugerido uma relevante contribuição da genética do hospedeiro na propagação da infecção pelo HIV-1. Alguns autores sugeriram que as variações genéticas (ex. polimorfismos em CCR5, CCL3L1, DC-SIGN, HLA-I, APOBEC3G, TRIM5, $M B L 2, D E F B 1, N L R P 3)$ relacionadas com a susceptibilidade a infecção pelo HIV-1 e/ou com a progressão à AIDS poderiam estar associadas também a uma resposta diferencial a uma vacina anti-HIV-1 (BAKER et al., 2009). Além disso, a determinação da frequência destes alelos/genótipos de risco poderia ser utilizada para avaliar a eficácia de uma vacina numa população.

Através de um modelo matemático, Kulkarni e colaboradores (KULKARNI et al., 2008) propuseram que polimorfismos nos genes CCR5 (principal correceptor do HIV - 1) e CCL3L1 (ligante do CCR5 e quimiocina supressiva do HIV-1) seriam os determinantes mais conhecidos da susceptibilidade a HIV/AIDS e que poderiam afetar a eficácia de uma vacina contra o HIV-1. Partindo da mesma hipótese, Fellay (FELLAY et al., 2011) avaliou os determinantes genéticos específicos da resposta dos linfócitos $\mathrm{T}$ nos indivíduos do ensaio clínico da vacina MRKAd5 HIV-1 gag/pol/nef. Apesar de não atingir resultados estatisticamente significantes, esse estudo indicou alguns polimorfismos no complexo HLA de classe I como possivelmente associados com a resposta dos linfócitos T a proteína HIV- 
gag.

Para tentar explicar as diferenças encontradas nos 18 pacientes HIV+ submetidos à primeira fase da vacina baseada em DC autólogas pulsadas com HIV-1 autólogo inativado (ensaio clínico com a coorte de Recife de Lu e colaboradores em 2004) (LU et al., 2004), o nosso grupo de pesquisa, em colaboração com o Laboratório de Variabilidade Genética Humana da UFPE liderado pelo Prof. Sergio Crovella, participou do estudo genético ao caracterizar geneticamente a capacidade dos indivíduos de responder ou não ao tratamento.

Inicialmente os 18 indivíduos do ensaio clínico foram genotipados para 768 polimorfismos de base única (SNPs) distribuídos em 146 genes envolvidos na resposta imune. Esse estudo de associação mostrou que genes da resposta imune (PLCB1, RHOC, ROCK1, NOS2A, PIK3R1, CCL7, IL4), e especialmente da imunidade inata, MBL2 e NOS1, estavam relacionados com a resposta à vacina, ou seja com a diminuição da carga viral plasmática (SEGAT et al., 2010).

Em seguida, outros dois trabalhos mostraram que o fator CNOT1, envolvido no controle pós-transcricional de genes inflamatórios e na replicação do HIV-1, estaria associado à resposta vacinal (MOURA et al., 2014), assim como o gene PARD3B, que codifica um dos fatores de restrição viral (PONTILLO et al., 2014).

Esses resultados sugerem que os pacientes HIV+ submetidos à primeira fase da vacina eram possivelmente indivíduos que conseguiam controlar a carga viral plasmática ao menos temporariamente. Assim, é possível que, entre estes indivíduos, alguns pudessem ter um genoma pouco suscetível ao HIV-1. Uma possível explicação da resposta à vacina de alguns pacientes HIV+ seria a presença de variações genéticas pouco "permissivas" à infecção/progressão a AIDS.

\subsection{Genômica funcional / transcriptômica}

A genômica funcional pode responder a outras questões em aberto sobre a imunoterapia, entre elas duas se destacam: o perfil de expressão gênica pode ser utilizado para avaliar a qualidade e funcionalidade das DC utilizadas na vacina? O estudo da variação na expressão gênica antes e após a vacina possibilitaria definir alguns marcadores específicos de resposta?

Em ensaios clínicos, o sucesso da utilização de células dendríticas em vacinas terapêuticas pode ter sido limitado, o que pode ser atribuído a uma falta de marcadores da qualidade das DC utilizadas. Vários grupos de pesquisa tentaram identificar marcadores de 
funcionalidade das DC através do estudo do perfil de expressão gênica das DC estimuladas com diferentes antígenos, porém os dados são heterogêneos e dependentes do modelo (humano ou murino) e do desenho experimental utilizado (tabela 2).

Tabela 2 - Estudos baseados no perfil transcricional de células dendríticas

\begin{tabular}{|c|c|c|c|}
\hline Estudo & Células e estímulos & Perfil de expressão & Metodologia \\
\hline $\begin{array}{l}\text { TORRI et al., } \\
2010\end{array}$ & $\begin{array}{l}\text { DC murinas ativadas } \\
\text { com estímulos pró- } \\
\text { inflamatórios }\end{array}$ & $\begin{array}{l}\text { IL6, IL12B, IL1B, CCL22, } \\
C D 40, \\
\text { SD83, CD86, ICAM1, }\end{array}$ & $\begin{array}{l}\text { Affymetrix } \\
\text { mouse MG- } \\
\text { U74Av2 } \\
\text { GeneChip }\end{array}$ \\
\hline $\begin{array}{l}\text { TUANA et al., } \\
2011\end{array}$ & $\begin{array}{l}\text { DC de camundongo } \\
\text { inflamada }\end{array}$ & IL12B, CD40 e SOCS3 & $\begin{array}{l}\text { Affymetrix } \\
\text { mouse array }\end{array}$ \\
\hline LIU et al, 2012 & $\begin{array}{l}\text { DC humanas } \\
\text { imaturas/pulsadas } \\
\text { com antígenos } \\
\text { tumorais }\end{array}$ & genes de TLRs, MHC de classe II & $\begin{array}{l}\text { Illumina } \\
\text { human } \\
\text { HT12-v3 }\end{array}$ \\
\hline $\begin{array}{l}\text { PONTILLO; } \\
\text { SILVA; et al., } \\
2012\end{array}$ & $\begin{array}{l}\text { DC diferenciadas a } \\
\text { partir de monócitos } \\
\text { de } \\
\text { infectados pelo HIV }\end{array}$ & $\begin{array}{l}\text { expressão basal de componentes do } \\
\text { inflamassoma e de } I L-1 \beta\end{array}$ & $\begin{array}{l}\text { Ensaios } \\
\text { Taqman }\end{array}$ \\
\hline
\end{tabular}

$\begin{array}{llll}\text { ARICO et al., DC pulsadas com } & \begin{array}{l}\text { genes envolvidos no controle celular } \\ \text { (proliferação, diferenciação, }\end{array} & \text { Microarray } \\ \text { partículas } & \text { se05; } & \text { HIV-1 } & \text { Pr55gag } \\ \text { BUONAGURO } & \begin{array}{l}\text { migração e homeostase), } \\ \text { apresentação de antígeno (B2 } \\ \text { et al., 2008 }\end{array} & \begin{array}{l}\text { microglobulina) e ativação de } \\ \text { células T (IFN- } \gamma, \text { IL-18). }\end{array} & \end{array}$

Dentre esses estudos, o grupo de Torri identificou um perfil de expressão de DC murinas ativadas com estímulos pró-inflamatórios (TORRI et al., 2010) caracterizado pelos genes IL6, IL12B, IL1B, CCL22, CD40, CD83, CD86, ICAM1, CCR7, STAT5A, IRF8 (Affymetrix mouse MG-U74Av2 GeneChip). Tuana e colaboradores (TUANA et al., 2011) reportaram que os genes $I L 12 B, C D 40$ e SOCS3 são informativos para identificar uma DC inflamada em camundongo (Affymetrix mouse array).

Liu e colaboradores avaliaram a expressão de DC humanas imaturas ou pulsadas com antígenos tumorais por meio de microarray "whole-genome" (Illumina human HT12-v3) com 
o objetivo de determinar um perfil genético das DC que poderia ser utilizado para prever a capacidade de resposta a estímulos tumorais. Os resultados mostraram que as DC podem ser divididas em dois grupos, com base na sua capacidade de aumentar os marcadores coestimuladores e de desencadear respostas de células T. O perfil de uma DC de qualidade seria caracterizado por uma expressão diferencial de genes envolvidos na resposta imune inata e inflamatória, como os TLRs, e na apresentação do antígeno aos linfócitos T CD4+, como MHC de classe II.

Análises transcricionais de células alvos (TCD4, macrófagos) além de outras células (NK, linfócito B, DC) do HIV-1 revelaram a intensa modulação de genes envolvidos na desregulação imune, susceptibilidade à apoptose, replicação e persistência viral quando submetidas in vitro ou in vivo à exposição pelo HIV-1 ou por suas proteínas acessórias, colaborando no entendimento da correlação funcional da modulação genética na patogênese do HIV-1 in vivo (GIRI et al., 2006).

Os efeitos do HIV-1 na maturação das DC são controversos, com vários dados conflitantes na literatura.

O nosso grupo recentemente demonstrou que as DC diferenciadas a partir de monócitos de pacientes infectados pelo HIV apresentam um perfil de inflamação crônica com uma elevada expressão basal de componentes do inflamassoma e de $I L-1 \beta$, entretanto pouco responsivo ao pulso com HIV inativado (PONTILLO; SILVA; et al., 2012). Considerando o papel importante do inflamassoma e da IL-1ß na ativação das DC, este dado enfatizou a condição inflamatória dos pacientes HIV+, abrindo a questão sobre a utilização destas células em protocolos de imunoterapia.

Genes que codificam fatores de transcrição, fatores relacionados à apoptose, proteínas induzidas por estresse e proteínas antivirais foram descritos como diferencialmente expressos em DC imaturas tratadas com HIV ou transfectadas com o vetor adeno-Tat revelando um novo papel da proteína Tat na reprogramação da expressão genética que favorece a expansão da infecção viral (Affymetrix HU6800 array) (IZMAILOVA et al., 2003).

Alguns pesquisadores (ARICO et al., 2005; BUONAGURO et al., 2008) avaliaram o efeito das partículas semelhantes ao vírus HIV-1 Pr55gag (HIV-VLPs) sobre o perfil transcricional das DC, mostrando que elas são capazes de ativar as DC ao estimular a expressão de genes envolvidos no controle celular (proliferação, diferenciação, migração e homeostase), assim como na apresentação de antígeno (ß2 microglobulina) e ativação de células T $(I F N-\gamma, I L-18)$.

Genes que codificam marcadores de maturação de DC são aqueles mais 
diferencialmente expressos nas DC tratadas com HIV-1 vivo ou inativado com aldrithiol-2. O HIV-1 vivo estimularia mudanças maiores na expressão superficial dos marcadores de maturação quando comparado ao HIV-1 inativado. Provavelmente o HIV-1 inicia a maturação das DC o que pode agilizar uma transferência do vírus para os linfócitos T (HARMAN et al., 2006). Além disso, dependendo da via de infecção do HIV-1 (endocitose ou replicação intracelular) o perfil de expressão gênica na DC é diferente (HARMAN et al., 2009).

No contexto de uma vacina terapêutica aplicada a pacientes HIV+ vale salientar que até o presente nenhum estudo focou a atenção na caracterização de um perfil transcriptômico das DC, sobretudo em relação à resposta ao tratamento. Do mesmo modo, a literatura carece de uma avaliação das diferenças de expressão gênica em leucócitos circulantes antes e após a vacina.

Logo a hipótese principal do trabalho é se o perfil imunogenético de um indivíduo HIV+ pode afetar, conjuntamente a outros fatores (virais, ambientais), a resposta do mesmo à vacina terapêutica contra HIV-1. O aprofundamento destes aspectos, além de ser importante para a patogênese da infecção, é de grande interesse para identificar alguns marcadores genéticos de resposta à vacina. Sendo assim, os produtos deste trabalho serão de alta relevância e espera-se ao final comprovar a hipótese principal e, com isso, gerar subsídios técnicos necessários para a identificação e validação de marcadores genéticos de resposta à vacina terapêutica contra o HIV-1. Este trabalho poderá contribuir para o esclarecimento de alguns aspectos da resposta à vacina que ainda não foram investigados, e fornecer informações adicionais no contexto dos outros projetos em desenvolvimento no nosso laboratório em colaboração com o grupo coordenado pela Dra. Telma Oshiro, sob chefia do Prof. Alberto Duarte do laboratório LIM-56 da Faculdade de Medicina da USP. 


\section{OBJETIVOS}

\subsection{Geral}

Avaliar a contribuição do perfil genético em pacientes HIV+ submetidos à imunoterapia no ensaio de fase I/II (FMUSP) e relacionar estes aspectos com a resposta ao tratamento.

\subsection{Específicos}

1 Avaliar a expressão de genes envolvidos na resposta a HIV-1 durante as etapas de diferenciação in vitro de monócitos-DC;

2 Avaliar a expressão de genes envolvidos na resposta ao HIV-1 e/ou a resposta à vacina em leucócitos isolados antes e após o tratamento;

3 Replicar o estudo de associação entre os polimorfismos nos genes de restrição ao HIV e a resposta à imunoterapia no ensaio de fase I/II. 


\section{MATERIAIS E MÉTODOS}

\subsection{Casuística do ensaio clínico de imunoterapia}

No desenvolvimento desse trabalho foi utilizado o material biológico dos pacientes cronicamente infectados pelo HIV-1 submetidos à imunoterapia de acordo com o ensaio clínico de fase I/II e desenvolvido entre 2013 e 2014 no Laboratório de Investigação em Dermatologia e Imunodeficiências (LIM-56) da Faculdade de Medicina da Universidade de São Paulo (FMUSP).

Resumidamente, 19 pacientes adultos e soropositivos (HIV+) há no mínimo 5 anos foram selecionados para submeter-se à imunoterapia. Como critério de inclusão deveriam apresentar contagem de células T CD4+ acima de 350 células/ $\mu 1$ e carga viral plasmática (CVP) acima de 1000 cópias/ mL, sem variação significativa (25\% do número absoluto de células T CD4+ e > $0.5 \log 10(\mathrm{CVP})$ nos 6 meses anteriores à imunoterapia. Além disso, os pacientes deveriam ser virgens de tratamento antirretroviral. Foram excluídos do ensaio clínico mulheres grávidas, indivíduos com neoplasias ou infecções oportunistas até 6 meses antes, doenças autoimunes e imunodeficiências primárias. Os indivíduos selecionados foram submetidos à aférese para obtenção de uma quantidade de leucócitos suficiente tanto para o cultivo do vírus autólogo quanto para a preparação das DC do produto vacinal. Em seguida, as células mononucleadas do sangue periférico (PBMC, do inglês, Peripheral Blood Mononuclear cells) foram separadas por meio de gradiente de densidade com Ficoll/Paque ${ }^{\mathrm{TM}}$ (GE Healthcare, Inglaterra) congeladas em $90 \%$ de SBF e 10\% de DMSO e posteriormente guardadas em nitrogênio líquido até o momento de serem utilizadas para obtenção in vitro das DC do produto vacinal.

Os 19 pacientes foram randomizados em 3 grupos, de acordo com a dose ou o tipo de DC administrada, sendo:

- grupo 1: $3 \times 10^{7}$ DC (grupo controle, inexistente no ensaio anterior (LU et al., 2004))

- grupo 2: $3 \times 10^{6}$ DC pulsadas com HIV-1 (inexistente no ensaio anterior (LU et al., 2004))

- grupo 3: 3 x 107 DC pulsadas com HIV-1 (réplica do ensaio anterior (LU et al., 2004))

A dose indicada para cada grupo foi administrada 3 vezes num intervalo de 2 semanas.

Os pacientes tratados foram acompanhados por até 6 meses após a aplicação da primeira dose. Os pacientes que tiveram que iniciar o tratamento antirretroviral devido a queda na contagem de CD4+ foram excluídos do estudo. 
Os indivíduos incluídos na imunoterapia são pacientes acompanhados no Ambulatório ADEE - 3002 do Departamento de Dermatologia do Hospital das Clínicas da FMUSP.

\subsection{Desenho do estudo}

No desenho do estudo geral (figura 1), os focos de análises consistiam tanto no material utilizado na preparação da vacina terapêutica (monócitos e células dendríticas da etapa de manipulação in vitro) quanto nos PBMC isolados dos pacientes incluídos no ensaio clínico de fase I/II antes e após a administração da vacina, assim como a genotipagem de polimorfismos nos genes de restrição do HIV ou nos genes previamente associados à resposta a imunoterapia.

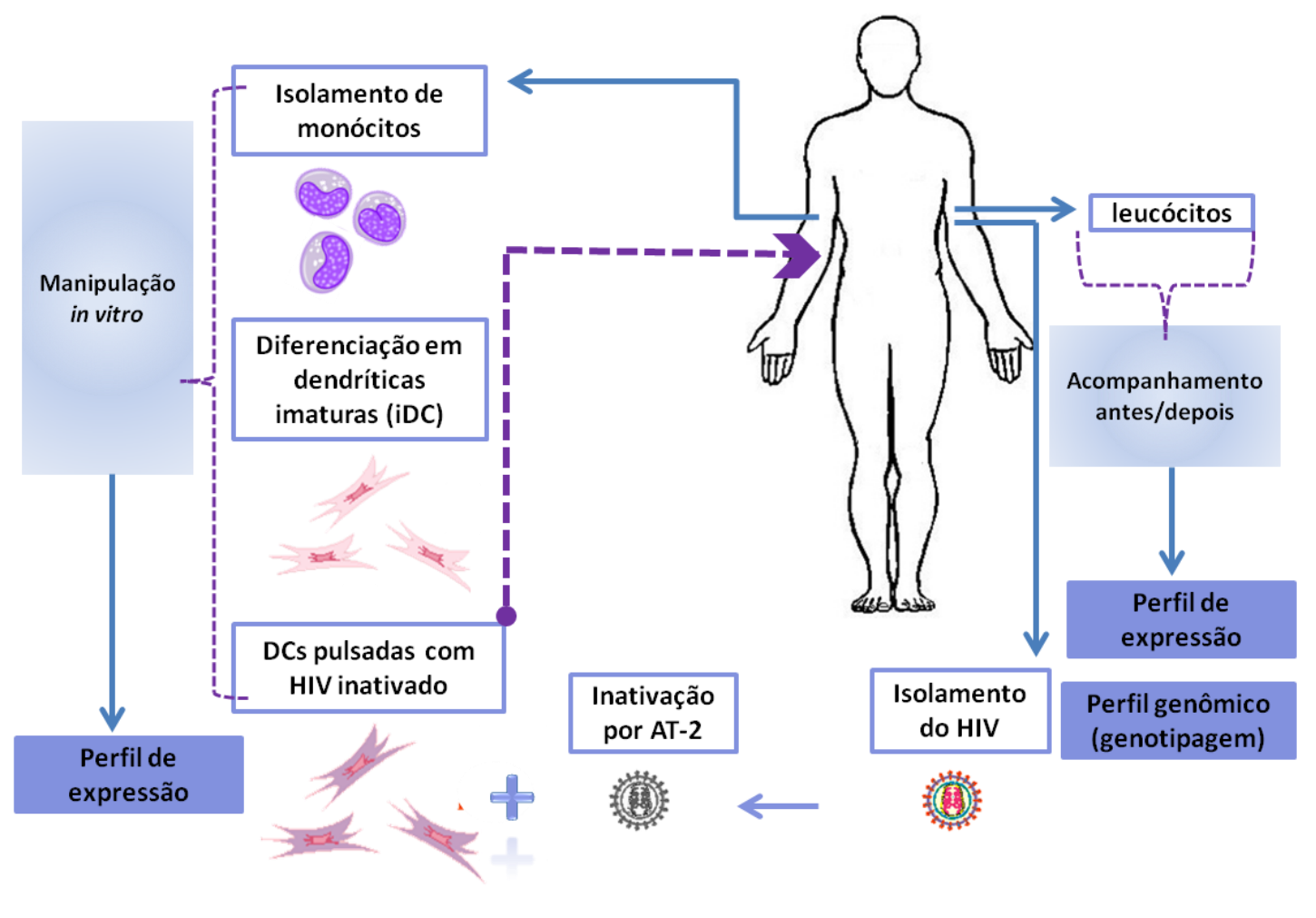

Figura 1 - Representação esquemática do trabalho. Os 19 pacientes foram classificados em 3 grupos, de acordo com a dose de vacina recebida/não. Foi feito para cada paciente o isolamento de monócitos para a diferenciação de DC e o isolamento do HIV do paciente para pulso das DC com o vírus inativado por AT-2 (aldrithiol-2). Em seguida foi visto o perfil de expressão para todas as etapas de manipulação in vitro. Por fim, a coleta de leucócitos dos pacientes antes e durante o seguimento vacinal para ver o perfil de expressão e análise do perfil genômico. Esses resultados foram correlacionados com a resposta à imunoterapia dos pacientes (bom e mau respondedor). 


\subsection{Casuística utilizada nesse projeto}

Dos 19 pacientes submetidos à vacina terapêutica, quatro foram excluídos ao longo do acompanhamento e os dois controles (grupo 1) não representavam interesse em relação ao nosso estudo. Dos 13 indivíduos tratados que completaram o acompanhamento, tivemos a oportunidade de avaliar a expressão gênica e a frequência de polimorfismos selecionados em 11 (Figura 2). O presente projeto foi submetido e aprovado pelo Comitê de Ética em Pesquisas com Seres Humanos do Instituto de Ciências Biomédicas da Universidade de São Paulo (Parecer 1150/CEP) e pela Comissão de Ética para Análise de Projetos de Pesquisa do HCFMUSP CAPPesq (0791/09).

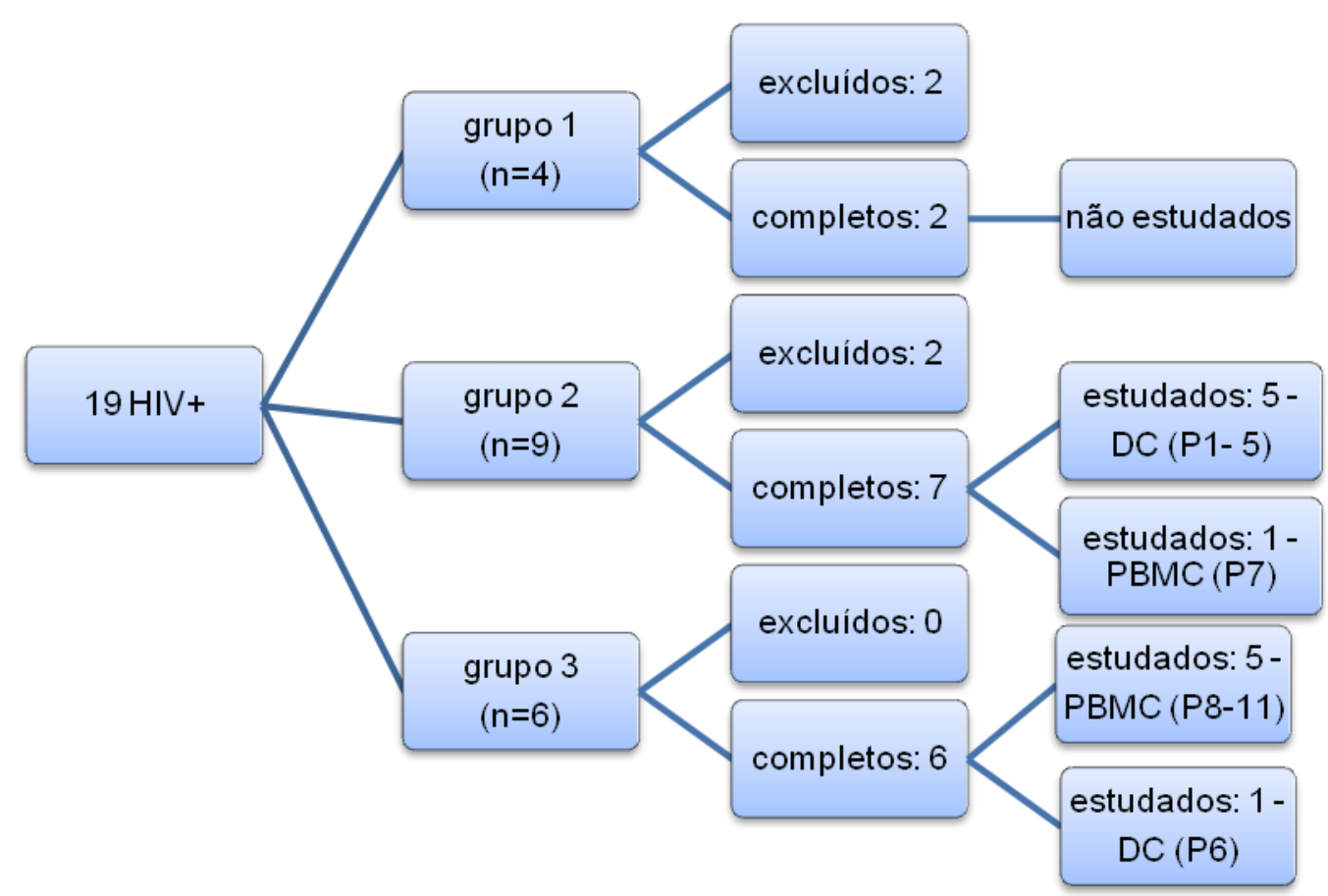

Figura 2 - Esquema dos pacientes HIV+ incluídos no ensaio clínico e dos indivíduos estudados nesse trabalho

Os PBMC derivados de 6 pacientes (P1-P6) foram utilizados para o estudo de expressão gênica durante o protocolo de diferenciação monócitos-DC (objetivo 1 - resultados parte I). Esses indivíduos foram selecionados com base na disponibilidade de material biológico, sendo que a demanda de PBMC para obtenção do produto vacinal foi grande e o rendimento da aférese muito variável entre os pacientes.

Os PBMC de 6 pacientes (P6-P11) coletados antes e após a vacina, foram utilizados para o estudo da expressão gênica de resposta à vacina (objetivo 2 - resultados parte II). 
Nesse caso, foram selecionados pacientes que teoricamente poderiam ter mais chance de responder ao tratamento (grupo 3: P6, P8-P11) ou que estavam respondendo ao tratamento após as primeiras semanas da vacina (P7 do grupo 2).

O DNA genômico dos 11 pacientes (P1-P11) foi isolado a partir dos PBMC coletados antes do tratamento.

Os dados demográficos (idade, sexo) e clínicos principais (CVP, contagem de linfócitos T CD4+ e CD8+) dos pacientes estudados são reportados na tabela 3.

Tabela 3 - Dados demográficos e clínicos dos pacientes HIV+ estudados

\begin{tabular}{c|c|c|c|c|c|c}
\hline PACIENTE & GRUPO & IDADE & SEXO & $\begin{array}{c}\text { CVP } \\
\text { (cópias de RNA/ mL; } \\
\left.\log _{10}(\mathrm{CVP})\right)\end{array}$ & $\begin{array}{c}\text { CD4+ } \\
\text { (células/ } \mu \mathrm{l})\end{array}$ & $\begin{array}{c}\text { CD8+ } \\
\text { (células/ } \mu 1)\end{array}$ \\
\hline P1 & 2 & 40 & $\mathrm{M}$ & $21420 ; 4.3$ & 566 & 776 \\
\hline P2 & 2 & 35 & $\mathrm{M}$ & $38295 ; 4.6$ & 500 & 1100 \\
\hline P3 & 2 & 27 & $\mathrm{M}$ & $5003 ; 3.7$ & 502 & 1139 \\
\hline P4 & 2 & 24 & $\mathrm{M}$ & $24530 ; 4.4$ & 569 & 868 \\
\hline P6 & 2 & 23 & $\mathrm{M}$ & $1342 ; 3.1$ & 684 & 822 \\
\hline P7 & 2 & 39 & $\mathrm{~F}$ & $3429 ; 3,5$ & 480 & 1371 \\
\hline P8 & 3 & 30 & $\mathrm{M}$ & $5121 ; 3.7$ & 353 & 877 \\
\hline P9 & 3 & 38 & $\mathrm{M}$ & $59152 ; 4.8$ & 471 & 1212 \\
\hline P10 & 3 & 35 & F & $16168 ; 4.2$ & 580 & 1536 \\
\hline P11 & 3 & 30 & M & $15789 ; 4.2$ & 423 & 785 \\
\hline
\end{tabular}

Abreviações: $\mathrm{M}=$ masculino, $\mathrm{F}=$ feminino; $\mathrm{CVP}=$ carga viral plasmática; $\mathrm{CD} 4+=$ linfócitos $\mathrm{T}$ CD4+; CD8+= linfócitos T CD8+.

Os dados relacionados com a variação de CVP e de níveis plasmáticos de linfócitos T CD4+ e CD8+ após a imunoterapia são reportados na tabela 4. 
Tabela 4- Diferenças de CVP e dos níveis de linfócitos T após a imunoterapia

\begin{tabular}{|c|c|c|c|c|c|c|c|c|c|c|c|}
\hline \multirow{2}{*}{$\begin{array}{c}\text { Tempos } \\
\text { após o tratamento/ } \\
\text { Dados clínicos }\end{array}$} & \multicolumn{11}{|c|}{ Pacientes HIV+ } \\
\hline & P1 & $\mathbf{P 2}$ & P3 & P4 & P5 & P6 & P7 & P8 & P9 & P10 & P11 \\
\hline t1- 15 dias & & & & & & & & & & & \\
\hline$\Delta \mathrm{CVP}\left(\log _{10}(\mathrm{CVP})\right)$ & 0,24 & 0,04 & 0,2 & 0,14 & 0,19 & 0,32 & $-0,42$ & $-0,41$ & 0,01 & 0,43 & $-0,08$ \\
\hline$\Delta \mathrm{CD} 4+($ células $/ \mu \mathrm{l})$ & -156 & -103 & -40 & -213 & 50 & -100 & 125 & 17 & 106 & 36 & -82 \\
\hline$\Delta \mathrm{CD} 8+($ células $/ \mu \mathrm{l})$ & -144 & -260 & -64 & -237 & 94 & -257 & 213 & 2 & 160 & 163 & -26 \\
\hline t2- 30 dias & & & & & & & & & & & \\
\hline$\Delta \mathrm{CVP}\left(\log _{10}(\mathrm{CVP})\right)$ & 0,23 & $-0,15$ & 0,04 & $-0,04$ & 0,64 & 0,08 & $-1,09$ & $-0,39$ & $-0,38$ & 0,38 & 0,58 \\
\hline$\Delta$ CD4+ (células/ $\mu \mathrm{l})$ & -94 & -233 & -14 & -138 & 96 & -138 & 162 & -86 & 113 & -82 & -5 \\
\hline$\Delta \mathrm{CD} 8+($ células/ $\mu \mathrm{l})$ & -208 & -402 & -152 & -159 & 140 & -343 & 201 & -50 & 33 & -281 & 25 \\
\hline$t 3-45$ dias & & & & & & & & & & & \\
\hline$\Delta \mathrm{CVP}\left(\log _{10}(\mathrm{CVP})\right)$ & 0,32 & 0,03 & 0,2 & 0,64 & 0,24 & $-0,02$ & $-1,49$ & $-0,74$ & $-0,35$ & 0,24 & 0,46 \\
\hline$\Delta \mathrm{CD} 4+($ células $/ \mu \mathrm{l})$ & -24 & -204 & -32 & -196 & 103 & -86 & 133 & -67 & 9 & 63 & 6 \\
\hline$\Delta \mathrm{CD} 8+($ células $/ \mu \mathrm{l})$ & -23 & -354 & -176 & -219 & 181 & -185 & 468 & 32 & -81 & 48 & 32 \\
\hline 2 meses & & & & & & & & & & & \\
\hline$\Delta \mathrm{CVP}\left(\log _{10}(\mathrm{CVP})\right)$ & 0,33 & $-0,13$ & 0,13 & $-0,04$ & 0,03 & 0,13 & $-1,46$ & - & $-0,04$ & 0,43 & 0,83 \\
\hline$\Delta \mathrm{CD} 4+($ células/ $\mu \mathrm{l})$ & -66 & -237 & 88 & -163 & 117 & -60 & 111 & -376 & 74 & 44 & -33 \\
\hline$\Delta \mathrm{CD} 8+($ células $/ \mu \mathrm{l})$ & -123 & -442 & 150 & 58 & 332 & -221 & 86 & -490 & -147 & -35 & 40 \\
\hline 6 meses & & & & & & & & & & & \\
\hline$\Delta \mathrm{CVP}\left(\log _{10}(\mathrm{CVP})\right)$ & 0,46 & $-0,05$ & 0,02 & $-0,13$ & $-0,2$ & 0,18 & $-3,83$ & $-0,24$ & $-0,08$ & 0,39 & 0,44 \\
\hline$\Delta \mathrm{CD} 4+($ células $/ \mu \mathrm{l})$ & 67 & -87 & 57 & -125 & 69 & -69 & 267 & 12 & -235 & 49 & 33 \\
\hline$\Delta \mathrm{CD} 8+($ células $/ \mu \mathrm{l})$ & 109 & -163 & -89 & 10 & -39 & -422 & -71 & 105 & -869 & 78 & 63 \\
\hline
\end{tabular}

Abreviações: $\triangle \mathrm{CVP}=$ diferença da carga viral plasmática de $\mathrm{t} 1, \mathrm{t} 2, \mathrm{t} 3, \mathrm{t} 4, \mathrm{t} 5, \mathrm{t} 6-\mathrm{t} 0 ; \Delta \mathrm{CD} 4+=$ diferença da contagem de linfócitos $\mathrm{T}$ CD4+ de t1, t2, t3, t4, t5, t6 - t0; $\Delta \mathrm{CD} 8+=$ diferença da contagem de linfócitos T CD8+ de t1, t2, t3, t4, t5, t6 - t0;

\subsection{Obtenção de vírus HIV-1 inativado}

A obtenção de vírus inativado por aldrithiol-2 (AT-2, Sigma-Aldrich, MO, EUA) foi realizada conforme protocolo descrito na literatura, a fim de se preservar intacta a conformação nativa do vírus e a atividade da gp120 em se fundir à célula (LU et al., 2004; ROSSIO et al., 1998). Para isso, os PBMC dos pacientes HIV+ foram estimulados com fitohemaglutinina e IL-2 e co-cultivados com células T CD4+ do mesmo indivíduo, previamente depletados de células T CD8+. Os isolados virais foram inativados com $250 \mu \mathrm{M}$ de AT-2 por 1 hora a $37^{\circ} \mathrm{C}$. 


\subsection{Obtenção de monócitos e células dendríticas derivadas de monócitos}

Os monócitos foram obtidos a partir de PBMC dos pacientes HIV+ (previamente isolados por aférese e congelados) por adesão em placa de cultura por $2 \mathrm{~h}$ e, após lavagem, cultivados a $1.5-2 \times 10^{6} / \mathrm{ml}$ em meio de cultura AIM-V (Gibco, Life Technologies, EUA). A diferenciação em DC foi obtida com cultivo dos monócitos em AIM-V na presença de 50 ng/ mL de IL-4 (Cell Genix, EUA) e $50 \mathrm{ng} / \mathrm{mL}$ de GM-CSF (Cell Genix) por 5 dias. No $5^{\circ}$ dia de cultura as DC imaturas (iDC) foram pulsadas com HIV-1 inativado ( 1 x $10^{9}$ partículas virais/30 x $10^{6}$ células) por 4 horas. As DC pulsadas (4 h - DC) foram lavadas para retirar o vírus em excesso e incubadas na presença do "coquetel de maturação" (IL-4 50 ng/ mL, GMCSF $50 \mathrm{ng} / \mathrm{mL}$, TNF $50 \mathrm{ng} / \mathrm{mL}$, IL-1ß $10 \mathrm{ng} / \mathrm{mL}$, IL-6 $100 \mathrm{ng} / \mathrm{mL}$ ) (Cell Genix) por 10 horas (14 h - DC), 20 horas (24 h - DC) ou 44 horas (48 h - DC). As DC maduras, ou seja, as $48 \mathrm{~h}$ - DC representam o produto vacinal.

Em 6 momentos ao longo da diferenciação de monócitos a DC (monócitos, iDC, 4 h, 14 h , 24 h, 48 h - DC), as células foram utilizadas para a análise da expressão gênica e para os ensaios de caracterização fenotípica e funcional.

\subsection{Obtenção de PBMC para estudo da resposta à imunoterapia}

Foram utilizadas de cada um 6 pacientes, 4 alíquotas de PBMC isolados e congelados a partir de amostras de sangue coletadas antes e durante o ensaio clínico para análise de expressão gênica em resposta à imunoterapia. Essas amostras foram coletadas antes do tratamento (t0), após 15 dias da primeira dose (t1), após 30 dias da primeira dose e pouco antes da segunda dose (t2), após 45 dias da primeira dose e logo antes da terceira dose (t3).

\subsection{Isolamento de RNA e retrotranscrição}

O RNA total foi isolado das células utilizando o RNAeasy ${ }^{\circledR}$ mini kit (Qiagen, EUA) de acordo com as instruções do fabricante. A pureza e quantidade do RNA foram avaliadas por meio de leitura por espectrofotometria (Thermo Scientific Nanodrop, EUA). Em seguida, 1 $\mu \mathrm{g}$ de RNA total de cada amostra foi retrotranscrito utilizando o kit RT2 PreAMP cDNA Synthesis Kit (Qiagen), de acordo com as instruções do fabricante. Após a síntese do cDNA, o produto foi pré-amplificado através de uma mistura de primers em acordo com o grupo de genes a serem amplificados nos arranjos utilizados nos experimentos. 


\subsection{Avaliação da expressão gênica durante a diferenciação monócitos-células dendríticas}

Foram avaliados 84 genes envolvidos na resposta anti-HIV do hospedeiro por meio de PCR em tempo real utilizando um arranjo comercial (RT2 Profiler PCR "Host Genome AntiHIV" Array; PAHS-051Y (Qiagen) e o equipamento de PCR em tempo real ABI 7300 (Applied Biosystems, EUA). Os 84 genes desse arranjo compreendem tanto genes de restrição para o HIV-1 quanto genes da imunidade previamente descritos como associados à resposta do hospedeiro ao HIV-1, mais 5 genes housekeeping (controles endógenos), 1 controle de contaminação de DNA genômico (HGDC), 3 controles de atividade da transcrição reversa (RTC) e 3 controles positivos da amplificação PCR (PPC). A lista completa dos genes e as informações detalhadas sobre cada gene estão listadas no anexo A. Após a amplificação, o software ABI 7300 SDS (Applied Biosystems) foi utilizado para obter os dados de cycle threshold $(\mathrm{Ct})$ para cada gene utilizado na análise comparativa de expressão gênica. Os dados de $\mathrm{Ct}>35$ foram excluídos da análise.

Os dados de expressão dos genes foram analisados usando o método comparativo de $\mathrm{Ct}$, proposto por (SCHMITTGEN; LIVAK, 2008). Para normalização dos dados de Ct ( $\Delta \mathrm{Ct}$ ) foi utilizado um valor médio dos genes housekeeping ((ACTB (ß-actina), B2M (B-2microglobulina), GAPDH (glyceraldehyde-3-phosphate dehydrogenase), HPRT1 (hypoxanthine phosphoribosyl-transferase 1) e RPLPO (ribosomal protein large P0) para cada experimento. As comparações para avaliação da modulação gênica (do inglês, Fold change , $F C$ ) foram feitas entre as etapas de diferenciação de DC e os monócitos (comparações

pareadas, $2^{-\Delta \Delta \mathrm{Ct}}$ ), ou entre as células do agrupamento hierárquico (comparação entre médias, $\left.2^{-\Delta \mathrm{Ct}} / 2^{-\Delta \mathrm{Ct}}\right)$. O teste $\mathrm{t}$ foi utilizado para avaliar a significância da modulação de expressão gênica entre os grupos analisados. Nos gráficos e nas análises de agrupamento hierárquico foram utilizados os dados como $\log _{2} \mathrm{FC}$.

\subsection{Análise da expressão gênica em resposta à imunoterapia}

Para o perfil de expressão relativo a resposta dos pacientes à imunoterapia foi customizado pelo nosso laboratório um arranjo de genes com tecnologia $\mathrm{RT}^{2}$ PCR Profiler (Custom Human PCR CAPH12563, Qiagen), contendo 86 genes alvos, mais 3 genes housekeeping (ACTB, GAPDH, HPRT1), 1 controle de contaminação de DNA genômico (HGDC), 3 controles de atividade da transcrição reversa (RTC) e 3 controles positivos da amplificação PCR (PPC). O esquema representativo encontra-se abaixo (figura 3) e a lista 
detalhada dos genes encontra-se no anexo B.

\begin{tabular}{|c|c|c|c|c|c|c|c|c|c|c|c|c|}
\hline & 1 & 2 & 3 & 4 & 5 & 6 & 7 & 8 & 9 & 10 & 11 & 12 \\
\hline A & APOBEC3G & BAX & BCL2 & BST2 & CASP1 & CASP3 & CCL19 & CCL2 & CCL20 & CCL3 & CCL4 & CCL5 \\
\hline B & CCR5 & CCR6 & CCR7 & CD127 & CD14 & CD16 & $\mathrm{CD} 25$ & CD27 & CD38 & CD40L & CD45RO & CD56 \\
\hline C & CD69 & CNOT1 & CTLA-4 & CXCL10 & CXCL11 & CXCL12 & CXCL9 & CXCR5 & EOMES & FAS & FASL & FOXP3 \\
\hline D & GATA3 & GZMA & GZMB & ICOS & IDO & IFI16 & IFNA1 & IFNG & IL10 & IL13 & IL15 & IL17 \\
\hline $\mathbf{E}$ & IL1A & IL1B & IL22 & IL23A & IL27 & IL4 & IL5 & IL6 & IL7 & IL8 & IRF3 & IRF7 \\
\hline $\mathbf{F}$ & ISG15 & KIR3DL1 & KIR3DS1 & LAG3 & LAMP1 & Mx1 & Myd88 & NKG2D & NKp44L & OAS1 & PARD3B & PD1 \\
\hline G & PDL1 & PPIA & PRF1 & RORC & SLFN11 & STAT1 & TAP1 & TBET & TGFB & TIM3 & TNF & TNFSF10 \\
\hline H & TRIM5 & XIAP & ACTB & GAPDH & HPRT1 & HGDC & RTC & RTC & RTC & PPC & PPC & PPC \\
\hline
\end{tabular}

Figura 3 - Esquema representativo da placa utilizada para análise de expressão gênica em resposta à imunoterapia. São mostrados 86 genes de estudo. Também são representados os genes housekeeping (ACTB, GAPDH e HPRT1), o controle de contaminação com DNA genômico (HGDC), os controles da transcrição reversa (RTC) e os controles positivos (PPC).

A escolha dos 86 genes incluídos no arranjo baseou-se na literatura disponível quanto a resposta de PBMC a vacinas profiláticas anti-HIV-1 (DE GOEDE et al., 2015) ou a resposta genérica a desafio vacinal (HARALAMBIEVA et al., 2012; SCHERER et al., 2007; WOLF et al., 2012) ou a dados genéticos publicados pelo nosso grupo de pesquisa na fase I do mesmo ensaio clínico em estudo (MOURA et al., 2014; PONTILLO et al., 2014; SEGAT et al., 2010). Um resumo dos genes e das referências utilizadas na seleção são reportados na tabela 5 .

Os dados de expressão dos genes foram analisados usando o método comparativo de $\mathrm{Ct}$ (SCHMITTGEN; LIVAK, 2008) como descrito anteriormente.

Para normalização $(\Delta \mathrm{Ct})$ foi utilizado um valor médio dos 3 genes housekeeping para cada experimento. As comparações para avaliação da modulação gênica (FC) foram feitas entre as etapas de acompanhamento (t1, t2, t3) e os PBMC antes da terapia (t0) (comparações pareadas, $\left.2^{-\Delta \Delta \mathrm{Ct}}\right)$. Nos gráficos e na análise de agrupamento hierárquico foram utilizados os dados como $\log _{2}$ FC. 
Tabela 5- Genes selecionados para customização do arranjo de genes RT $^{2}$ PCR Profiler (Custom Human PCR CAPH12563, Qiagen)

\begin{tabular}{|c|c|}
\hline FUNÇÕES & GENES E REFERÊNCIAS \\
\hline \multicolumn{2}{|l|}{ Marcadores de PBMC } \\
\hline Monócitos & CD14, CD16, IL1A, IL1B \\
\hline Linfócitos Th1 & TBET, IFNG; IL27 (SOGHOIAN et al., 2012) \\
\hline Linfócitos Th2 & IL13, IL4, IL5, IL10, TGFB; GATA3(VETTER et al., 2009) \\
\hline Linfócitos Th17 & CCR6, IL17, IL122, IL23A, RORC \\
\hline Linfócitos Treg & FOXP3, IL10, TGFB \\
\hline Linfócitos T citotóxicos & GZMB, LAMP1, PRF1; GZMA(SOGHOIAN et al., 2012) \\
\hline Linfócitos $\mathrm{T}$ foliculares & CCR6, CXCR5, ICOS, PD1(LARSSON et al., 2013) \\
\hline Linfócitos T de memória central & CD27, CD45RO, CCR7(SENNEPIN et al., 2013) \\
\hline Células NK & $\begin{array}{l}\text { CD16, CD107A, KIR3DL1, KIR3DS1, IFNG, NKG2D, } \\
\text { NKp44L(SENNEPIN et al., 2013) }\end{array}$ \\
\hline $\begin{array}{l}\text { Moléculas linfocitárias associadas } \\
\text { a resposta à vacina }\end{array}$ & $\begin{array}{l}\text { CD38, CD69, FOXP3; CD25(RODRIGUEZ et al., 2014); } \\
\text { CD40L(KORNBLUTH, 2000), }\end{array}$ \\
\hline Marcadores de exaustão imune & $\begin{array}{l}\text { CD38; CTLA-4(LARSSON et al., 2013), PD1, CD69, } \\
\text { TIM3(POONIA; PAUZA, 2014), }\end{array}$ \\
\hline $\begin{array}{l}\text { Proteínas ou genes modulados em } \\
\text { resposta a vacinas }\end{array}$ & $\begin{array}{l}\text { OAS1, MX, STAT1,TAP1 e IRF7 (ROTGER et al., 2010), } \\
\text { CCL20 (FONTAINE; POUDRIER; ROGER, 2011), TNF, } \\
\text { IL6, IL23A, IFNA1, FASL, GZMB, TNFSF10, } \\
\text { EOMES(POONIA; PAUZA, 2014), ISG15 (RAPOSO et al., } \\
\text { 2013) }\end{array}$ \\
\hline Resposta polifuncional & CD25, CCLA, IFNG, TNF \\
\hline Receptores e ligantes do HIV-1 & $\begin{array}{l}\text { CCL5, CCR5, CXCL12/SDF1; CCL2 e CCL4 (SAMSON et } \\
\text { al., 1996); }\end{array}$ \\
\hline $\begin{array}{l}\text { Fatores de restrição para HIV-1 } \\
\text { relacionados com resposta à vacina }\end{array}$ & $\begin{array}{l}\text { APOBEC3G (RAPOSO et al., 2013); BST2 (RAPOSO et al., } \\
\text { 2013); PARD3B (PONTILLO et al., 2014); PPIA, SLFN11, } \\
\text { TRIM5 (RAPOSO et al., 2013) }\end{array}$ \\
\hline Apoptose & BAX, BCL2, CASP3, CD40L, FAS, FASL, XIAP, TNFSF10 \\
\hline Piroptose induzida por HIV-1 & CASP1, IFI16 (NISSEN et al., 2014) \\
\hline $\begin{array}{l}\text { Quimiocinas relacionados com } \\
\text { resposta à vacina }\end{array}$ & $\begin{array}{l}\text { IL8, CCR7, CXCL10, CXCL10, CXCL11, CXCL12, } \\
\text { CXCL9(FONTAINE et al., 2011); CXCR5(BOSWELL et al., } \\
\text { 2014) }\end{array}$ \\
\hline $\begin{array}{l}\text { Outros genes relacionados com } \\
\text { resposta à vacina }\end{array}$ & $\begin{array}{l}\text { CNOT1 (MOURA et al., 2014), IL7 (TANASKOVIC et al., } \\
\text { 2014), LAG3 (PENA et al., 2014) }\end{array}$ \\
\hline
\end{tabular}

3.10 Avaliação da expressão gênica com sondas fluorogênicas gene-específicas e tecnologia Taqman

Os genes NLRP3, CASP1, IL18, NOS1 e MBL2, foram amplificados com sondas fluorogênicas gene-específicas e tecnologia TaqMan (Applied Biosystems) na plataforma ABI 7300 SDS (Applied Biosystems). A análise dos dados obtidos foi avaliada em acordo com Scmitten e Livak (SCHMITTGEN; LIVAK, 2008) como descrito acima. 


\subsection{Análise por heat map e agrupamento hierárquico}

A análise por heat map foi realizada com o intuito de verificar a associação entre o perfil de expressão gênica e as etapas de diferenciação monócitos-DC ou resposta à imunoterapia. Esse tipo de representação e o agrupamento hierárquico resultante foram obtidos através dos dados de $\log _{2}$ FC pela função heatmap.2 do pacote "gplots" na plataforma matemático-estatística $\mathrm{R}$ versão 3.1 .3 (http://www.r-project.org), utilizando-se a distância euclidiana. A Análise de Agrupamento foi realizada através do pacote "pvclust", utilizado para calcular o p-valor aproximadamente não viesado (Approximately Unbiased - AU pvalue) de cada grupo identificado. Essa abordagem permitiu determinar o nível de significância para cada agrupamento (dado não mostrado).

Os valores de $\log _{2}$ FC foram plotados de forma linear e com tons de verde ou vermelho atribuídos para cada valor, sendo que tons de verde indicam genes menos expressos e tons de vermelho indicam os mais expressos em relação à condição de comparação (monócitos pelas DC ou t0 pelos PBMC).

\subsection{Análise in silico das funções biológicas}

A ferramenta online Genemania (http://www.genemania.org/) foi usada para a análise in silico dos dados selecionados pela análise de FC. O Genemania utiliza bancos de dados públicos de co-expressão gênica como Gene Expression Omnibus (GEO), de interação física e genética como BioGRID; de predição de interação proteína-proteína como I2D, de vias de sinalização e/interação molecular, como Pathway Commons. Os resultados da análise são reportados com o respectivo valor de FDR (do inglês, False Discovery Rate).

\subsection{Genotipagem com sondas alelo-específicas e tecnologia Taqman}

O DNA genômico dos 11 pacientes estudados foi isolado das alíquotas de PBMC congeladas ao tempo t0 por meio do kit Gentra Puregene ${ }^{\circledR}$ (Qiagen) de acordo com as instruções do fabricante, e quantificado utilizando o espectrofotômetro (Nanodrop ND-1000. Thermo Scientific).

Foram analisados 22 polimorfismos em 13 genes de fatores de restrição para HIV-1 (APOBEC3G, CCL4, CCL5, CCR5, CUL5, CXCR6, HLA-C, IFNG, PARD3B, PROX1, SDF1, TRIM5, ZNRD1) enquanto associados a susceptibilidade ao HIV-1 e/ou progressão a AIDS, e 
2 polimorfismos de base única (SNP) nos genes NOS1 e MBL2 como estudo de réplica da genotipagem dos indivíduos da fase I do ensaio clínico (PONTILLO et al., 2014; SEGAT et al., 2010).

Para a genotipagem dos polimorfismos selecionados, com exceção do $\Delta 32$ de CCR5, as amostras de DNA na concentração padrão de $100 \mathrm{ng} / \mu \mathrm{l}$ foram amplificadas por meio de sondas alelo-específicas e tecnologia Taqman (Applied Biosystems) no equipamento de PCR em tempo ABI 7300 (Applied Biosystems). Após a amplificação, o software ABI 7300 SDS (Applied Biosystems) foi utilizado para a discriminação alélica. Para genotipar o polimorfismo do $\triangle 32$ de CCR5 foi utilizada RLFP-PCR.

\subsection{Avaliação fenotípica de células dendríticas}

Para avaliar a diferenciação e ativação das DC obtidas in vitro, as células iDC e 48 h DC foram analisadas por citometria de fluxo FACSCalibur (BD, Califórnia, EUA) com relação à expressão de moléculas de superfície características de DC (CD14, CD11c, HLADR), marcadores da maturação da DC (CD83, CD40) e moléculas co-estimuladoras (CD80, CD86). Foram empregados anticorpos monoclonais como marcadores de diferenciação e ativação e seus respectivos controles isotípicos (BD) de acordo com as instruções do fabricante (tabela 6). A coleta de dados foi feita em citômetro de fluxo FACSCalibur e incluiu um mínimo de 10.000 eventos determinados dentro do gate característico de tamanho e granulosidade de células dendríticas, excluindo-se a região de células mortas e seguindo a estratégia de análise descrita na figura 4. A análise dos dados empregou o programa FCS Express Version 3 (BD). 


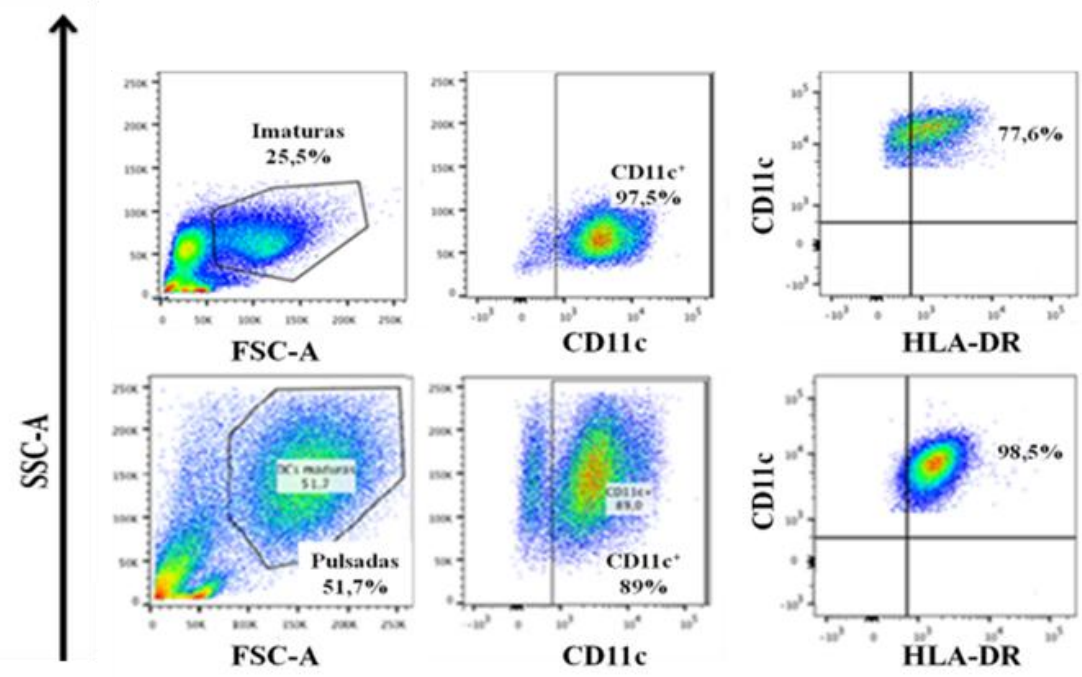

Figura 4 - Estratégia de análise dos dados de citometria de fluxo. Esquema de análise dos marcadores de superfície de iDC e $48 \mathrm{~h}$ - DC. Foi feito um gate no tamanho e granulosidade característico da célula a ser analisada. Após isso, foi selecionada a população positiva para CD11c e em cima dessa população foi vista a expressão dos outros marcadores.

Tabela 6 - Lista dos anticorpos monoclonais utilizados

\begin{tabular}{l|l|l}
\hline Especificidade & Clone & Fluorocromo \\
\hline CD14 & M5E2 & PE \\
\hline CD11c & B-ly6 & PeCy5 \\
\hline HLA-DR & L243 & FITC \\
\hline CD80 & L307.4 & PE \\
\hline CD86 & $2331($ FUN-1) & FITC \\
\hline CD40 & B-ly6 & FITC \\
\hline CD83 & HB15e & FITC \\
\hline
\end{tabular}

O teste two-way ANOVA, seguido do pós-teste de Bonferroni para grupos selecionados, foi utilizado para comparar as variáveis entre grupos diferentes. A análise estatística e os gráficos foram gerados com o auxílio do software GraphPad Prism®.(San Diego, CA, EUA). Diferenças com $\mathrm{p}<0.05$ foram consideradas significativas.

\subsection{Avaliação da viabilidade celular}

Para avaliar a viabilidade celular das DC foi utilizado o kit BD Cell Viability Kit (BD), de acordo com as instruções do fabricante. O kit contém a solução laranja de tiazol para 
marcar todas as células e iodeto de propídio para marcar apenas as células mortas, levando em consideração que as células vivas tem as membranas intactas e são impermeáveis a corantes como o iodeto de propídeo. O teste $\mathrm{t}$, foi utilizado para comparar a viabilidade entre grupos diferentes. A análise estatística e os gráficos foram gerados com o auxílio do software GraphPad Prism®. Diferenças com $\mathrm{p}<0.05$ foram consideradas significativas.

\subsection{Análise funcional das células dendríticas: ensaios de co-cultivo}

A capacidade das DC de induzir a ativação de linfócitos $\mathrm{T}$ autólogos foi avaliada por meio de ensaios de co-cultivo DC-linfócitos $\mathrm{T}$ autólogos e determinação da indução da produção de IFN- $\gamma$ nos linfócitos.

$2 \times 10^{5}$ de PBMC autólogos (células não-aderentes após adesão em placa de cultura) foram co-cultivados com $0.4 \times 10^{5} \mathrm{DC} /$ poço em uma placa de 96 poços por 96 horas. A avaliação dos linfócitos $\mathrm{T}$ produtores de IFN- $\gamma(\mathrm{IFN}+)$ foi feita através de marcação intracelular com anticorpo fluorogênico e citometria de fluxo. As células foram tratadas com $20 \mu \mathrm{g} / \mathrm{ml}$ BrefeldinA (Sigma-Aldrich) nas últimas 4 horas do período da cultura, para inibir a secreção proteica, lavadas e incubadas com anticorpos anti-CD3 marcados com PECY5 (BD). Em seguida, as células foram permeabilizadas com a solução Cytofix/Cytoperm (BD) e marcadas com o anticorpo anti-IFN- $\gamma$ marcado com PE $(B D)$. A contagem dos linfócitos $\mathrm{T}$ IFN+ foi feita no citômetro de fluxo LRS Fortessa (BD). A estratégia de gate utilizada para análise está na Figura 5.

A estimulação com a enteroxina B do estafilocos (SEB) foi usada como controle positivo. Os dados foram reportados com uma porcentagem de células IFN- $\gamma+$ CD3+e analisadas por t- test no GraphPad Prism®.

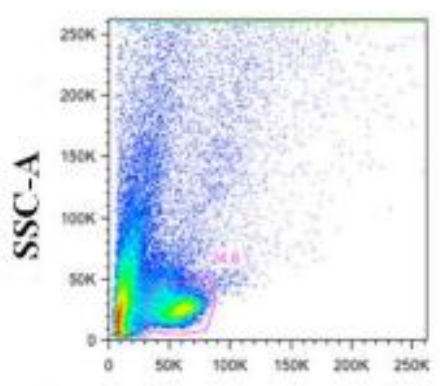

FSC-A

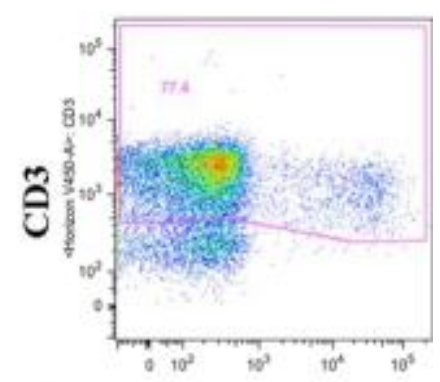

IFN- $\gamma$

Figura 5 - Estratégia de gate para definição de linfócitos T produtores de IFN- $\gamma$. A população de linfócitos foi determinada com base em SSC x FSC. Foram definidas as células CD3+. Após esta etapa, foram definidas as células produtoras de IFN- $\gamma$. A seleção de linfócitos positivos foi feita por comparação com amostras não estimuladas, ou seja, cultivadas sem a presença de DC pulsadas. 


\section{RESULTADOS E DISCUSSÃO- PARTE I}

\subsection{Análise da expressão gênica em monócitos e células dendríticas derivadas de monócitos}

A expressão relativa de genes envolvidos na resposta do hospedeiro contra o HIV-1 foi examinada nas várias etapas de diferenciação celular de monócitos em células dendríticas: monócitos, células dendríticas imaturas (iDC) e células dendríticas após a estimulação com o vírus HIV-1 inativado (AT-HIV) e coquetel de citocinas, de acordo com o protocolo do ensaio clínico, até a obtenção de células dendríticas maduras e ativadas (48 h - DC). Entre as etapas de iDC e (48 h - DC) foram escolhidos os seguintes tempos para avaliação da expressão gênica:

- após 4 horas da estimulação com AT-HIV (estimulação apenas com vírus): 4 h - DC

- após 14 horas da estimulação com AT-HIV (estimulação com vírus por 4 horas e coquetel de citocinas por mais 10 horas): $14 \mathrm{~h}$ - DC

- após 24 horas da estimulação com AT-HIV (estimulação com vírus por 4 horas e coquetel de citocinas por mais 20 horas): $24 \mathrm{~h}$ - DC

Essa escolha foi baseada na observação que os genes do ensaio PCR array possuem tempos de expressão diferentes (HUANG et al., 2001).

Os dados brutos obtidos da amplificação por RT2 PCR array $(\mathrm{Ct})$ nas etapas de manipulação in vitro dos 6 pacientes $\mathrm{HIV}+$ estudados (apêndice A), foram utilizados para calcular a modulação da expressão (FC) entre as 5 diferentes etapas de diferenciação (iDC, 4 h - DC, 14 h - DC, 24 h - DC e 48 h - DC) e os respectivos monócitos para cada indivíduo.

\subsubsection{Agrupamento hierárquico}

Com o intuito de verificar associação entre o perfil de expressão gênica e as etapas de diferenciação e/ou evidenciar diferenças entre os indivíduos submetidos à imunoterapia construiu-se uma matriz representada por um heat map, considerando-se todos os indivíduos e todas as etapas de diferenciação monócitos-DC avaliadas (Figura 6). Essa abordagem demonstrou que as etapas de diferenciação não apresentaram um padrão de acordo com o perfil de expressão gênica avaliado, no entanto os indivíduos apresentaram, independentemente das etapas do protocolo, diferenças no perfil de expressão, permitindo a segregação dos indivíduos analisados em 2 grupos de perfil de expressão gênica que 
chamamos de A e B (A: P1, P5, P6 e B: P2, P3, P4). Esses grupos mostram perfis de expressão de genes anti-HIV diferentes, sendo possível observar, em geral, uma menor expressão na resposta anti-HIV no grupo A e um maior expressão no grupo B (Figura 6) comparado com os respectivos monócitos. Diante do exposto, as próximas análises do presente estudo considerarão essa divisão dos indivíduos nos grupos A e B.

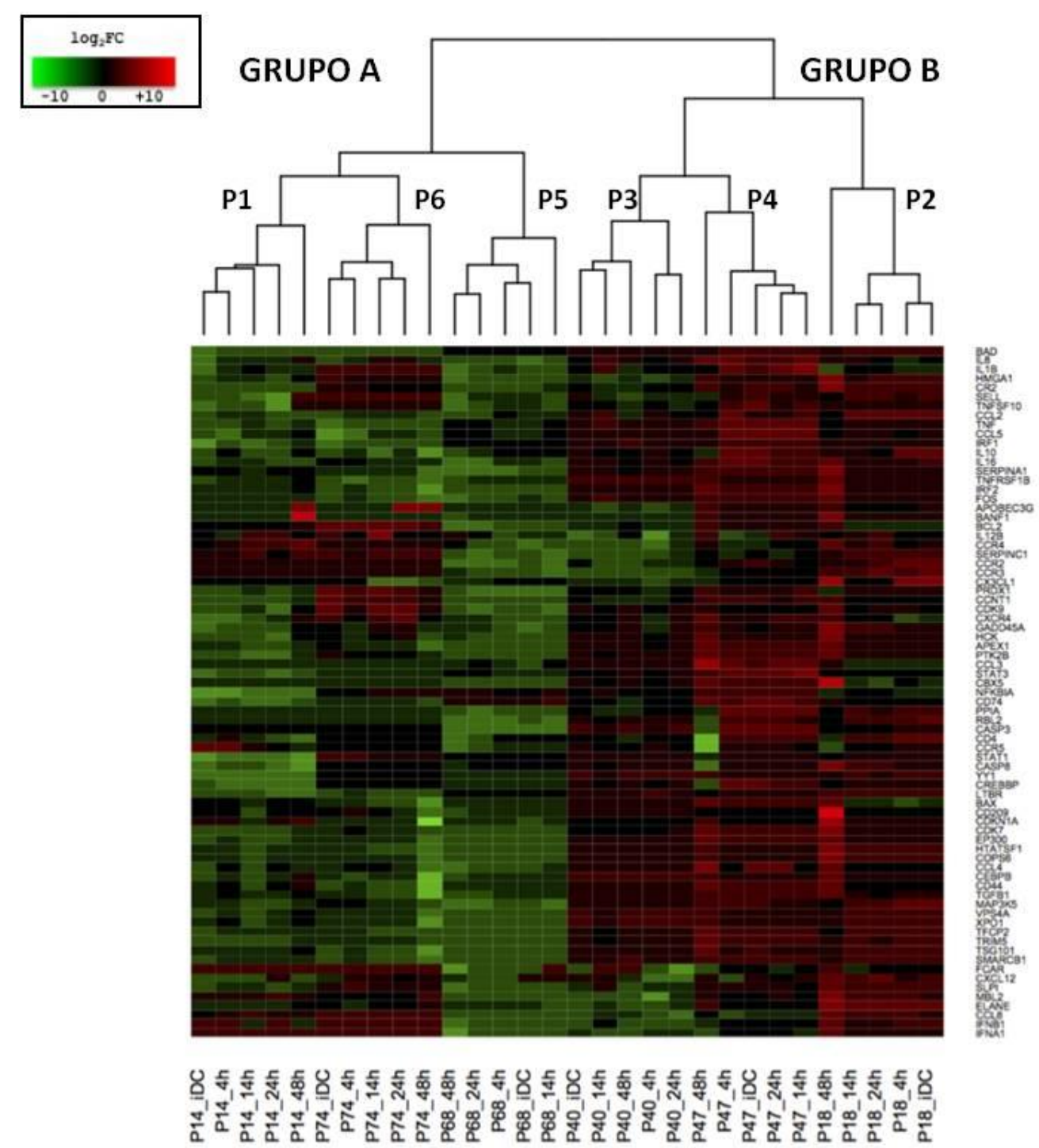

Figura 6 - Heat map do perfil de expressão durante as etapas de diferenciação de monócitos em células dendríticas. Os valores de $\log _{2} \mathrm{FC}$ foram plotados de forma linear com tons de verde, vermelho e preto atribuídos para cada valor, sendo que tons de verde indicam genes subexpressos $\left(\log _{2}\right.$ $\mathrm{FC}<0 ; \mathrm{FC}<1)$, tons de vermelho indicam os superexpressos $\left(\log _{2} \mathrm{FC}>0, \mathrm{FC}>1\right)$ e preto indica uma não modulação ou expressão $\left(\log _{2} \mathrm{FC}=0 ; \mathrm{FC}=1\right)$. $\mathrm{O}$ dendograma superior horizontal mostra $\mathrm{o}$ agrupamento das amostras. 
O fato de encontrarmos grupos tão distintos é intrigante porque os critérios de seleção dos indivíduos a serem incluídos no ensaio clínico são bem específicos (ausência de tratamento, antirretroviral, contagem de CD4 > 350 células/ $\mu 1$, CVP> 3 log) e deveriam dessa forma uniformizar os pacientes.

Quando analisamos a correlação entre o perfil de expressão gênica e os dados clínicos dos pacientes, não encontramos nenhuma correlação significativa nem com CVP nem com os níveis plasmáticos de linfócitos $\mathrm{T}$.

\subsubsection{Modulação da expressão gênica dentro dos grupos A e B}

Para analisar a modulação da expressão gênica dentro dos grupos obtidos com o agrupamento hierárquico, consideramos os valores médios de FC dos 3 pacientes pertencentes ao mesmo grupo, A ou B (Tabela 7).

Tabela 7 - Modulação da expressão gênica nos grupos A e B. São reportados valores de $\log _{2}$ FC resultantes da comparação entre DC e monócitos

\begin{tabular}{|c|c|c|c|c|c|c|c|c|c|c|}
\hline \multicolumn{6}{|c|}{ Grupo A } & \multicolumn{5}{|c|}{ Grupo B } \\
\hline Gene & iDC & $4 \mathrm{~h} \mathrm{DC}$ & 14 h DC & $24 \mathrm{~h} \mathrm{DC}$ & $48 \mathrm{~h}$ DC & iDC & $4 \mathrm{~h} \mathrm{DC}$ & 14 h DC & 24 h DC & $48 \mathrm{~h}$ DC \\
\hline APEXI & $-1,87$ & $-2,41$ & $-1,6$ & $-2,86$ & $-3,62$ & 3,51 & 3,32 & 3,41 & 3,16 & 5,37 \\
\hline АРОВЕС $3 G$ & NA & NA & $-0,17$ & 5,77 & 7,31 & 3,11 & 2,49 & 2,36 & 3,2 & 4,68 \\
\hline$B A D$ & $-12,45$ & $-11,98$ & $-6,03$ & $-11,97$ & $-10,98$ & 4,28 & 4,06 & 4,01 & 4,13 & 2,74 \\
\hline BANF1 & NA & NA & 0,58 & NA & 6,02 & 2,8 & 2,84 & 2,82 & 2,6 & 4,89 \\
\hline$B A X$ & $-3,8$ & $-3,52$ & $-1,88$ & $-3,85$ & $-5,34$ & 1,2 & $-0,24$ & 0,79 & 1,02 & 5,62 \\
\hline BCL2 & 2,39 & 2,86 & 0,48 & 2,76 & 2,56 & 1,56 & 1,42 & 1,25 & 1,56 & 4,24 \\
\hline CASP3 & NA & NA & $-0,48$ & NA & NA & 1,55 & 1,48 & 1,18 & 1,39 & 0,33 \\
\hline CASP8 & $-3,23$ & $-2,17$ & $-1,7$ & $-3,89$ & $-4,63$ & 2,24 & 2,27 & 1,86 & 2,35 & 1,02 \\
\hline$C B X 5$ & NA & NA & $-0,2$ & NA & NA & 1,62 & 1,66 & 1,71 & 1,28 & 5,54 \\
\hline$C C L 2$ & $-8,45$ & $-5,96$ & $-3,97$ & $-9,04$ & $-9,8$ & 0,57 & 2,42 & 1,82 & $-0,57$ & $-4,4$ \\
\hline CCL3 & NA & NA & 2,53 & NA & NA & 3,5 & 4,1 & 4,28 & 4,01 & 4,64 \\
\hline CCL4 & $-4,19$ & $-1,31$ & $-1,33$ & $-2,72$ & $-5,1$ & 2,71 & 1,4 & 1,53 & 2,65 & 4,66 \\
\hline CCL5 & $-6,86$ & $-6,45$ & $-1,25$ & $-3,34$ & $-3,36$ & 2,08 & 0,79 & 2,44 & 2,75 & $-0,27$ \\
\hline CCL8 & $-9,17$ & $-7,11$ & $-7,47$ & $-7,22$ & $-7,34$ & $-7,78$ & $-8,51$ & $-6,15$ & $-7,18$ & $-4,87$ \\
\hline CCNT1 & $-0,13$ & $-0,31$ & $-2,31$ & $-0,57$ & $-0,6$ & 1,98 & 1,73 & 1,44 & 1,83 & 3,66 \\
\hline CCR2 & NA & NA & $-6,28$ & NA & NA & 1,66 & $-0,33$ & $-2,33$ & $-1,02$ & $-2,58$ \\
\hline CCR3 & NA & NA & $-8,55$ & NA & NA & $-0,7$ & $-2,2$ & $-2,57$ & $-1,27$ & $-2,88$ \\
\hline CCR4 & $-4,84$ & $-2,87$ & $-3,93$ & $-1,64$ & 1,43 & $-4,04$ & $-4,65$ & $-3,46$ & -2 & 0,5 \\
\hline CCR5 & 0,62 & 0,65 & $-0,28$ & $-0,93$ & $-2,35$ & 0,52 & 0,58 & $-0,24$ & $-0,03$ & $-2,65$ \\
\hline CD209 & $-1,06$ & $-0,33$ & $-1,31$ & $-1,94$ & $-4,37$ & 0,48 & 0,58 & 0,55 & 0,12 & 5,43 \\
\hline CD4 & $-0,73$ & 0,14 & $-0,77$ & $-2,23$ & $-3,7$ & 2,25 & 2,11 & 1,57 & 1,35 & $-3,14$ \\
\hline CD44 & $-2,66$ & $-2,34$ & $-1,41$ & $-2,35$ & $-4,51$ & 2,19 & 2,19 & 2,33 & 2,21 & 5,35 \\
\hline
\end{tabular}




\begin{tabular}{|c|c|c|c|c|c|c|c|c|c|c|}
\hline \multirow[b]{2}{*}{ Gene } & \multicolumn{5}{|c|}{ Grupo A } & \multicolumn{5}{|c|}{ Grupo B } \\
\hline & iDC & $4 \mathrm{~h} \mathrm{DC}$ & $14 \mathrm{~h} \mathrm{DC}$ & 24 h DC & 48 h DC & iDC & $4 \mathrm{~h} \mathrm{DC}$ & $14 \mathrm{~h} \mathrm{DC}$ & 24 h DC & $48 \mathrm{~h}$ DC \\
\hline$C D 74$ & $-1,05$ & $-0,64$ & $-0,28$ & $-1,23$ & $-1,58$ & 1,81 & 1,75 & 1,77 & 1,72 & 2,15 \\
\hline$C D K 7$ & $-3,87$ & $-3,42$ & $-3,34$ & $-3,82$ & $-4,25$ & 2,49 & 2,34 & 2,15 & 2,59 & 4,98 \\
\hline CDK9 & 0,26 & $-1,01$ & $-1,29$ & $-0,53$ & 0,26 & 1,45 & 0,84 & 1,37 & 1,37 & 3,77 \\
\hline CDKN1A & $-2,54$ & $-1,61$ & $-2,87$ & $-1,7$ & $-4,13$ & $-0,79$ & $-0,61$ & $-0,63$ & $-0,51$ & 3,38 \\
\hline СЕВPB & $-3,74$ & $-3,57$ & $-1,82$ & $-2,93$ & $-4,67$ & 1,15 & 1,18 & 1,34 & 1,03 & 3,74 \\
\hline$C R 2$ & $-4,43$ & $-3,84$ & $-5,52$ & $-5,34$ & $-4,99$ & 0,29 & 0,04 & $-0,36$ & 0,53 & 1,25 \\
\hline CREBBP & $-2,06$ & $-2,28$ & $-1,79$ & $-3,11$ & $-2,95$ & 1,59 & 1,24 & 0,98 & 1,41 & $-0,95$ \\
\hline CX3CL1 & NA & NA & $-2,58$ & $-5,73$ & $-5,12$ & 1,78 & 1,24 & $-2,04$ & $-2,38$ & 1,15 \\
\hline CXCR4 & $-0,52$ & $-1,7$ & $-0,96$ & 1,77 & 1,13 & 1,56 & 0,68 & 2,62 & 3,17 & 6,05 \\
\hline$E L A N E$ & $-6,83$ & $-8,46$ & $-9,09$ & $-7,34$ & $-6,22$ & $-4,11$ & $-4,28$ & $-3,5$ & $-3,85$ & $-1,79$ \\
\hline EP300 & $-4,45$ & $-4,04$ & $-2,99$ & $-4,53$ & $-5,07$ & 2,69 & 2,63 & 2,28 & 2,56 & 4,86 \\
\hline$F C A R$ & NA & NA & NA & NA & NA & $-9,97$ & $-9,3$ & $-10,31$ & $-12,83$ & $-16,89$ \\
\hline$G A D D 45 A$ & $-1,26$ & $-1,16$ & $-0,72$ & 0,49 & 1,11 & 2,82 & 2,75 & 3,6 & 4,53 & 6,21 \\
\hline$H C K$ & $-1,63$ & $-2,9$ & $-1,6$ & $-1,51$ & $-1,54$ & 2,93 & 2,55 & 2,87 & 3,15 & 5,66 \\
\hline FOS & $-5,9$ & $-5,47$ & $-3,26$ & $-6,48$ & $-8,03$ & 1,62 & 1,48 & 1,54 & 0,99 & 2,86 \\
\hline IFNB1 & NA & NA & $-6,98$ & NA & $-9,22$ & $-3,81$ & $-4,55$ & $-3,09$ & $-4,9$ & $-4,59$ \\
\hline IL10 & $-4,74$ & $-3,7$ & $-4,07$ & $-5,86$ & $-6,11$ & 1,37 & 1,62 & $-0,53$ & $-1,49$ & $-2,22$ \\
\hline$I L 12 B$ & $-0,55$ & $-3,5$ & $-1,61$ & 1,58 & NA & $-4,18$ & $-6,23$ & $-0,67$ & 2,07 & 2,02 \\
\hline IL16 & $-4,48$ & $-4,28$ & $-4,71$ & $-6,93$ & $-7,46$ & 1,88 & 1,69 & 0,52 & $-0,18$ & 1,3 \\
\hline$I L 1 B$ & $-8,88$ & $-7,35$ & $-3,61$ & $-7,98$ & $-8,39$ & $-2,61$ & $-2,62$ & 0,86 & $-1,51$ & $-5,94$ \\
\hline$I L 8$ & $-9,43$ & $-7,16$ & $-3,62$ & $-4,96$ & $-5,37$ & $-1,48$ & $-1,24$ & 1,98 & 0,48 & 1,49 \\
\hline$I R F 1$ & $-7,06$ & $-5,43$ & $-2,87$ & $-5,04$ & $-4,11$ & 1,12 & 1,89 & 1,63 & 1,93 & 0,82 \\
\hline$I R F 2$ & $-5,45$ & $-5,03$ & $-3,41$ & $-5,21$ & $-6,09$ & 1,23 & 1,22 & 1,08 & 1,37 & 4,09 \\
\hline$L T B R$ & $-2,57$ & $-2,37$ & $-0,91$ & -3 & $-2,95$ & 1,64 & 1,64 & 1,48 & 1,39 & 0,75 \\
\hline МАРЗК5 & $-2,24$ & $-2,49$ & $-2,77$ & $-3,57$ & $-3,93$ & 2,51 & 2,28 & 1,41 & 1,97 & 1,88 \\
\hline$M B L 2$ & $-6,46$ & $-6,48$ & $-7,6$ & $-5,39$ & $-4,03$ & $-6,91$ & $-7,68$ & $-4,91$ & $-3,56$ & $-2,04$ \\
\hline NFKBIA & $-1,22$ & $-0,84$ & 0,77 & 1,02 & 1,25 & 2,04 & 1,93 & 2,84 & 2,55 & 2,24 \\
\hline PPIA & NA & NA & $-1,04$ & NA & NA & 3,17 & 3,02 & 2,61 & 2,87 & $-0,01$ \\
\hline$P R D X 1$ & 0,16 & 0,06 & $-1,46$ & $-0,08$ & 0,33 & 2,79 & 2,44 & 2,68 & 2,99 & 3,33 \\
\hline PTK2B & $-3,05$ & $-3,67$ & $-3,7$ & $-3,84$ & $-3,23$ & 2,58 & 2,21 & 1,58 & 2,29 & 4,57 \\
\hline$R B L 2$ & NA & NA & $-0,7$ & NA & NA & 2,31 & 2,18 & 1,69 & 2,14 & 0,33 \\
\hline SELL & $-4,63$ & $-5,12$ & $-5,3$ & $-6,59$ & NA & 0,13 & $-2,07$ & $-1,82$ & $-1,73$ & $-4,32$ \\
\hline SERPINAI & $-5,62$ & $-5,71$ & $-4,98$ & $-5,59$ & $-6,92$ & $-0,24$ & $-0,6$ & $-0,43$ & $-0,39$ & 1,25 \\
\hline SERPINC1 & $-0,29$ & $-1,63$ & $-4,1$ & $-1,25$ & 0,05 & $-1,92$ & $-3,04$ & $-2,52$ & $-1,81$ & $-3,39$ \\
\hline SLPI & $-10,42$ & $-9,41$ & $-10,22$ & $-11,24$ & $-10,97$ & $-6,46$ & $-6,82$ & $-6,28$ & $-6,2$ & $-6,02$ \\
\hline$S M A R C B 1$ & $-5,76$ & $-5,26$ & $-3,09$ & $-5,41$ & $-6,35$ & 2,33 & 2,29 & 2,13 & 2,26 & 2,71 \\
\hline STAT1 & $-1,45$ & 0 & $-1,29$ & $-1,1$ & $-1,54$ & 1,52 & 1,69 & 1,37 & 1,49 & 0,06 \\
\hline STAT3 & $-1,17$ & $-1,1$ & $-0,33$ & $-1,23$ & $-0,51$ & 2,6 & 2,5 & 2,45 & 2,66 & 2,04 \\
\hline$T F C P 2$ & $-4,79$ & $-4,44$ & $-3,56$ & $-5,02$ & $-5,61$ & 3,15 & 3,03 & 2,36 & 3,08 & 3,5 \\
\hline$T G F B 1$ & $-3,82$ & $-3,27$ & $-2,03$ & $-5,05$ & $-7,09$ & 1,93 & 2,02 & 1,99 & 1,48 & 3,9 \\
\hline$T N F$ & $-8,59$ & $-7,56$ & $-2,5$ & $-6,44$ & $-6,21$ & 0,42 & 0,3 & 2,09 & 1,19 & $-0,73$ \\
\hline TNFRSF1B & $-7,13$ & $-6,81$ & $-3,24$ & $-5,97$ & $-6,64$ & 0,83 & 0,8 & 0,78 & 0,86 & 2,92 \\
\hline TNFSF10 & $-7,63$ & $-7,8$ & -7 & $-10,51$ & NA & $-0,09$ & $-1,19$ & $-1,73$ & $-2,61$ & $-3,18$ \\
\hline
\end{tabular}




\begin{tabular}{c|ccccc|ccccc} 
& \multicolumn{5}{|c|}{ Grupo A } & \multicolumn{5}{c}{ Grupo B } \\
\hline Gene & iDC & 4 h DC & $\mathbf{1 4}$ h DC & $\mathbf{2 4}$ h DC & $\mathbf{4 8}$ h DC & iDC & $\mathbf{4}$ h DC & $\mathbf{1 4}$ h DC & $\mathbf{2 4}$ h DC & $\mathbf{4 8}$ h DC \\
\hline TRIM5 & $-5,12$ & $-4,75$ & $-3,98$ & $-5,14$ & $-5,57$ & 2,02 & 1,94 & 1,48 & 1,67 & 2,47 \\
TSG101 & $-4,95$ & $-4,58$ & $-3,15$ & $-4,85$ & $-5,87$ & 1,82 & 1,75 & 1,63 & 1,84 & 2,63 \\
VPS4A & $-4,46$ & $-3,83$ & $-2,6$ & $-4,28$ & $-5,14$ & 2,15 & 2,17 & 2,04 & 2,01 & 2,87 \\
XPO1 & $-3,73$ & $-3,08$ & $-2,67$ & $-3,7$ & $-4,91$ & 1,48 & 1,51 & 1,28 & 1,39 & 2,33 \\
YY1 & $-1,95$ & $-2,19$ & $-0,93$ & $-2,31$ & $-2,37$ & 1,75 & 1,72 & 1,53 & 1,63 & 2,05 \\
\hline
\end{tabular}

Abreviações: NA não amplificado

Em seguida, foram comparadas as modulações da expressão gênica para cada gene entre os 2 grupos, A e B (t test) e os genes ordenados de acordo com o $p$-value resultante e com o valor absoluto de FC. Os genes com um $p$-value $<0.05$ e um valor absoluto de FC > 4 $\left(\log _{2} \mathrm{FC}>2\right)$ foram selecionados como diferentemente expressos (tabela 8).

Tabela 8 - Genes diferentemente expressos em células dendríticas no grupo A e B

\begin{tabular}{|c|c|c|c|c|c|c|c|c|c|c|c|}
\hline \multirow[b]{2}{*}{ Genes } & \multicolumn{5}{|c|}{ GRUPO A } & \multirow[b]{2}{*}{ Genes } & \multicolumn{5}{|c|}{ GRUPO B } \\
\hline & iDC & $4 \mathrm{~h}$ & $14 \mathrm{~h}$ & $24 \mathrm{~h}$ & $48 \mathrm{~h}$ & & iDC & $4 \mathrm{~h}$ & $14 \mathrm{~h}$ & $24 \mathrm{~h}$ & $48 \mathrm{~h}$ \\
\hline \multicolumn{12}{|c|}{ RECEPTORES E LIGANTES NATURAIS DO HIV } \\
\hline CCL5 & -6.86 & -6.45 & $-1.25^{*}$ & $-3.34 *$ & $-3.36^{*}$ & CCL2 & NA & $2.42 *$ & 1.82 & NA & -4.40 \\
\hline$C D 4$ & $-0.73 *$ & $0.14 *$ & $-0.77 *$ & -2.23 & -3.70 & CXCR4 & $1.56^{*}$ & NA & $2.62 *$ & $3.17 *$ & 6.05 \\
\hline \multicolumn{12}{|c|}{ RESPOSTA IMUNE INATA } \\
\hline$I L 1 B$ & $-8,88$ & $-7.35^{*}$ & $-3.61 *$ & $-7.98 *$ & $-8.39 *$ & $F C A R$ & $-9,97$ & $-9,3$ & $-10,3$ & $-12,8$ & $16.89 *$ \\
\hline$\overline{I L 10}$ & $-4.74 *$ & $-3.70 *$ & $-4.07 *$ & $-5.86^{*}$ & $-6,11$ & $\underline{I L 1 B}$ & $-2.61 *$ & $-2.62 *$ & NA & $-1.51 *$ & $-5,94$ \\
\hline$\underline{S E L L}$ & $-4.63^{*}$ & $-5.12 *$ & $-5,3$ & $-6.59 *$ & NA & $\overline{I L 12 B}$ & $-4.18 *$ & $-6,23$ & NA & $2.07 *$ & $2.02 *$ \\
\hline TNFSF 10 & $-7,63$ & $-7.80 *$ & $-7.00 *$ & $-10.51 *$ & NA & PRDX1 & 2,79 & $2.44 *$ & 2,68 & 2,99 & 3,33 \\
\hline$T N F$ & $-8,59$ & $-7.56^{*}$ & $-2.50^{*}$ & $-6.44 *$ & $-6.21 *$ & $\underline{S E L L}$ & NA & $-2.07 *$ & $-1.82 *$ & $-1.73 *$ & $-4,32$ \\
\hline \multicolumn{12}{|c|}{ PROTEÍNAS CELULARES INDUZIDAS OU ATIVADAS PELA INFECÇÃO DO HIV } \\
\hline $\boldsymbol{B A D}$ & -12.45 & -11.98 & -6.03 & -11.97 & -10.98 & $\boldsymbol{B A D}$ & 4.28 & $4.06^{3}$ & 4.01 & 4.13 & $2.74 *$ \\
\hline CASP8 & $-3.23 *$ & $-2.17 *$ & -1.70 & -3.89 & $-4.63 *$ & $B A X$ & $1.20 *$ & NA & NA & $1.02 *$ & 5.62 \\
\hline$I R F 1$ & -7.06 & $-5.43^{*}$ & $-2.87 *$ & $-5.04 *$ & $-4.11 *$ & CASP8 & 2.24 & 2.27 & 1.86 & 2.35 & $1.02 *$ \\
\hline & & & & & & COPS6 & 2,19 & 2,15 & 1,96 & 2,04 & 4,41 \\
\hline & & & & & & $G A D D 45 A$ & 2,82 & $2.75^{*}$ & 3,6 & 4,53 & 6,21 \\
\hline \multicolumn{12}{|c|}{ CO-FATORES CELULARES ENVOLVIDOS NA INFECÇÃO PELO HIV } \\
\hline & & & & & & $C B X 5$ & $1.62 *$ & $1.66^{*}$ & $1.71 *$ & $1.28 *$ & 5,54 \\
\hline & & & & & & $C D K 7$ & $2.49 *$ & $2.34 *$ & $2.15^{*}$ & $2.59 *$ & 4,98 \\
\hline & & & & & & $C D K 9$ & 1.45 & NA & 1.37 & 1.37 & 3.77 \\
\hline & & & & & & EP300 & $2.69 *$ & $2.63^{*}$ & 2.28 & $2.53 *$ & 4.86 \\
\hline & & & & & & $H C K$ & 2,93 & 2,55 & 2,87 & 3,15 & 5,66 \\
\hline & & & & & & HTATSF1 & 2.90 & 2.94 & 2.50 & 2.77 & 4.90 \\
\hline & & & & & & $P T K 2 B$ & 2,58 & 2,21 & $1.58^{*}$ & $2.29 *$ & 4,57 \\
\hline & & & & & & $R B L 2$ & 2,31 & 2,18 & 1,69 & 2,14 & NA \\
\hline & & & & & & SMARCBI & 2.33 & 2.29 & 2.13 & 2.26 & 2.71 \\
\hline & & & & & & $T F C P 2$ & 3.15 & $3.03 *$ & $2.36^{*}$ & $3.08 *$ & 3.50 \\
\hline & & & & & & VPS4A & 2.15 & 2.17 & 2.04 & 2.01 & 2.87 \\
\hline
\end{tabular}

$\left(\mathrm{p}<0.05, \mathrm{FC}>4, \log _{2} \mathrm{FC}>2\right) *: \mathrm{p}>0.05, \mathrm{FC}>4, \log _{2} \mathrm{FC}>2$ 
Para a análise entre o grupo A e B foram consideradas as médias dos valores de $\log _{2}$ FC para cada gene em cada grupo. Em seguida, foi calculado o p-value relativo a cada comparação dentro de cada grupo. Dessa forma, em cada grupo, os genes foram ordenados de acordo com o $p$-value e com o valor absoluto de $\log _{2} \mathrm{FC}$ (tabela 8 ). Os genes com um $p$-value $<0.05$ e um valor absoluto de fold change $(\mathrm{FC})>4$ foram selecionados como diferentemente expressos.

No grupo A apenas poucos genes estavam significativamente modulados. Os genes apoptóticos $B A D$ e $C A S P 8$ estavam menos expressos em todas as etapas de diferenciação em relação ao grupo B. De modo similar, genes da resposta imune, como CCL5, IL1B, IL10, IRF1, SELL, TNF e TNFSF10, estavam down-regulados em células dendríticas (iDC, $4 \mathrm{~h}$ DC, 14 h - DC, 24 h - DC e 48 h - DC) quando comparados com monócitos. Em alguns pontos, a modulação gênica não atingiu um $p$-value estatisticamente significante ( $\mathrm{p}>0.05)$, entretanto o valor de FC foi reportado com o objetivo de destacar que a direção da modulação gênica não mudou ao longo das etapas de diferenciação, nesse caso os valores foram representados com asterisco (tabela 8).

Por outro lado, nas células do grupo B foi observada a modulação estatisticamente significante de 32 dos 84 genes em quase todos os tempos considerados. Nesse grupo, 28 desses 32 genes resultaram mais expressos comparados com os monócitos, enquanto que somente 4 genes estavam menos expressos (tabela 8).

É interessante ressaltar que 5 dos 84 genes estavam significantemente modulados em ambos os grupos $I L 1 B$ e $S E L L$ foram mais expressos no grupo A e B, enquanto $B A D, C A S P 8$ e IRF1 estavam modulados de forma oposta, sendo menos expressos no grupo A e mais expressos com grupo B (tabela 8).

As células do grupo B parecem estar mais ativadas em termos de resposta anti- HIV, mostrando uma maior expressão de fatores de restrição quanto de co-fatores da infecção pelo HIV-1, mas sua expressão aumentada não variou de forma significativa ao longo da diferenciação, talvez devido a características intrínsecas desses pacientes e não devido ao protocolo de preparação de células dendríticas.

Em seguida analisamos a expressão relativa de alguns genes ao longo das etapas de diferenciação monócitos-DC. 


\subsubsection{Modulação de genes relacionados com a morte celular e avaliação da viabilidade celular}

Quando consideramos a expressão relativa de genes modulados nos 2 grupos ao longo das etapas de diferenciação monócitos-DC, observamos que $B A D$ e CASP8 estão sempre menos expressos nas DC quando comparadas com monócitos no grupo A (Figura 7A) e mais expressos no grupo B independentemente da etapa de diferenciação analisada (Figura 7B). Porém enquanto BAD aumenta a sua expressão após a estimulação com o vírus (14 h - DC) nas células do grupo A, a expressão desse gene diminui nas DC do grupo B (48 h - DC).
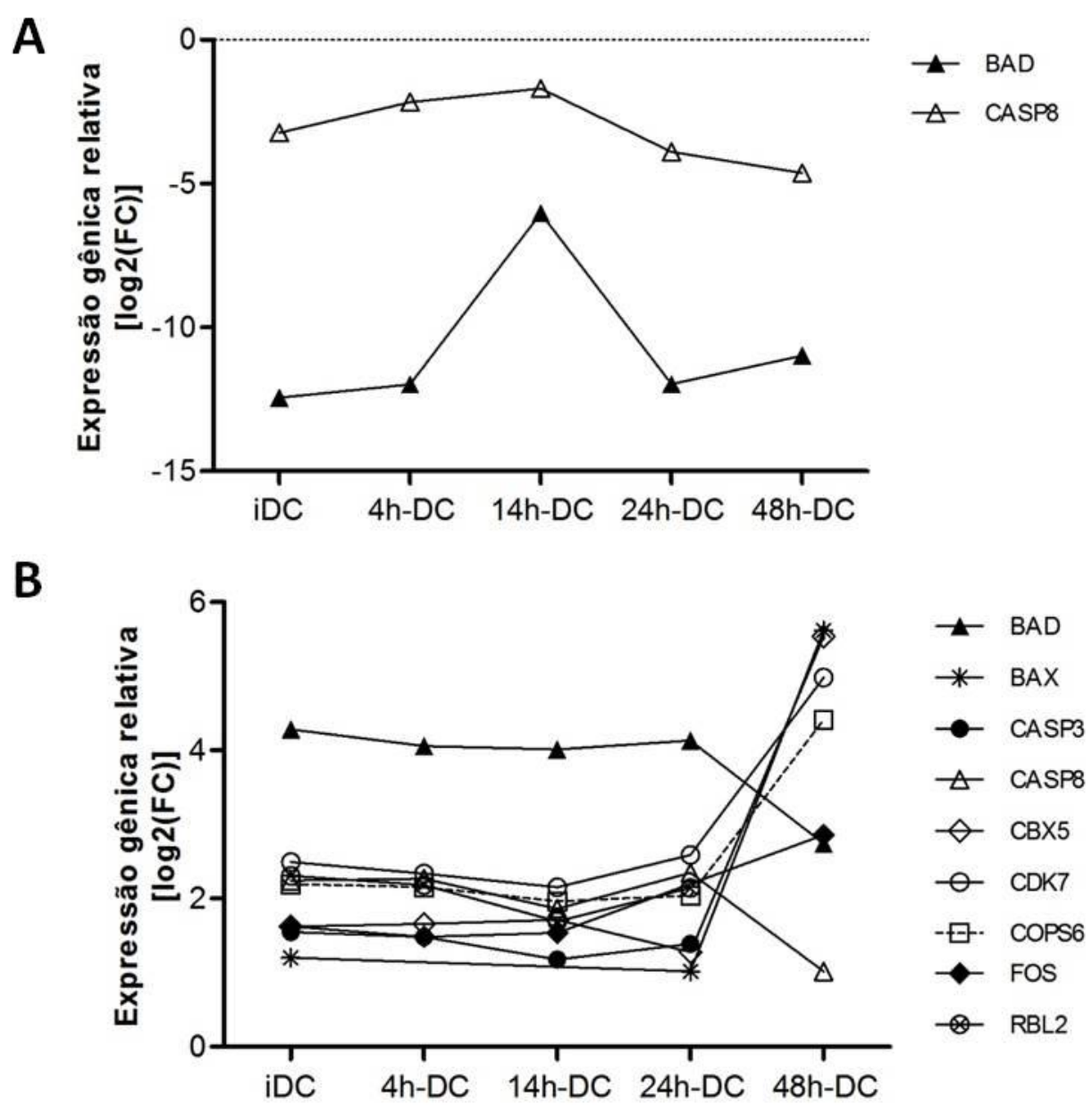

Figura 7 - Expressão relativa de genes diferentemente modulados nas células de indivíduos dos grupos A e B ao longo das etapas de diferenciação. São mostrados no gráfico a expressão gênica de todas a etapas de diferenciação de monócitos a células dendríticas. São reportados valores de $\log _{2} \mathrm{FC}$ resultantes da comparação de células dendríticas contra os monócitos. 
Esse achado não foi corroborado pelo ensaio de viabilidade celular. As 48h - DC de todos os pacientes parecem ser similarmente viáveis (grupo A: $80 \pm 7 \%$ de células negativas para iodeto de propídio; grupo B: $75 \pm 4 \%$; $\mathrm{p}=0.338$ ), entretanto não se pode excluir que a morte celular possa acontecer após 48 horas.

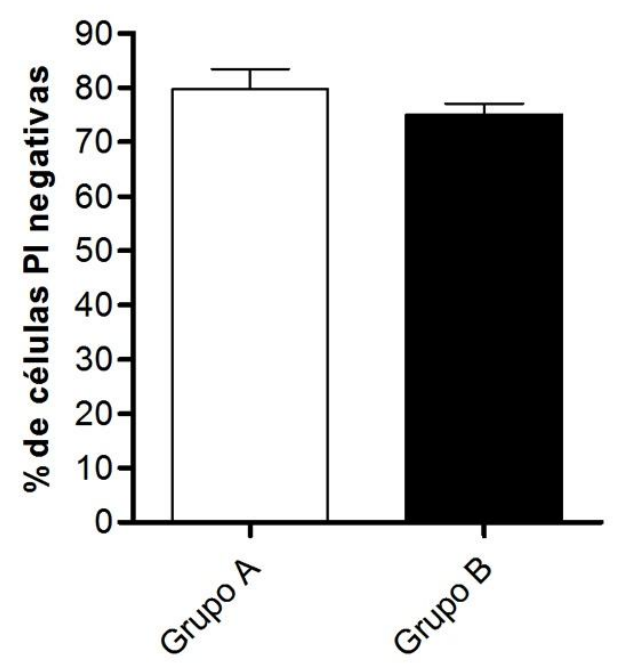

Figura 8 - Ensaio de viabilidade celular das 48 h - DC do grupo A e B. São mostrados no gráfico no grupo A e B a porcentagem de células positivas para laranja de tiazol e negativas para PI (iodeto de propídio). A análise estatística foi feita no software GraphPad Prism®, mediante $t$ test.

\subsubsection{Modulação de genes relacionados com a resposta imune contra o HIV-1}

Quando olhamos para os genes de resposta imune anti-HIV (Figura 9A), é possível observar que a expressão de CCL5, IL1B, IL10, IRF1, SELL, TNF e TNFSF10 estava significativamente reprimida em células dendríticas do grupo A quando comparadas com monócitos. Entretanto os genes CCL5, IL1B, IRF1 e TNF estavam positivamente modulados em 14 h - DC em relação a outros pontos, talvez devido ao efeito sinérgico do pulso viral e adição de citocinas usadas para a cultura celular.

No grupo B, as células dendríticas modularam significativamente os genes $F C A R$, IL1B, IL12B, IRF1, IRF2, SELL e STAT1 (Figura 9B). Além disso, a expressão dos genes $I L 12 B$ e IRF2 aumentou entre 4 e 24 horas, respectivamente, mantendo-se até o fim do protocolo. 


\section{A}

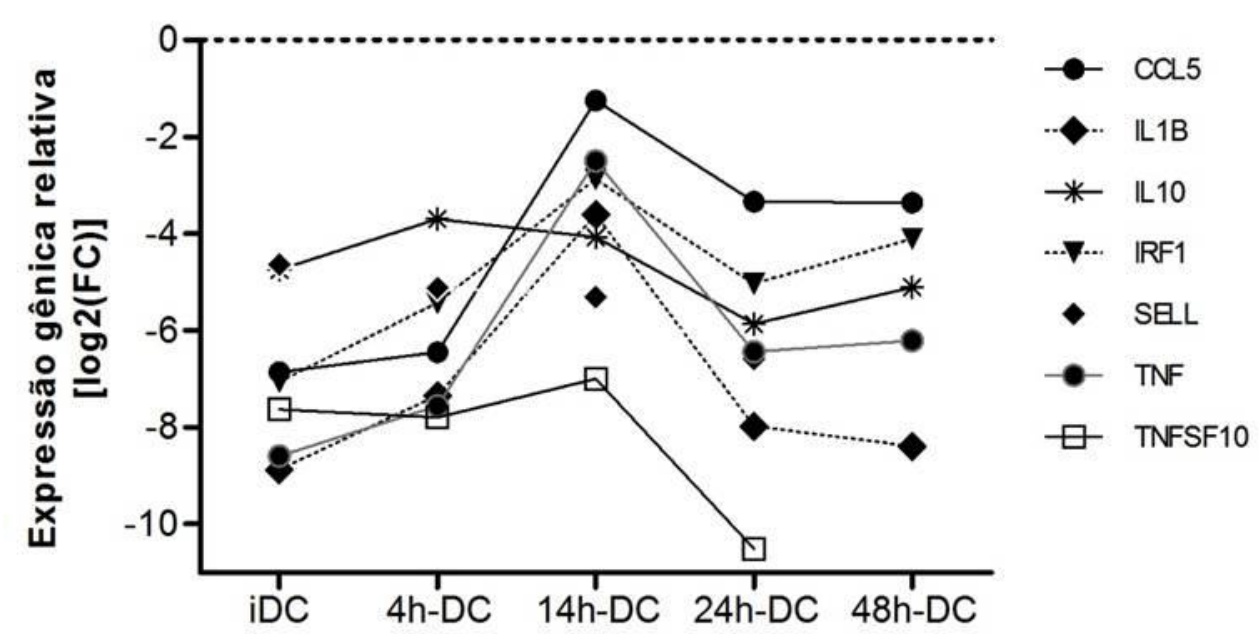

B

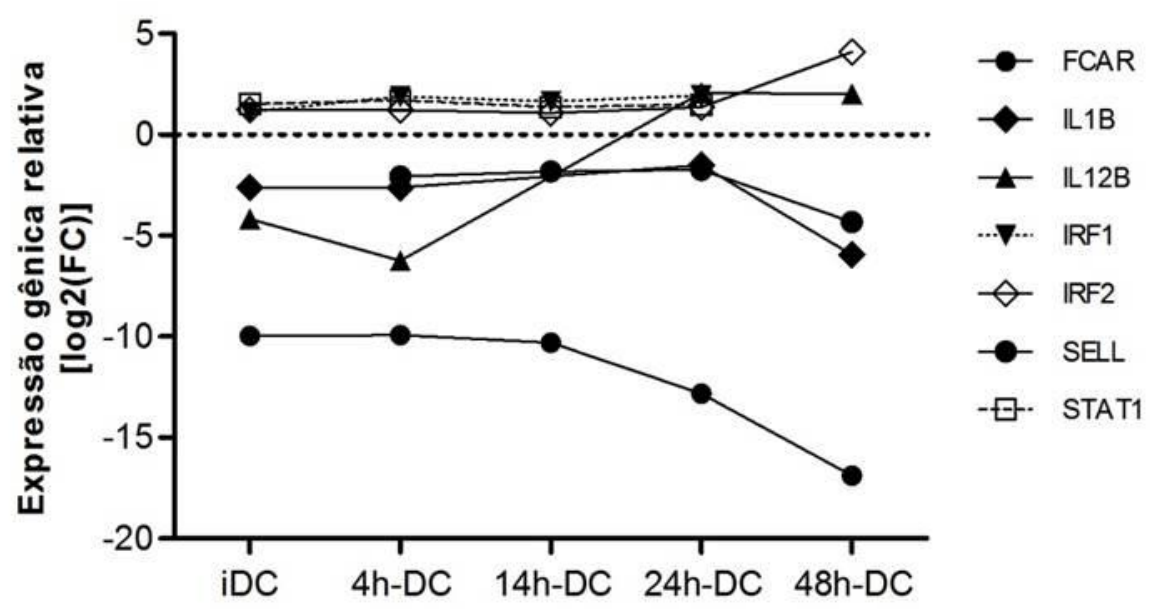

Figura 9 - Expressão relativa de genes relacionados à resposta imune contra o HIV-1 durante as etapas de diferenciação monócitos-DC dos indivíduos HIV+ do grupos A e B. São reportados valores de $\log _{2} \mathrm{FC}$ resultantes da comparação de DC e monócitos.

\subsubsection{Modulação da expressão dos genes do inflamassoma}

Considerando o dado referente ao gene da interleucina 13 , IL1B, (Tabela 7 e Figura 10), a importância da ativação do inflamassoma e da secreção de IL-1ß para a ativação das DC, e os resultados previamente reportados pelo nosso grupo sobre a expressão constitutiva dos genes do inflamassoma em DC de pacientes HIV+ (PONTILLO; SILVA; et al., 2012), foi avaliada a expressão dos genes do inflamassoma NLRP3, CASP1 e IL18 nas etapas de diferenciação de monócitos a DC com um ensaio de sonda específica.

Nenhuma diferença significativa foi observada na modulação de NLRP3 ou CASP1 em células dendríticas quando comparados com monócitos nos dois grupos (Figura 10), de acordo com dados previamente publicados (PONTILLO; SILVA; et al., 2012). Entretanto o 
gene da IL18 estava mais expresso nas DC do grupo A, a 14 h e 48 h (FC=5.19 e 3.85, respectivamente), mas não nas células do grupo $\mathrm{B}(\mathrm{FC}=-1.23$ e 1.34 respectivamente). A diferença entre a expressão de IL18 em 48 h - DC dos grupos A e do B resultou numa diferença estatística significativa $(\mathrm{p}<0.05)$.

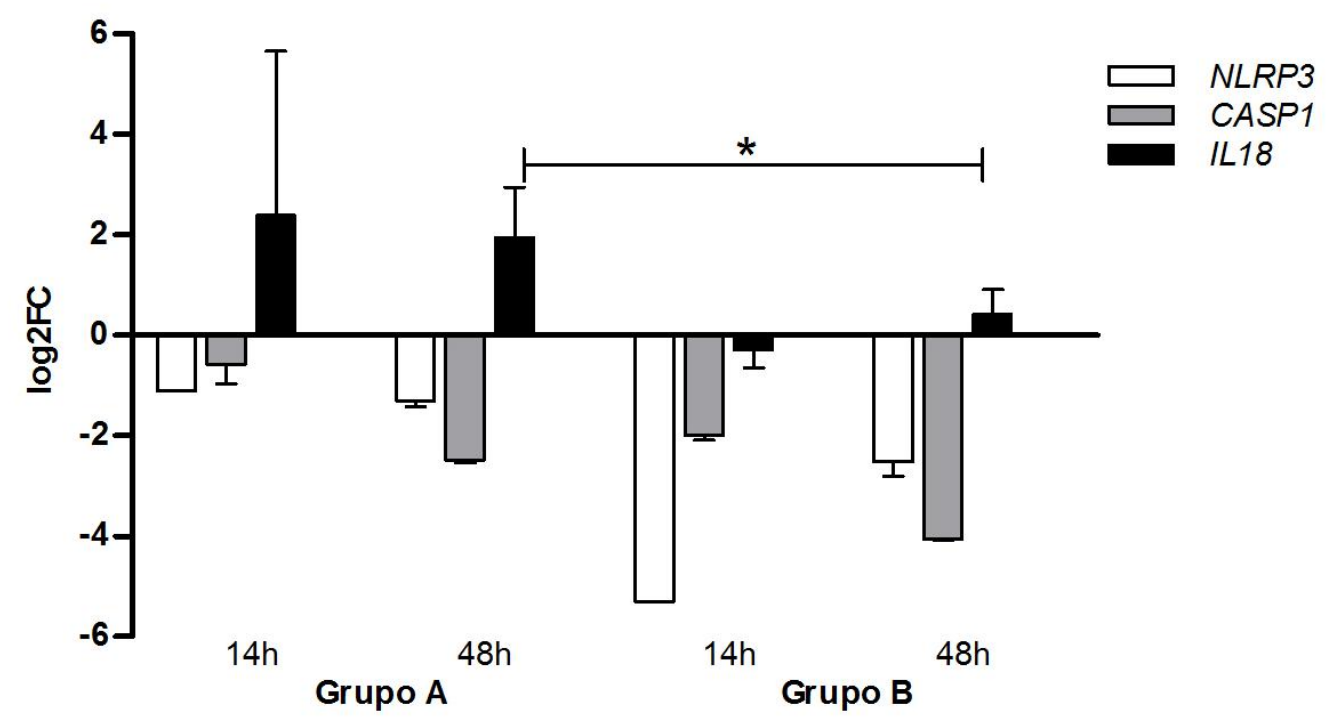

Figura 10 - Expressão relativa de genes do inflamassoma nas 14 h - DC e 48 h - DC. São reportados valores de $\log _{2} \mathrm{FC}$ resultantes da comparação de células dendríticas contra os monócitos nas células dos indivíduos HIV+ do grupo A e B. Os dados foram analisados com Two-Way Anova, seguido do pós-teste de Bonferroni para comparações selecionadas. 


\subsubsection{Avaliação do fenótipo de maturação/ativação em monócitos e células dendríticas}

A caracterização fenotípica de DC imaturas e DC maduras foi realizada através da análise de expressão das seguintes moléculas de superfície celular: CD11c (marcador de células dendríticas mielóides); HLA-DR (antígeno leucocitário humano de classe II); CD80 e CD86 (moléculas co-estimuladoras B7-1 e B7-2, respectivamente); CD83 e CD40 (marcadores de maturação).

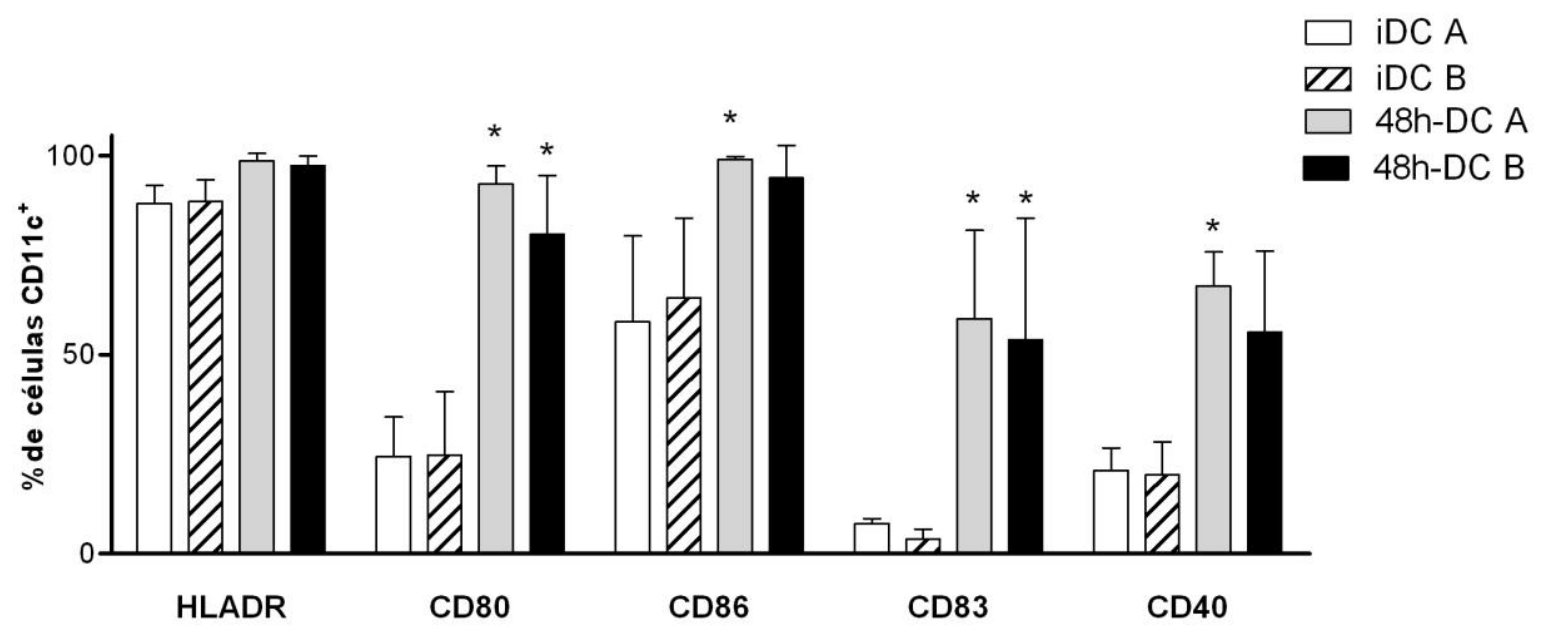

Figura 11 - Perfil fenotípico das células dendríticas imaturas e maduras. Os resultados representam a média de valores de cada grupo $(n=3) \pm$ desvio padrão. As $D C$ foram analisadas de acordo com as características básicas de tamanho e granulosidade e marcadores específicos (CD11c, HLADR, CD80, CD86, CD83, CD40). O CD14 foi usado como controle negativo de diferenciação de monócitos em DC. As barras brancas referem-se às células dendríticas imaturas do grupo A e as barras cinza às células dendríticas maduras do grupo A. As barras com listras representam as células dendríticas imaturas do grupo B e as barras pretas representam as células dendríticas maduras. A análise estatística foi feita no software GraphPad Prism®, mediante o teste two-way ANOVA.

Para os marcadores de superfície CD11c, HLA-DR, CD40, CD80, CD83 e CD86 (Figura 11) não foi observada nenhuma diferença significativa na expressão desses marcadores entre o grupo A e B, entretanto quando a célula dendrítica madura foi comparada com a célula dendrítica imatura, ambos os grupos aumentaram a expressão de CD80 e CD83 de forma estatisticamente significativa, mas somente a célula dendrítica do grupo A aumentou a expressão de CD40 e CD86 ( $<<0.05)$, enfatizando mais uma vez o estado de ativação diferente das células dendríticas imaturas do grupo B. 
4.1.7 Avaliação funcional de células dendríticas: capacidade de induzir produção de IFN- $\gamma$ em ensaios de co-cultivo com linfócitos autólogos

Com o intuito de verificar uma eventual diferença na capacidade das DC em ativar uma resposta específica nos linfócitos dos grupos A e B, foi realizado um ensaio de co-cultivo entre as 48 h - DC e linfócitos autólogos. Para avaliar a ativação linfocitária foi vista a produção de IFN- $\gamma$ através de marcação intracelular e citometria de fluxo. A marcação intracelular de IFN- $\gamma$ em células T autólogas (CD3+ IFN- $\gamma+$ ) após o co-cultivo com DC revelou que ambos os grupos de DC, A e B, induziram a produção de IFN- $\gamma$ de uma forma similar (grupo A: $1.030 \pm 0.461$; grupo B: $1.080 \pm 1.644$; p>0.05) (figura 12).

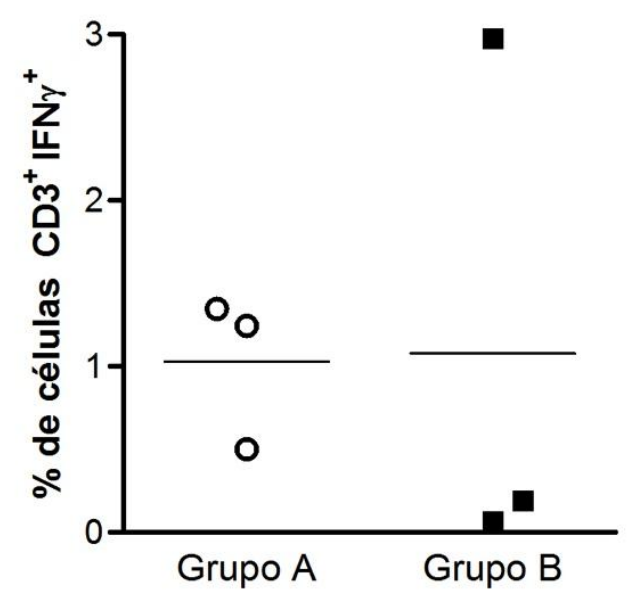

Figura 12 -Linfócitos $T$ produtores de IFN- $\gamma$ após ensaio de co-cultivo DC-linfócitos. São reportadas as porcentagens de linfócitos marcados intracelularmente por IFN- $\gamma(\mathrm{CD} 3+$ IFN- $\gamma+)$. A seleção de linfócitos positivos foi feita por comparação com amostras não-estimuladas, ou seja, cultivadas sem a presença de DC pulsadas. A análise estatística foi feita no software GraphPad Prism ${ }^{\circledR}$, mediante o t test.

\subsection{Discussão: etapas de diferenciação celular de monócitos em células dendríticas}

Tem sido demonstrado que o perfil de expressão de DC pode ser usado com um preditor de funcionalidade e um guia de referência para ensaios clínicos baseados em células dendríticas em terapias para câncer (LIU et al., 2012). Como uma proposta similar, nós investigamos um conjunto de genes envolvidos na resposta anti-HIV em monócitos e células dendríticas usadas no ensaio de fase I/II (FMUSP). A análise da modulação da expressão gênica revelou um perfil diferente de expressão gênica em monócitos e dendríticas ao longo do protocolo de diferenciação in vitro entre os indivíduos estudados (P1-P6). A análise de agrupamento hierárquico separou as células dos pacientes em 2 grupos distintos, que 
indicamos como A e B. A segregação obtida não separou os indivíduos na base dos dados clínicos, como níveis plasmáticos de linfócitos T CD4+ e CD8+ ou carga viral plasmática (tabela 4) ou genéticos disponíveis, sugerindo a necessidade de se investigar os marcadores de caracterização para DC no contexto de uma imunoterapia.

As DC do grupo B aparentemente estão mais ativadas em termos de resposta ao HIV, mostrando uma maior expressão tanto de fatores de restrição quanto de cofatores do HIV-1 (Tabela 8), mas esse aumento de expressão não varia significativamente ao longo da diferenciação, possivelmente devido a características intrínsecas desses pacientes e não em consequência do protocolo de diferenciação de DC.

Além disso, essas células pareciam estar mais propensas à morte celular programada do que o grupo $\mathrm{A}$, já que vários genes pró-apoptóticos $(B A D, B A X, C A S P 8)$ foram significativamente mais expressos no grupo B. De forma contrária, BAD e CASP8 estavam menos expressos em células dendríticas do grupo A. Alguns pesquisadores mostraram que monócitos de indivíduos HIV+ são caracterizados por uma assinatura anti-apoptótica (GIRI et al., 2009), no entanto nenhum dado foi publicado em relação a DC derivadas de monócitos. Podemos hipotetizar que o protocolo de diferenciação de DC a partir de monócitos pode atuar de diferentes maneiras, de acordo com o perfil de expressão original de monócitos, sugerindo que o estado de ativação de monócitos poderia ser levado em conta como um preditor prévio de características de DC antes da maturação dessas células, que atualmente representa um dos principais dados de controle de qualidade da aplicação de DC em pacientes.

A expressão alta de IRF1 foi previamente descrita com um fator que contribui para suscetibilidade a infecção pelo HIV-1 (GIRI et al., 2009). Nossos achados evidenciam uma diferente modulação de expressão nesse fator de transcrição nos dois grupos de células dendríticas, (Figura 9), enfatizando uma vez mais que o perfil genético também pode nos informar sobre a funcionalidade da DC.

O papel emergente da IL-18 na patogênese do HIV tem sido recentemente descrito, sugerindo que a IL-18 poderia ser protetora contra a replicação do HIV (PAULS et al., 2013). A IL-18 desempenha um importante papel na biologia das DC, sendo necessária na indução de células T efetoras (WONG et al., 2013) e células T de memória (KUPZ et al., 2012). Além disso, tem sido observado em DC que o níveis aumentados de IL-18 correlaciona inversamente com IL10 (RODRIGUEZ-GALAN et al., 2009), como foi visto também nos nosso experimentos (Tabela 8).

Todos esses achados apontam que os critérios utilizados atualmente para a seleção dos indivíduos HIV+ para imunoterapia (principalmente CVP e contagem de CD4+ e CD8+) não 
garantem uma ativação genômica adequada das células dendríticas derivadas de monócitos. Entretanto em nossos experimentos, possivelmente devido ao número limitado de indivíduos estudados, as diferenças observadas na expressão gênica não levaram a diferenças significativas em marcadores comumente utilizados para verificar a funcionalidade dessas células, como moléculas de ativação e maturação, ou a habilidade in vitro de induzir a produção de IFN $\gamma$ (Figura 12).

Próximo a finalização dessa primeira parte do projeto, tivemos os resultados de acompanhamento clínico dos pacientes, o quais apontaram que desses 6 indivíduos estudados nenhum respondeu de modo satisfatório à imunoterapia $(\Delta \mathrm{CVP}<1 \log )$. Desse modo, não foi possível correlacionar a diferença no perfil de expressão gênico das células dendríticas com a resposta ao tratamento. 


\section{RESULTADOS E DISCUSSÃO- PARTE II}

Ao final do ensaio clínico, após 6 meses de seguimento apenas um indivíduo HIV+, o $\mathrm{P} 7$, apresentou uma boa resposta $(\triangle \mathrm{CVP}<1 \mathrm{log})$, entre os 11 submetidos à imunoterapia. Os demais vacinados foram classificados como maus respondedores ("weak or transient" responders) $(\triangle \mathrm{CVP}>1 \mathrm{log})$.

A modulação da expressão gênica nos leucócitos circulantes foi avaliada em 6 pacientes (P6-P11). A variação de CVP para os 6 pacientes durante a imunoterapia e o seguimento vacinal está reportada na figura 13.

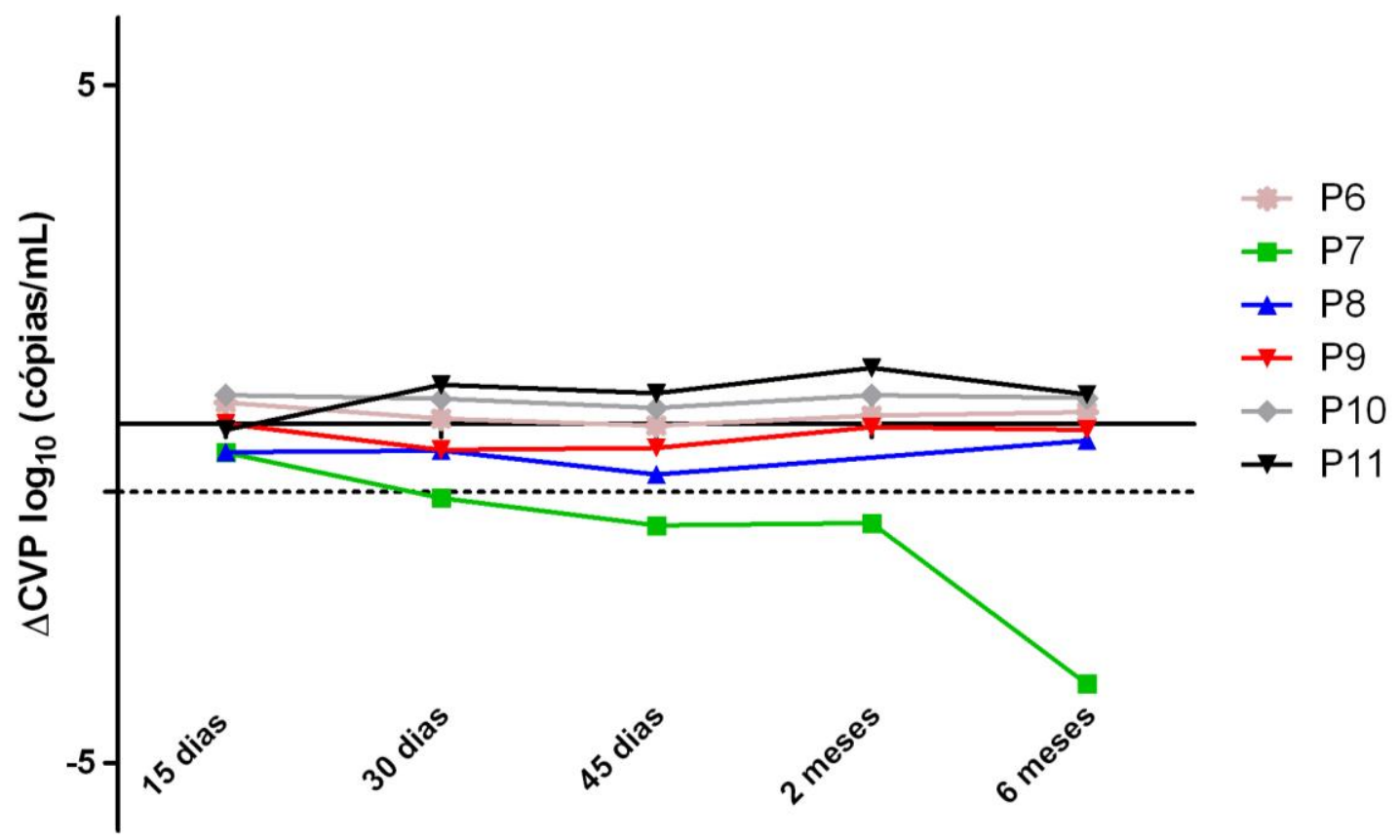

Figura 13 - Dados da variação de carga viral plasmática após a imunoterapia. Nesse gráfico são mostrados os valores de $\triangle \mathrm{CVP}\left(\log _{10}(\mathrm{CVP})\right)$ após a intervenção terapêutica nos pacientes P6-P11 nos tempos t1, t2, t3 $\left(15,30\right.$ e 45 dias após a $1^{\mathrm{a}}$ dose de imunoterapia, respectivamente) e também 2 e 6 meses após a imunoterapia. A linha tracejada indica variação de CVP de 1 log, valor de $\triangle$ CVP considerado como significativo.

\subsection{Análise da expressão gênica em PBMC de indivíduos submetidos à imunoterapia}

A modulação da expressão gênica após a imunoterapia foi avaliada nos PBMC de 6 pacientes (P6-P11) comparando as coletas após o tratamento (t1, t2, t3) com a coleta antes do tratamento (t0). Os dados de FC são reportados no final do trabalho (APÊNDICE B).

Como já descrito em Materiais e Métodos, lembramos que:

- t1: 15 dias após t 0 - 15 dias após dose 1 
- t2: 30 dias após t0 - 15 dias após dose 2

- t3: 45 dias após t0 - 15 dias após dose 3

Vale ressaltar que um intervalo de 15 dias após a administração das doses da vacina é considerado "grande" para poder encontrar modulações agudas da expressão gênica induzida pela imunoterapia (HAGAN et al., 2015; NAKAYA; PULENDRAN, 2015), no entanto o desenho do estudo clínico não permitiu incluir para os pacientes visitas extras e mais próximas à administração de cada dose. Considerando isso, a estratégia de análise dos dados foi alterada em comparação a análise feita na parte I como será descrito a seguir.

\subsection{Análise por heat map e agrupamento hierárquico}

Com o intuito de verificar a associação entre o perfil de expressão gênica e a resposta à imunoterapia, construiu-se uma matriz representada por heat map considerando-se os valores de $\log _{2}$ FC e os tempos de coletas dos 6 pacientes (todos, ou cada tempo t1, t2, t3) (APÊNDICE C). Essa abordagem demonstrou agrupamentos "aleatórios" tanto para tempo quanto para os indivíduos, não permitindo uma segregação evidente dos pacientes.

Diante disso, considerando que as amostras foram coletadas 15 dias após a administração de cada dose da imunoterapia (intervalo de tempo grande para poder evidenciar modulações gênicas induzidas pela imunoterapia) e baseando-se na literatura (HAGAN et al., 2015), hipotetizamos que os genes muito modulados em nossas amostras poderiam representar alterações na expressão gênica decorrentes de eventos agudos e não estar relacionados com o tratamento em si como, por exemplo, efeitos remanescentes de infecções, pequenos traumas ou mal estar. 


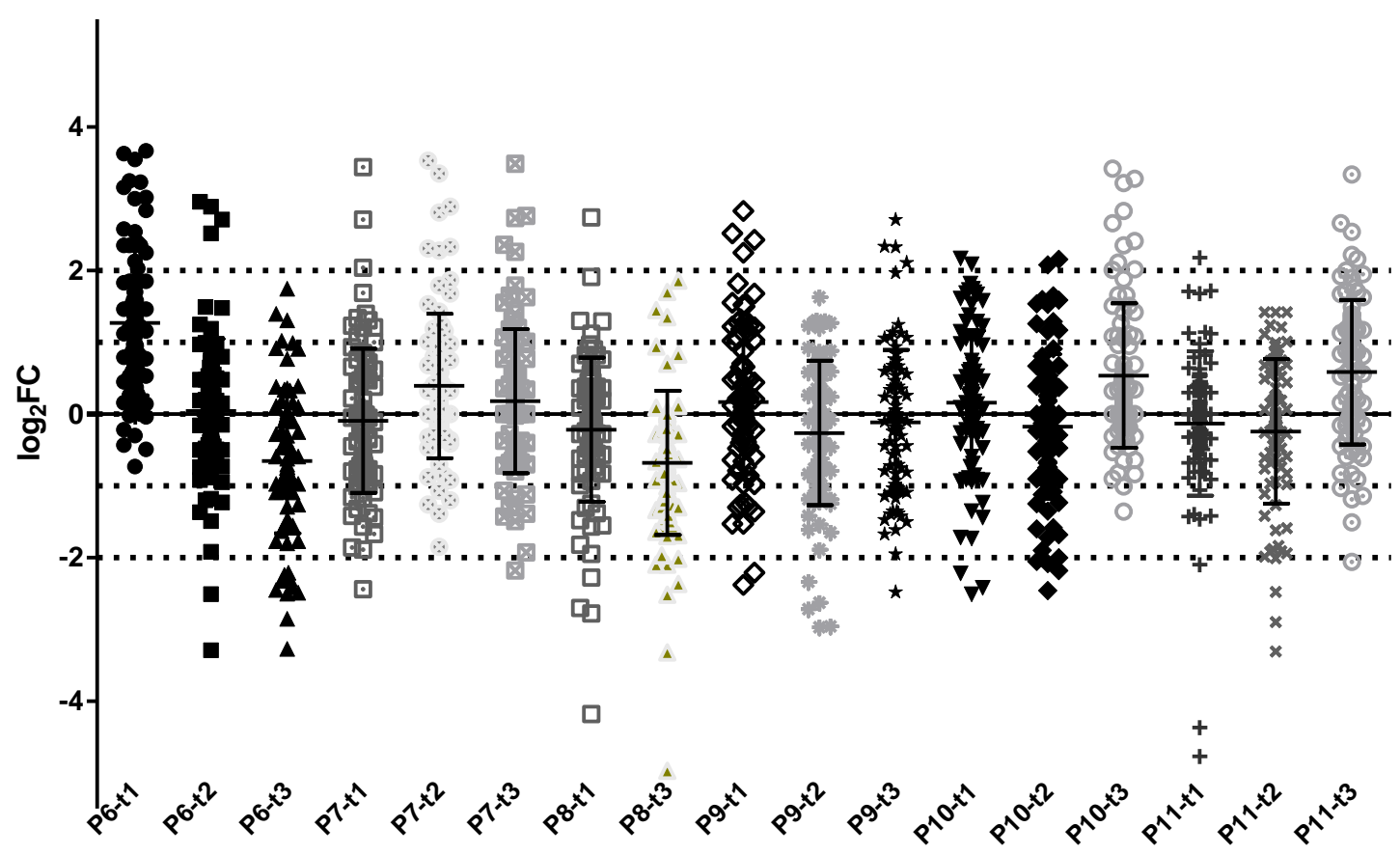

Figura 14 - Expressão relativa dos 86 genes analisados nos PBMC após a imunoterapia. São reportados valores de $\log _{2} \mathrm{FC}$ resultantes da comparação dos PBMC após a imunoterapia (t1, t2, t3) contra os PBMC antes da terapia (t0) para cada indivíduo HIV+ estudado (P6-P11). A linha tracejada indica o intervalo $-2<\log _{2} \mathrm{FC}<2$ (equivalente a $-4<\mathrm{FC}<4$ ).

Assim, decidimos construir uma matriz para cada coleta do acompanhamento vacinal $(\mathrm{t} 1, \mathrm{t} 2, \mathrm{t} 3)$ apenas utilizando os genes com $-4<\mathrm{FC}<4$, os quais, de acordo com a nossa hipótese, seriam os genes com uma modulação mais relacionada aos efeitos exclusivos da imunoterapia. Essa abordagem permitiu a segregação do perfil de expressão do único bom respondedor, o P7, e dos maus respondedores em grupos diferentes em quase todos os tempos analisados. As representações por heat map dessas matrizes são reportadas nas figuras 15, 16 e 17.

Diante do exposto, as próximas análises do presente estudo considerarão somente os genes modulados dentro desse intervalo de FC. 

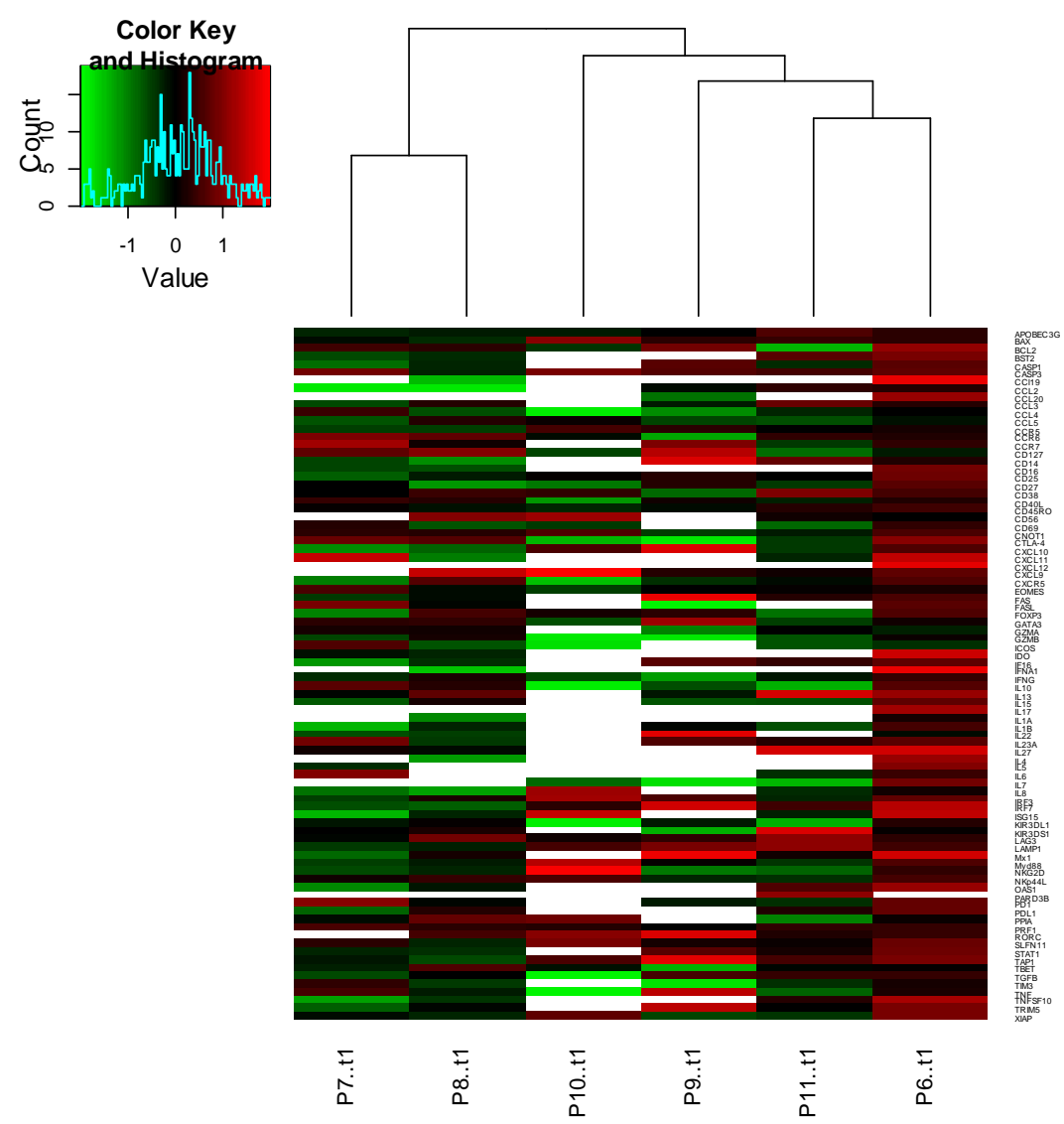

Figura 15 - Heat map e agrupamento hierárquico PBMC após a primeira dose da imunoterapia (t1) São reportados valores de $\log _{2} \mathrm{FC}$ resultantes da comparação dos PBMC após a imunoterapia (t1) contra os PBMC antes da terapia (t0) para cada indivíduo HIV+ estudado (P6-P11). Os espaços em branco referem-se aos genes excluídos da análise. 


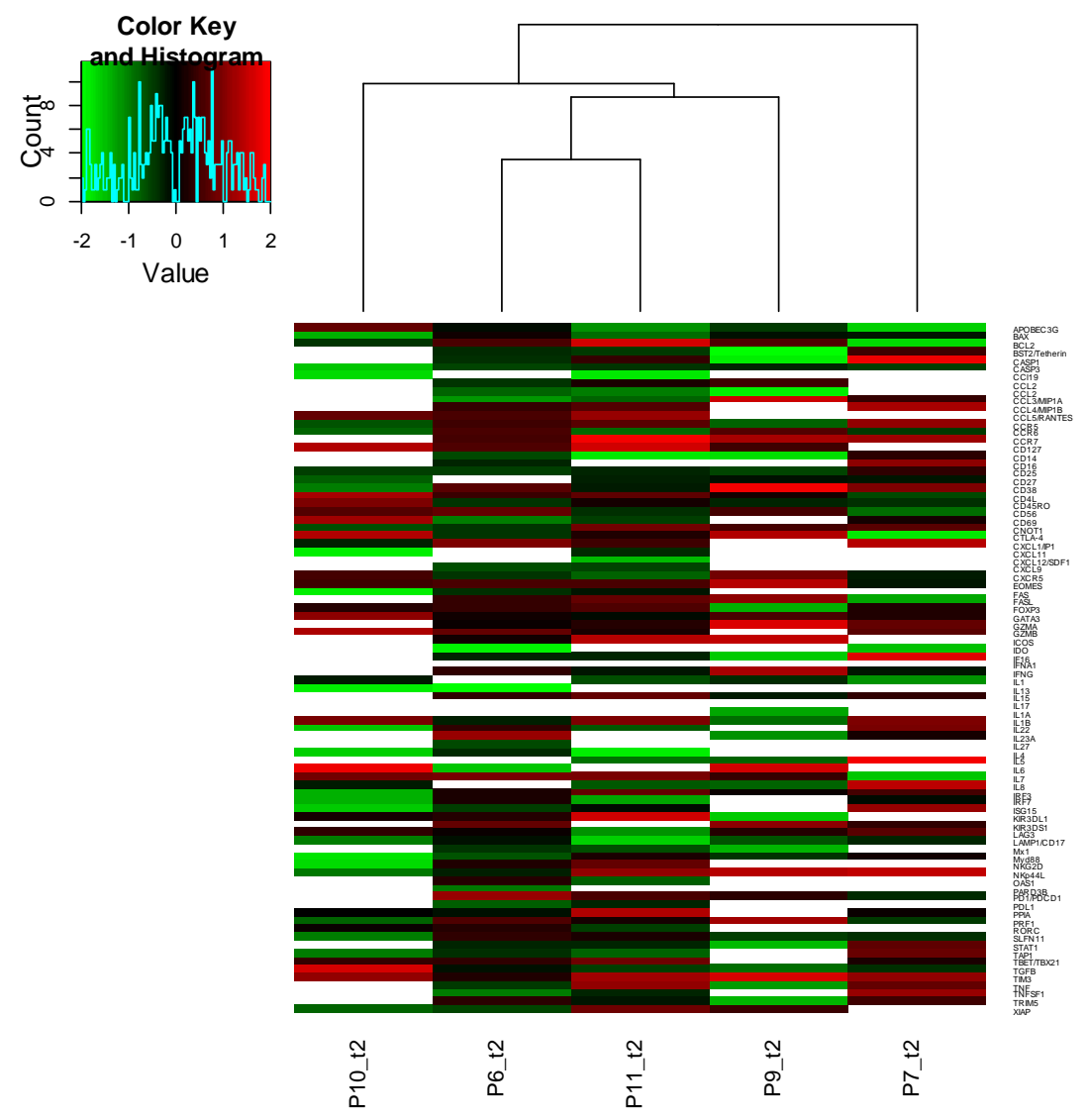

Figura 16 - Heat map e agrupamento hierárquico PBMC após a segunda dose da imunoterapia (t2) São reportados valores de $\log _{2} \mathrm{FC}$ resultantes da comparação dos PBMC após a imunoterapia (t2) contra os PBMC antes da terapia (t0) para cada indivíduo HIV+ estudado (P6-P11). Os espaços em branco referem-se aos genes excluídos da análise. 


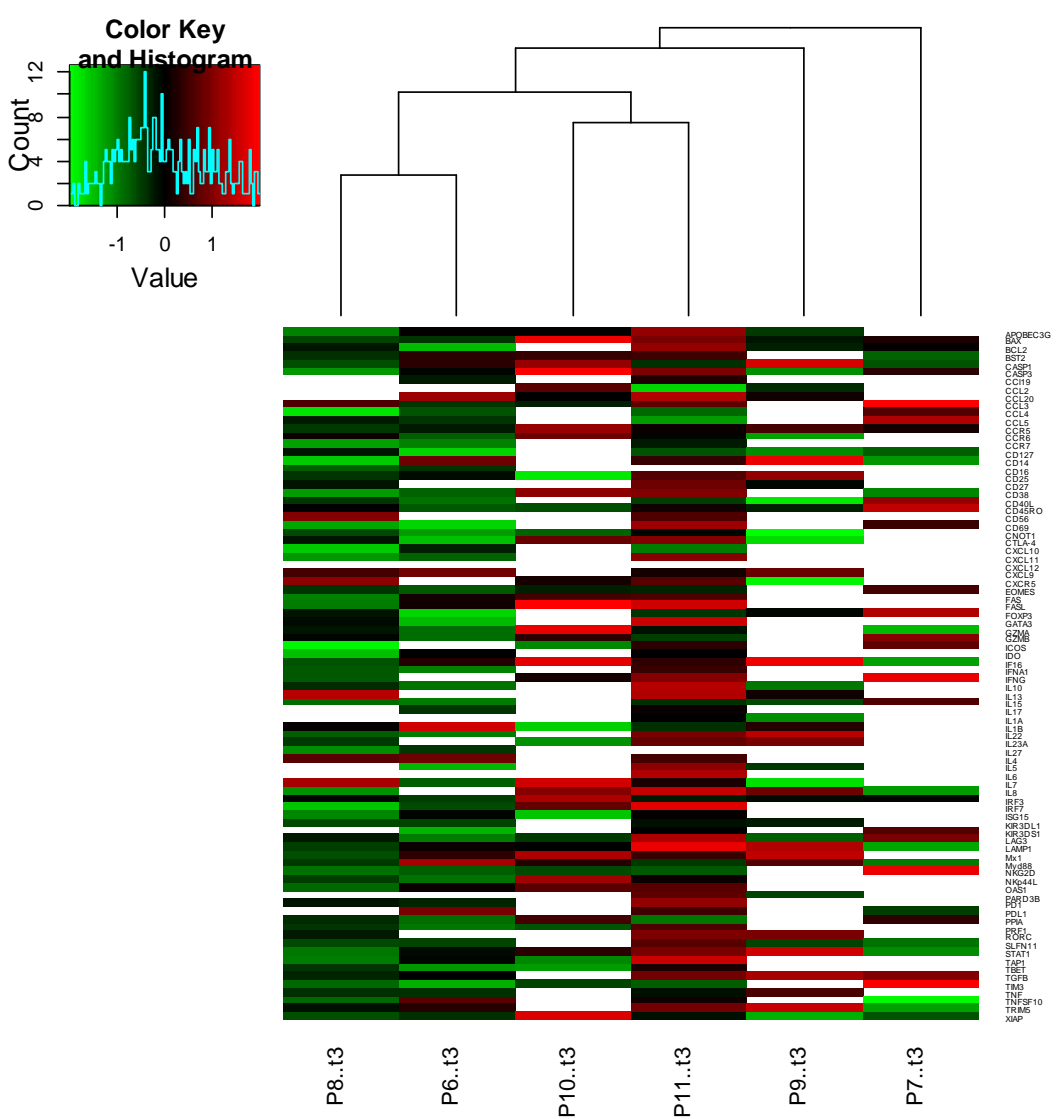

Figura 17 - Heat map e agrupamento hierárquico PBMC após a terceira dose da imunoterapia (t3) São reportados valores de $\log _{2}$ FC resultantes da comparação dos PBMC após a imunoterapia (t3) contra os PBMC antes da terapia (t0) para cada indivíduo HIV+ estudado (P6-P11). Os espaços em branco referem-se aos genes excluídos da análise.

\subsection{Genes modulados em resposta à imunoterapia e análise da função biológica}

Dentro dos genes modulados no intervalo $-4<\mathrm{FC}<4$, avaliamos quais genes apresentaram uma modulação diferente no indivíduo caracterizado por ser um bom respondedor, P7, em relação aos maus respondedores para cada tempo estudado.

Ao analisar os genes modulados após 15 dias da primeira dose de imunoterapia (t1), vimos que no P7 praticamente todos os genes com exceção de 2 (CD56 e IL7) apresentaram $4<\mathrm{FC}<4$ (Figura 15 ). Dentro desses destacam-se os genes CCL4 (FC=1,38), ICOS (FC=1,55), LAG3 (FC=0,97) MX1 (FC=0,57) e PDL1 (FC=0,59) (Tabela 8) que estão modulados de modo oposto no P7 comparado com os maus respondedores. Do outro lado resultou que os genes $R O R C$ (média de $\mathrm{FC}=2,32$ ) e CXCL9 (média de $\mathrm{FC}=2,12$ ) estavam modulados apenas nos maus respondedores (Tabela 9). 


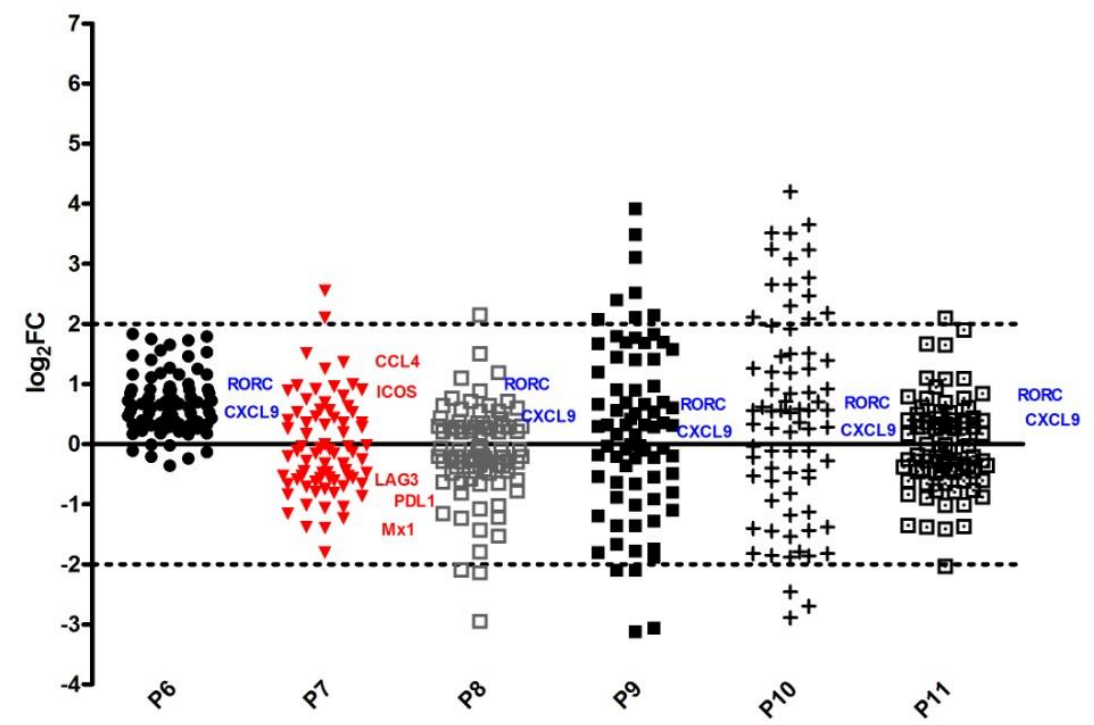

Figura 18 - Expressão relativa dos 86 genes analisados nos pacientes P7, P8, P9, P10 e P11 após 15 dias da primeira dose de imunoterapia (t1). Os dados foram representados na forma de $\log _{2} \mathrm{FC}$. A linha tracejada indica o intervalo escolhido para análise $\left(-2<\log _{2} \mathrm{FC}<2\right.$ equivalente a $\left.-4<\mathrm{FC}<4\right)$.

Quinze dias após receber a primeira dose da imunoterapia (t1) (figura 18), de acordo com o Genemania (APÊNDICE D), houve uma expressão aumentada de genes relacionados às proliferação de linfócitos (FDR: $4.25^{-4}$ ) e resposta imune adaptativa (FDR: $3.14^{-3}$ ). Ao mesmo tempo estavam menos expressos genes relacionados a resposta viral baseada em interferon do tipo I (FDR: $3,91^{-20}$ ).

Tabela 9 - Genes modulados após 15 dias da primeira dose de imunoterapia

\begin{tabular}{l|l|l}
\hline $\begin{array}{l}\text { Tipo de } \\
\text { modulação }\end{array}$ & $\begin{array}{l}\text { Genes regulados apenas nos } \\
\text { maus respondedores }\end{array}$ & $\begin{array}{l}\text { Genes regulados de maneira oposta P7 x maus } \\
\text { respondedores }\end{array}$ \\
\hline $\begin{array}{l}\text { Up } \\
\text { Down }\end{array}$ & $C X C L 9, R O R C$ & $\begin{array}{l}C C L 4, I C O S \\
L A G 3, M X 1, P D L 1\end{array}$ \\
\hline
\end{tabular}

Após 15 dias da segunda dose de imunoterapia (t2), ainda a maioria dos genes do P7 (77/86) apresentaram -4<FC<4 (Figura 16). Os genes CD25 (FC=1,31), IFI16 (FC=3,39), IL8 (FC=2,75), ISG15 (FC=2,28), STAT1 (FC=1,69), TAP1 (FC=1,78), IL7 (FC=0,34), PDL1 $(\mathrm{FC}=20,25)$, CD4OL (FC=0,67), EOMES $(\mathrm{FC}=0,90)$ estavam modulados de modo oposto no P7 comparado aos maus respondedores. Por outro lado, apenas os maus respondedores apresentaram a modulação para ICOS (média de FC=4,30) (Tabela 10). 


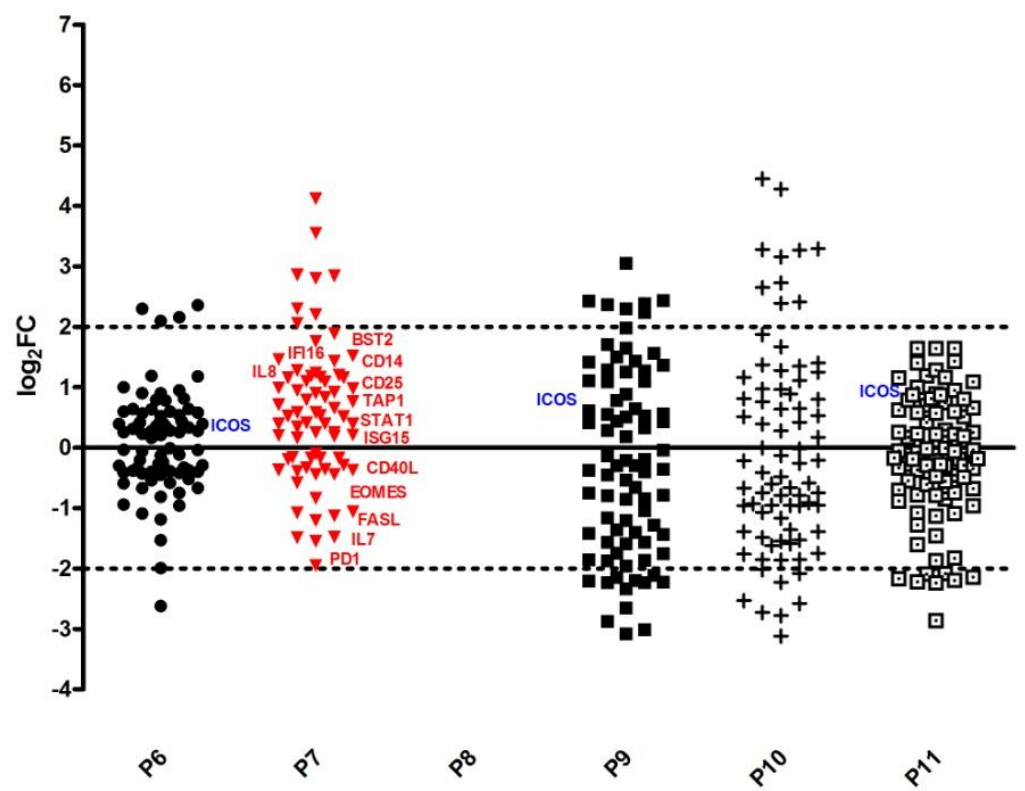

Figura 19 - Expressão relativa dos 86 genes analisados nos pacientes P7, P8, P9, P10 e P11 após 30 dias da primeira dose de imunoterapia (t2). Os dados foram representados na forma de FC. A linha tracejada indica o intervalo escolhido para análise $\left(-2<\log _{2} \mathrm{FC}<2\right.$ equivalente a $\left.-4<\mathrm{FC}<4\right)$.

Tabela 10 - Genes modulados após 30 dias da primeira dose de imunoterapia

\begin{tabular}{|c|c|c|}
\hline $\begin{array}{l}\text { Tipo de } \\
\text { modulação }\end{array}$ & $\begin{array}{l}\text { Genes regulados apenas nos maus } \\
\text { respondedores }\end{array}$ & $\begin{array}{l}\text { Genes regulados de maneira oposta P7 x } \\
\text { maus respondedores }\end{array}$ \\
\hline Up & ICOS & $\begin{array}{l}\text { BST2, CD14, CD25, IFI16, IL8, ISG15, STAT1, } \\
\text { TAP1 }\end{array}$ \\
\hline Down & & CD4OL, EOMES, FASL, IL7, PD1 \\
\hline
\end{tabular}

Após 30 dias da primeira dose (t2) (figura 19), de acordo com o Genemania (APÊNDICE D), ao contrário do que foi visto anteriormente, houve uma maior expressão de genes relacionados a resposta viral baseada em interferon do tipo I (FDR: $3,91^{-21}$ ) e uma menor expressão de genes relacionados a coestimulação de linfócitos (FDR: 3,19²), regulação positiva e ativação de células (FDR: $2,8^{-12}$ ).

Em t3, após 15 dias da terceira dose de imunoterapia, (figura 20) os dados apresentaram-se mais dispersos em relação aos outros tempos, principalmente nos pacientes P7 (73/86), P9 (73/86) e P10 (58/86). Os genes CCL4 (FC=1,56), CCL5 (FC=2,60), CCR7 $(\mathrm{FC}=4,38), \quad$ EOMES $\quad(\mathrm{FC}=1,46), \quad N K G 2 D \quad(\mathrm{FC}=3,53) \quad$ e $T I M 3 \quad(\mathrm{FC}=3,78) \quad$ estavam diferentemente modulados em P7 comparado aos maus respondedores. Os genes CCL2O (média de $\mathrm{FC}=2,88)$ e CNOT1 ( $\mathrm{FC}=0,77)$ estavam modulados nos mau respondedores (Tabela 11). É interessante reparar que no paciente $\mathrm{P} 7$, o gene $C N O T 1$ tem um $\mathrm{FC}=0,16$ que indica uma down regulação maior que maus respondedores e fora do nosso intervalo de análise. 


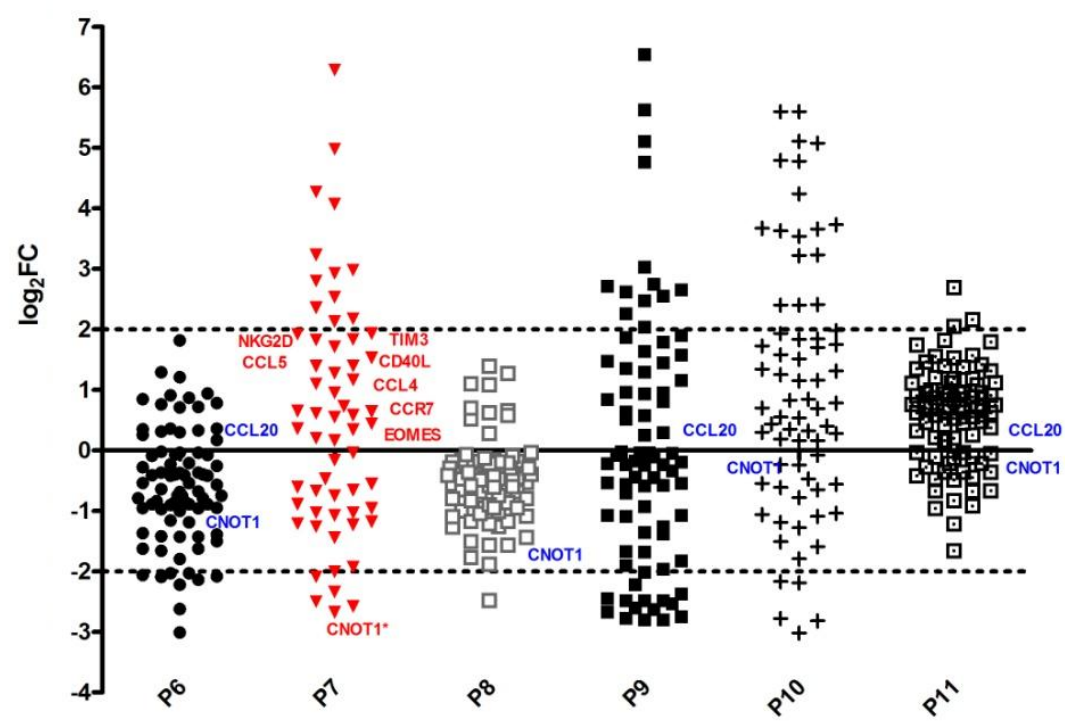

Figura 20 - Expressão relativa dos 86 genes analisados nos pacientes P7, P8, P9, P10 e P11 após 45 dias da primeira dose de imunoterapia (t3). Os dados foram representados na forma de $\log _{2} \mathrm{FC}$. A linha tracejada indica o intervalo escolhido para análise $\left(-2<\log _{2} \mathrm{FC}<2\right.$ equivalente a $\left.-4<\mathrm{FC}<4\right)$.

Tabela 11 - Genes modulados após 45 dias da primeira dose de imunoterapia

\begin{tabular}{l|l|l}
\hline $\begin{array}{l}\text { Tipo de } \\
\text { modulação }\end{array}$ & $\begin{array}{l}\text { Genes regulados apenas nos maus } \\
\text { respondedores }\end{array}$ & $\begin{array}{l}\text { Genes regulados de maneira oposta P7 x } \\
\text { maus respondedores }\end{array}$ \\
\hline Up & $C C L 20$ & CCL4, CCL5, CCR7, EOMES, NKG2D, TIM3 \\
Down & CNOT1 ${ }^{*}$ & - \\
\hline$* P 7-F C=0,16$. &
\end{tabular}

Passados 45 dias da primeira intervenção (t3), foi vista no bom respondedor maior expressão de genes envolvidos na ativação de células T (FDR: 2,29-11), citotoxicidade mediada por NK (FDR: 2,29 ${ }^{-11}$ ) e quimiotaxia de leucócitos (FDR: 2,29 $9^{-11}$ ) (APÊNDICE D).

Para destacar a modulação dos genes selecionados ao longo do tratamento em P7 e nos maus respondedores, os dados de expressão relativa nos 3 tempos analisados $(t 1, t 2, t 3)$ foram reportados em heat maps (Figura 21). As setas brancas representam os dados fora do intervalo escolhido para análise, ou seja, valores $\mathrm{FC}<-4$ e $>4\left(\log _{2} \mathrm{FC}<-2\right.$ e $\left.<2\right)$. Sendo que a seta para cima indica $\mathrm{FC}>4$ e seta para baixo, $\mathrm{FC}<-4$. 

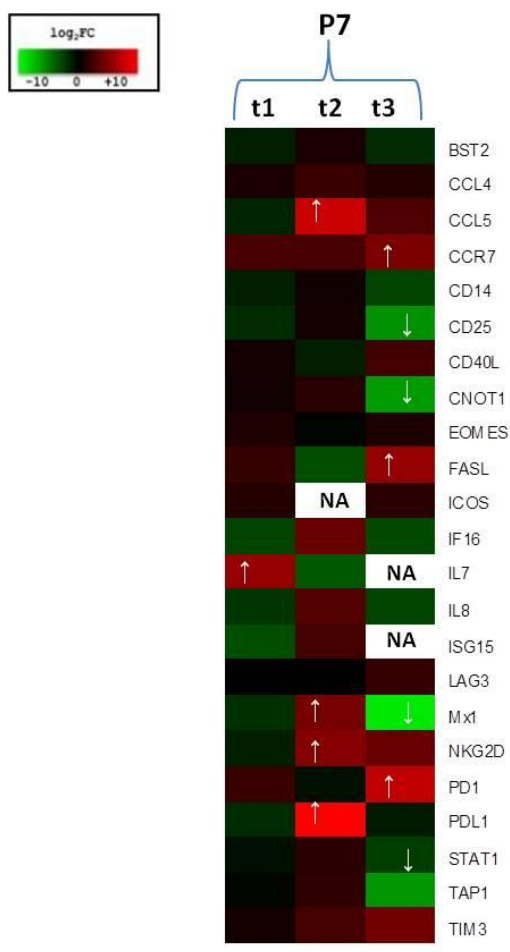

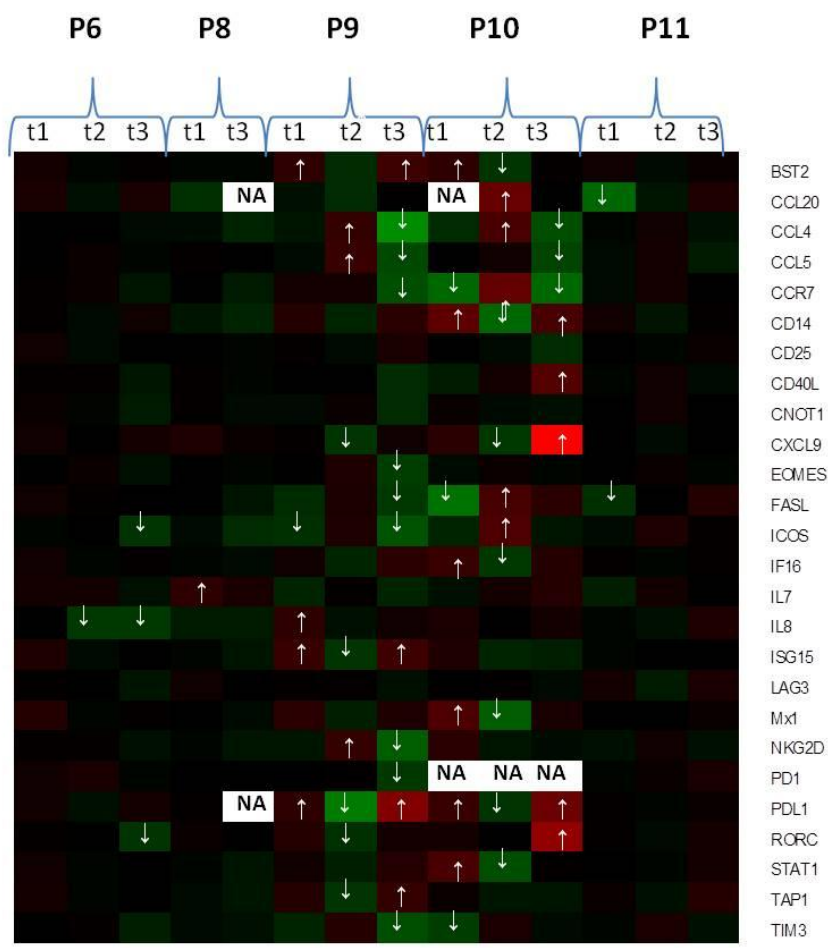

Figura 21 - Heat map dos genes diferentemente expressos nos 3 tempos analisados. São reportados valores de $\log _{2} \mathrm{FC}$ resultantes da comparação dos PBMC após a imunoterapia (t1, t2 e t3) contra os PBMC antes da terapia (t0) para o paciente P7 e para os pacientes P6, P8, P9, P10 e P11. Abreviaturas - NA: não amplificou

O paciente P7 apresentou uma mudança de sentido na modulação da expressão gênica após $\mathrm{t} 2$, ou seja, os genes passaram de mais expressos para menos expressos e vice-versa, com exceção de $C C L 4, C C L 5, C C R 7$ e TIM3. Em quase todos os genes a modulação de t1 e t3 tiveram o mesmo sentido.

Em relação aos maus respondedores esse tipo de resposta contrária em t2 foi observada também.

Em relação aos genes que foram modulados apenas nos maus respondedores (Figura 22), vimos novamente esse tipo de resposta, onde o sentido da modulação muda em t2. Os pacientes apresentam muitas diferenças entre si, em destaque o paciente P10 que parece modular de forma diferente a maioria dos genes. 


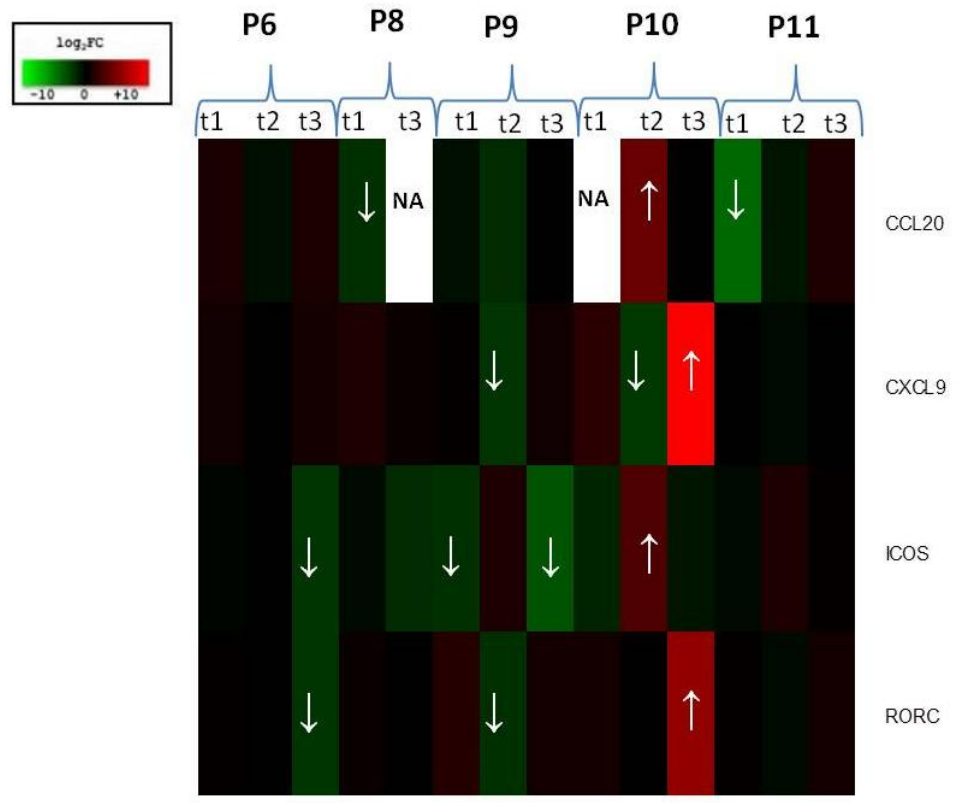

Figura 22 - Heat map dos genes diferentemente expressos apenas nos maus respondedores nos 3 tempos analisados . São reportados valores de $\log _{2} \mathrm{FC}$ resultantes da comparação dos PBMC após a imunoterapia (t1, t2 e t3) contra os PBMC antes da terapia (t0) para o paciente $\mathrm{P} 7$ e para os pacientes P6, P8, P9, P10 e P11.

\subsection{Modulação da expressão dos genes NOS1 e MBL2 em PBMC após a imunoterapia}

Considerando os resultados de associação entre SNP nos genes NOS1 (rs693534) e MBL2 (rs10824) e a resposta à imunoterapia do ensaio de fase I da UFPE (SEGAT et al., 2010), analisamos a expressão desses dois genes nos PBMC antes e após a imunoterapia, porém não conseguimos verificar a amplificação de NOS1 e MBL2 nas amostras de PBMC analisadas. 


\subsection{Modulação da expressão dos gene do inflamassoma em PBMC após a imunoterapia}

Considerando dados previamente reportados sobre a expressão constitutiva de genes do inflamassoma em células dendríticas de pacientes HIV+ (PONTILLO; SILVA; et al., 2012) foi avaliada a expressão de genes do inflamassoma IL1B, CASP1 e IL18 nos leucócitos circulantes dos indivíduos submetidos à imunoterapia com um ensaio de sonda específica.

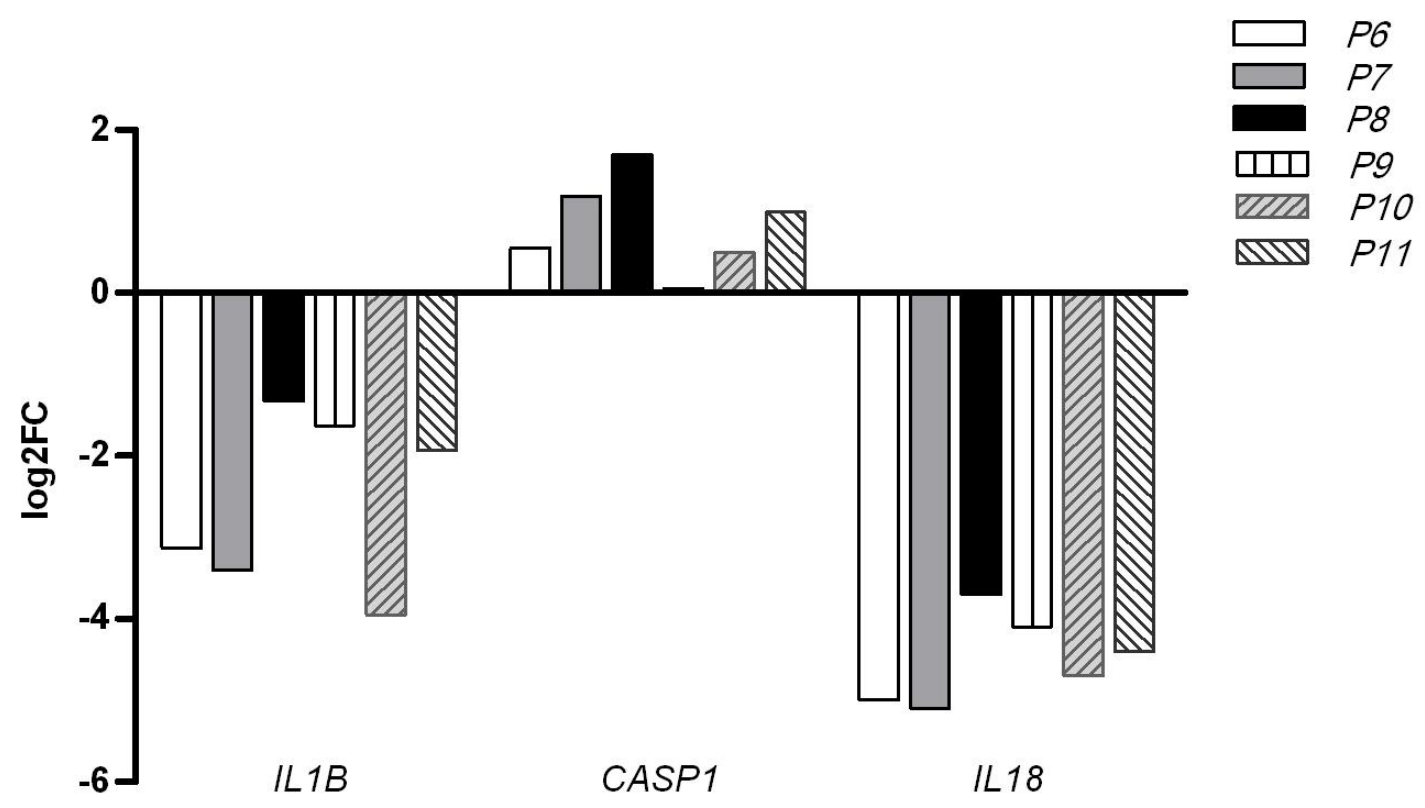

Figura 23 - Expressão gênica relativa de genes relacionados ao inflamassoma. São representados os valores de $\log 2 \mathrm{FC}$ das amostra em t1. A análise estatística foi feita no software GraphPad Prism®, mediante o teste Two-Way Anova, seguido do pós-teste de Bonferroni.

Foi observada a modulação de IL1B, IL18 e CASP1 em leucócitos dos pacientes submetidos à imunoterapia (figura 23), de acordo com dados previamente publicados (PONTILLO; SILVA; et al., 2012). O gene da IL18 não mostrou diferenças entre os pacientes maus respondedores e o bom respondedor.

A avaliação da modulação da expressão gênica dos pacientes HIV+ submetidos à imunoterapia revelou que o $\mathrm{P} 7$, único bom respondedor do protocolo, não expressa nenhuma gene de modo exclusivo em nenhum dos tempos estudados, porém modula de forma diferente alguns genes comparado com os indivíduos que não responderam ao tratamento. De outro lado os maus respondedores modulam a expressão de alguns genes de modo exclusivo. 


\subsection{Discussão: PBMC de indivíduos submetidos à imunoterapia}

Na segunda parte do projeto, avaliamos a modulação da expressão gênica nos PBMC de 6 pacientes submetidos à imunoterapia. Desses 6 pacientes (P6-P11), um único indivíduo, P7, resultou responsivo ao tratamento (bom respondedor, $\Delta \mathrm{CVP}>1 \log$ ).

Não esperando encontrar modulações agudas da expressão gênica induzida pela imunoterapia nos PBMC após 15 dias escolhemos uma estratégia de análise diferente em comparação a análise feita na parte I, em vez de modulação "extremas" ( $|\mathrm{FC}|>4)$, consideramos modulações menores $(|\mathrm{FC}|<4)$, de acordo com trabalhos semelhantes (HAGAN et al., 2015; NAKAYA; PULENDRAN, 2015).

A análise de agrupamento hierárquico dos dados de expressão gênica mostrou a segregação do perfil dos PBMC do P7 em relação aos maus respondedores em todos os tempos analisados (Figuras 16,17,18), sugerindo que o perfil gênico avaliado está relacionado com a resposta à imunoterapia. Em nenhum dos tempos considerados, os PBMC do P7 apresentaram a expressão exclusiva de algum dos genes investigados, porém em cada tempo P7 apresentou alguns genes diferencialmente modulados comparado com os maus respondedores (Tabelas 9, 10 e 11).

Quinze dias após receber a primeira dose da imunoterapia (t1), nos PBMC de P7 foi vista uma aumentada expressão de CCL4 e ICOS. CCL4/ MIP-1b é uma quimiocina capaz de se ligar à CCR5 e competir pela ligação com o vírus HIV-1 (COCCHI et al., 1995; SAMSON et al., 1996), sugerindo que o aumento de expressão observado no P7 seria importante para diminuir a replicação do HIV-1 nesse paciente. A sinalização de ICOS está relacionada com a expansão de células T efetoras (JURADO et al., 2012; LOKE; ALLISON, 2004), indicando que o P7 apresenta uma indução de genes associados a ativação de resposta imune específica. $L A G 3$, MX1 e PDL1, genes relacionados à resposta viral baseada em interferon do tipo I, encontram-se menos expressos em $\mathrm{t} 1$ comparado com t0. LAG3 já foi relacionado com a exaustão de linfócitos T CD8+ na infecção pelo HIV-1 (YAMAMOTO et al., 2011). Uma vez que a expressão desse gene no P7 estava diminuída, isso poderia estar relacionado com uma menor exaustão do sistema imune nesse paciente, ou seja, com uma melhor capacidade de ativação imune. Por outro lado, Pena et al., (2014) viram que a expressão aumentada desse gene em células T CD8+ está correlacionada inversamente com a carga viral plasmática, sugerindo assim efeito de controle viral.

No $\mathrm{t} 1$, os pacientes maus respondedores (P6, P8, P9, P10 e P11) mostraram uma modulação exclusiva de 2 genes, CXCL9 (expressão aumentada) e RORC (expressão 
diminuída). O CXCL9 é induzido na resposta anti-HIV (HYRCZA et al., 2007). A expressão aumentada de $R O R C$, fator de transcrição específico para a subpopulação Th17, poderia indicar uma maior diferenciação de células T CD4+ para a subpopulação Th17 nesses pacientes. Em pacientes que progridem para AIDS sabe-se que ocorre uma grande perda de células Th17 (GUILLOT-DELOST et al., 2012), no entanto como essa subpopulação, de modo geral, pode estar associada tanto com respostas protetivas quando prejudiciais e sua função na infecção pelo HIV-1 não está caracterizada completamente, esse aumento de expressão de RORC nos maus respondedores não é tão informativo.

Após 30 dias da primeira dose (t2), e após 15 dias da secunda dose, nos PBMC do P7 foi visto um aumento da expressão de genes relacionados à resposta viral baseada em interferon do tipo I (BST-2/tetherin, CD14, CD25, IFI16, IL8, ISG15, STAT1, TAP1), o mesmo não se observou nos maus respondedores. Uma expressão elevada de CD14 na superfície celular foi previamente associada a uma capacidade de controlar a replicação do HIV-1 em controladores de elite (KRISHNAN et al., 2014), sugerindo que a maior expressão do gene $C D 14$ vista em P7 poderia estar associada a um controle melhor da carga viral nesse paciente. Raposo et al., (2013) viram uma alta indução da expressão de BST-2/tetherin e ISG15 em PBMC de doadores saudáveis ativados in vitro com o vírus HIV-1. Além disso, foi visto que a expressão de $B S T$-2 correlaciona negativamente com a infectividade do HIV-1 (KUHL et al., 2010). A alta carga viral em pacientes HIV+ estaria associada a uma menor expressão de CD25 em Treg e isso poderia afetar a capacidade de expansão dessas células em resposta ao IL-2 produzido por células T CD4+ (READ et al., 2006). Em nossos dados, o paciente de melhor resposta à imunoterapia, mostrou uma alta expressão do gene $C D 25$, o que poderia estar relacionado com uma função de Treg mais preservada.

IFI16 é uma proteína sensor de DNA induzível pelo IFN- $\gamma$ capaz de induzir a transcrição de genes de IFNs de tipo I e também a ativação do inflamassoma. Recentes estudos mostraram que o nível de expressão do IFI16 está aumentado em pacientes HIV+ naïves de tratamento antirretroviral (NISSEN et al., 2014) e que IFI16 medeia a morte inflamassoma-dependente dos linfócitos CD4+ infectados por HIV-1 (MONROE et al., 2014). O indivíduo P7 apresentou um aumento na expressão desse gene em t2, sugerindo que isso pode estar ligado tanto com o aumento observado dos genes da assinatura de interferon (Tabela 10), tanto com a ativação do inflamassoma. Esse dado está em acordo com o resultado da expressão de outros genes do inflamassoma analisados, IL1B, IL18 (Figura 23) que se encontra aumentada exclusivamente nesse paciente.

STAT1 é conhecido por mediar a expressão de outros genes envolvidos na viabilidade 
celular, enquanto TAP1 está envolvido na apresentação de antígenos para linfócitos. Em nossos dados, STATl e TAPl estavam mais expressos em P7, sugerindo uma melhor conservação das funções imunes nesse paciente.

No t2, P7 mostrou uma diminuição da expressão de CD4OL, EOMES, FASL, IL7, PD1. A expressão de superfície aumentada de CD40L e PD1 foi vista em controladores de elite (WHITTALL et al., 2011), no entanto quando consideramos os outros tempos, vimos que essa diminuição da expressão foi apenas transitória e possivelmente não está relacionada com aumento de progressão da doença. A expressão de $F A S L$, relacionado à capacidade citotóxica, também apresentou o mesmo comportamento, ou seja, teve uma diminuição apenas em t2. Olhando os demais tempos, não houve co-expressão com FAS no PBMC desse paciente, sugerindo que a apoptose não parece estar aumentada nesse paciente. A IL-7 é conhecida por seus efeitos anti-apoptóticos e proliferativos em células. Na infecção pelo HIV1 os níveis dessa citocina encontram-se altos e isso pode contribuir para a diminuição da expressão do seu receptor CD127 (O'CONNOR; CRAWLEY; ANGEL, 2010). Em relação à expressão gênica, IL7 estava menos expresso no bom respondedor, mostrando um padrão mais próximo a indivíduos não infectados.

Em t2, os maus respondedores mostraram um aumento exclusivo da expressão de ICOS, o que em 11 foi visto apenas em P7.

Passados 45 dias da primeira intervenção e após 15 dias da terceira dose (t3), foi vista no bom respondedor uma aumentada expressão dos genes EOMES e TIM3, envolvidos na ativação de células T, $N K G 2 D$, que medeia a citotoxicidade mediada por NK e CCL4, CCL5, CCR7. Como já foi mencionado acima, um aumento de CCL4 e CCL5, quimiocinas que competem com HIV-1 para a ligação com o correceptor CCR5, seria um bom prognóstico com relação ao controle viral (COCCHI et al., 1995; SAMSON et al., 1996).

Em 2014, pesquisadores viram que o HIV-1+ diminui a expressão de superfície de CCR7, o que compromete a migração e a sinalização quimiotática em células T CD4+ (RAMIREZ et al., 2014). Essa aumentada expressão do CCR7 pode sugerir que o P7 consegue manter características importantes para a função do sistema imune ao contrário dos outros pacientes.

Indivíduos HIV+ não-progressores e controladores de elite apresentam células NK com uma alta expressão de NKG2D (MARRAS et al., 2013). Dessa forma a expressão desse gene seria benéfica, o que é consistente com a aumentada expressão de $N K G 2 D$ observada no P7 ao t3. 
O paciente P7 mostrou uma diminuição (t2) e um aumento (t3) da expressão de EOMES ao longo do seguimento vacinal. A diminuída expressão de EOMES foi associada com o declínio de células T CD8+ funcionais (RIBEIRO-DOS-SANTOS et al., 2012). No entanto a função desse marcador ainda não está bem esclarecida, e em nossos dados não conseguimos entender a modulação desse gene em relação com a resposta a imunoterapia.

Em relação a TIM3, células que expressam essa molécula apresentam um disfunção na proliferação e produção de citocinas (ZHANG et al., 2015). Essa exaustão relacionada a TIM3 não seria interessante em termos de resposta à imunoterapia, de modo que não conseguimos explicar um aumento de expressão do gene TIM3 no P7.

Em t3, os maus respondedores mostraram a expressão exclusiva de 2 genes CCL2O (aumentada) e CNOT1 (diminuída). O gene CNOT1 já foi correlacionado com uma má resposta ao tratamento nos pacientes submetidos à imunoterapia de Lu et al. (2004) (MOURA et al., 2014). Em nossos pacientes maus respondedores, foram vistos baixos níveis de expressão desse gene, no entanto no P7 essa expressão era menor ainda $(\mathrm{FC}<-4)$, o que seria benéfico em nosso contexto.

É importante ressaltar que alguns genes diferencialmente expressos no P7 e nos maus respondedores foram também relacionados com resposta à vacinas preventivas. A vacina de varíola induz a expressão dos genes CCL20, ISG15, FASL em PBMC (HARALAMBIEVA et al., 2012) que também foram modulados na imunoterapia. Em resposta às vacinações com o vírus vaccínia e o vírus da febre amarela (SCHERER et al., 2007) foram vistos aumentos de expressão nos genes STAT1 e ISG15.

Em estudos de resposta a diferentes tipos de imunoterapia, como a utilizada em paciente com câncer, também observou-se a modulação de genes expressos nos nossos pacientes. $\mathrm{O}$ aumento de expressão dos genes CCLA e CCL5 foi visto em linfócitos do sangue periférico de pacientes com carcinoma renal tratados com imunoterapia (WOLF et al., 2012), indicando uma modulação da expressão dos PBMC não relacionada diretamente com a imunoterapia contra o HIV-,1 mas a um mecanismo mais geral de resposta imune.

Apesar de sugerir todas essas relações entre nossos resultados e o efeito em pacientes HIV-1+, é importante considerar que o uso de PBMCs pode limitar interpretações por causa da diluição e pode não refletir o perfil gênico das subpopulações individuais (BRYANT et al., 2009). 


\section{RESULTADOS E DISCUSSÃO- PARTE III}

\subsection{Genotipagem dos pacientes submetidos à imunoterapia}

\subsubsection{Polimorfismos de base única previamente associados à resposta a imunoterapia para indivíduos HIV+}

Considerando resultados anteriores do nosso grupo em relação ao perfil genômico da resposta à imunoterapia e a identificação de polimorfismos em genes da imunidade inata (NOS1, MBL2) associados com a resposta ao tratamento (SEGAT et al., 2010), foram analisados os polimorfismos rs693534 no gene NOS1 e rs10824 no gene MBL2 nos 11 indivíduos HIV+ estudados (P1-P11). As características dos SNPs estão reportados na tabela 12.

\section{Tabela 12 - Descrição dos genes avaliados nesse trabalho}

\begin{tabular}{c|c|c|c}
\hline Genes & Polimorfismo & Alelos & MAF* $^{*}$ \\
\hline NOS1 & rs693534 & $\mathrm{G}>\mathrm{A}$ & $\mathrm{A}: 0.36$ \\
\hline MBL2 & rs10824 & $\mathrm{C}>\mathrm{T}$ & $\mathrm{T}:-$ \\
\hline
\end{tabular}

*Minor allele frequency

A genotipagem resultou nos dados apresentados na tabela 13. Apenas para o indivíduo P11 não temos todos os dados de amplificação apesar de ter repetido o experimento várias vezes.

Tabela 13 - Polimorfismos previamente associados à resposta a imunoterapia nos 11 pacientes utilizados no trabalho

\begin{tabular}{l|l|l|l|l|l|l|l|l|l|l|l|l}
\hline Genes & SNP ID & P1 & P2 & P3 & P4 & P5 & P6 & P7 & P8 & P9 & P10 & P11 \\
\hline NOS1 & $\mathrm{rs693534}$ & $\mathrm{A} / \mathrm{G}$ & $\mathrm{A} / \mathrm{A}$ & $\mathrm{A} / \mathrm{G}$ & $\mathrm{G} / \mathrm{G}$ & $\mathrm{A} / \mathrm{G}$ & $\mathrm{A} / \mathrm{G}$ & $\mathrm{A} / \mathrm{G}$ & $\mathrm{A} / \mathrm{G}$ & $\mathrm{A} / \mathrm{G}$ & $\mathrm{A} / \mathrm{G}$ & $\mathrm{A} / \mathrm{G}$ \\
\hline MBL2 & $\mathrm{rs} 10824$ & $\mathrm{C} / \mathrm{T}$ & $\mathrm{C} / \mathrm{C}$ & $\mathrm{C} / \mathrm{T}$ & $\mathrm{C} / \mathrm{T}$ & $\mathrm{C} / \mathrm{T}$ & $\mathrm{C} / \mathrm{C}$ & $\mathrm{C} / \mathrm{T}$ & $\mathrm{C} / \mathrm{T}$ & $\mathrm{C} / \mathrm{T}$ & $\mathrm{C} / \mathrm{C}$ & $\mathrm{C} / \mathrm{T}$ \\
\hline
\end{tabular}

O P7 carrega um alelo polimórfico dos 2 SNPs, no entanto os outros pacientes HIV+ que não responderam à imunoterapia também carregam, sendo assim não dá para confirmar o dado de associação entre esses dois SNPs e a resposta a imunoterapia (SEGAT et al., 2010).

Quando tentamos associar esses dados com a variação de CD4+ e CVP (Figura 24), 
vimos que o SNP rs693534 no gene NOS1 mostrou uma associação entre o genótipo A/G e um aumento na contagem de linfócitos T CD4+ e uma diminuição na CVP nos pacientes vacinados. Da mesma forma o SNP rs10824 no gene MBL2 mostrou a mesma associação. No entanto essas associações não foram estatisticamente significantes.
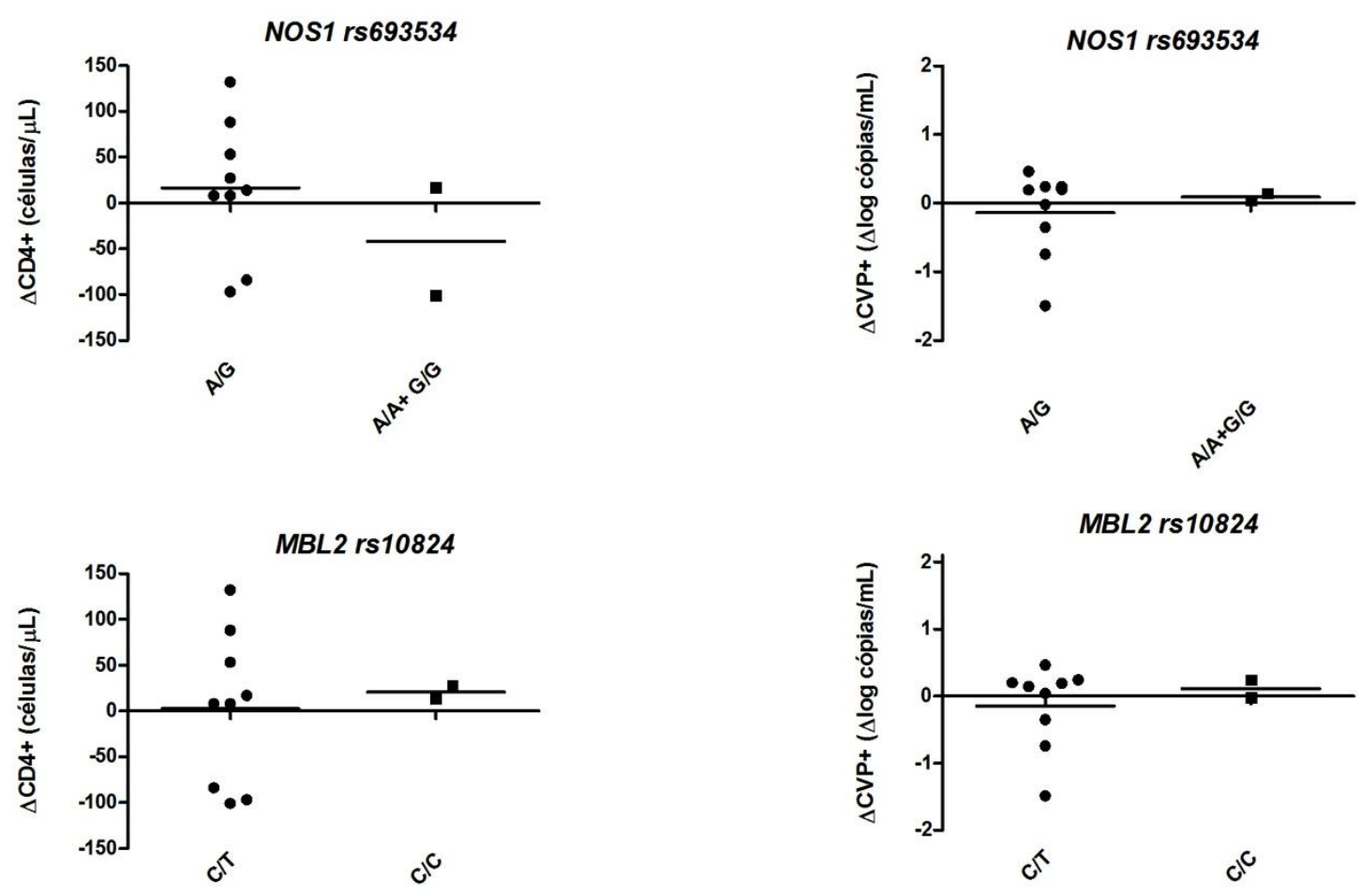

Figura 24 - Nível plasmático de linfócitos CD4+ e redução da carga viral plasmática (CVP) em 11 pacientes em t3 em acordo com os genótipos de NOS1 rs693534 e MBL2 rs10824. Os dados foram analisados com t-test. ${ }^{*} \mathrm{p}<0,05$.

\subsubsection{Polimorfismos em fatores de restrição para o HIV-1}

Nos 11 indivíduos HIV+ estudados foram analisados polimorfismos para fatores de restrição para o HIV-1 (APOBEC3G, CCL3,CCL4, CCL5, CCR5, CUL5, CXCR6, HLA-C, IFNG, PARD3B, PROX1, CXCR6,CXCL12, TRIM5, ZNRD1) previamente analisados na fase I do mesmo ensaio clínico de Lu et al. (2004) (PONTILLO et al., 2014). As características dos polimorfismos são reportados na tabela 14 . 
Tabela 14 - Descrição dos polimorfismos em fatores de restrição para o HIV-1

\begin{tabular}{|c|c|c|c|}
\hline Genes & Polimorfismo & Alelos & MAF* \\
\hline \multirow[t]{2}{*}{ APOBEC $3 G$} & rs3736685 & $\mathrm{T}>\mathrm{C}$ & C: 0.03 \\
\hline & rs2294367 & $\mathrm{G}>\mathrm{C}$ & C: 0.42 \\
\hline CCL3 & rs1719134 & $G>A$ & A: 0.24 \\
\hline CCLA & rs1719153 & $\mathrm{A}>\mathrm{T}$ & T: 0.28 \\
\hline \multirow[t]{2}{*}{ CCL5 } & rs2280789 & $A>G$ & G: 0.10 \\
\hline & rs2107538 & $\mathrm{C}>\mathrm{T}$ & T: 0.18 \\
\hline CCR5 & $\Delta 32$ & $\mathrm{Wt}>\Delta 32$ & - \\
\hline \multirow[t]{3}{*}{ CUL5 } & rs7117111 & $\mathrm{G}>\mathrm{A}$ & A: 0.40 \\
\hline & rs11212495 & $A>G$ & G: 0.12 \\
\hline & rs7103534 & $\mathrm{C}>\mathrm{T}$ & C: 0.13 \\
\hline CXCR6 & rs2234358 & $\mathrm{T}>\mathrm{G}$ & T: 0.41 \\
\hline \multirow[t]{2}{*}{$H L A-C$} & rs10484554 & $\mathrm{C}>\mathrm{T}$ & T: 0.13 \\
\hline & rs9264942 & $\mathrm{T}>\mathrm{C}$ & C: 0.34 \\
\hline$I F N G$ & rs2069709 & $\mathrm{A}>\mathrm{C}$ & A: -0.06 \\
\hline PARD3B & rs11884476 & $\mathrm{C}>\mathrm{G}$ & G: 0.04 \\
\hline PROXI & rs17762192 & $\mathrm{G}>\mathrm{C}$ & C: 0.42 \\
\hline CXCL12 & rs1801157 & $\mathrm{T}>\mathrm{C}$ & C: 0.40 \\
\hline \multirow[t]{3}{*}{ TRIM5 } & rs16934386 & $A>G$ & - \\
\hline & rs10838525 & $\mathrm{C}>\mathrm{T}$ & T: 0.37 \\
\hline & rs3740996 & $G>A$ & A: 0.13 \\
\hline ZNRDI & rs3869068 & $\mathrm{C}>\mathrm{T}$ & T: 0.08 \\
\hline
\end{tabular}

Na tabela 15 são reportados os resultados da genotipagem. Para o indivíduo P11 não temos todos os dados de amplificação apesar de ter repetido o experimento várias vezes. 
Tabela 15 - Polimorfismos em genes de fatores de restrição ao HIV nos 11 pacientes utilizados no trabalho

\begin{tabular}{|c|c|c|c|c|c|c|c|c|c|c|c|c|}
\hline Genes & Polimorfismo & $\mathbf{P 1}$ & $\mathbf{P 2}$ & $\mathbf{P 3}$ & P4 & P5 & P6 & P7 & $\mathbf{P 8}$ & P9 & P10 & P11 \\
\hline \multirow[t]{2}{*}{ APOBEC $3 G$} & rs3736685 & $\mathrm{T} / \mathrm{T}$ & $\mathrm{T} / \mathrm{T}$ & $\mathrm{C} / \mathrm{T}$ & $\mathrm{T} / \mathrm{T}$ & $\mathrm{T} / \mathrm{T}$ & $\mathrm{T} / \mathrm{T}$ & $\mathrm{T} / \mathrm{T}$ & $\mathrm{T} / \mathrm{T}$ & $\mathrm{C} / \mathrm{T}$ & $\mathrm{C} / \mathrm{T}$ & $\mathrm{N}$ \\
\hline & rs2294367 & $\mathrm{C} / \mathrm{G}$ & $\mathrm{C} / \mathrm{G}$ & $\mathrm{C} / \mathrm{G}$ & $\mathrm{C} / \mathrm{G}$ & $\mathrm{G} / \mathrm{G}$ & $\mathrm{C} / \mathrm{C}$ & $\mathrm{C} / \mathrm{G}$ & $\mathrm{C} / \mathrm{G}$ & $\mathrm{C} / \mathrm{G}$ & $\mathrm{C} / \mathrm{G}$ & $\mathrm{C} / \mathrm{G}$ \\
\hline$C C L 3$ & rs1719134 & $\mathrm{A} / \mathrm{G}$ & $\mathrm{G} / \mathrm{G}$ & $\mathrm{A} / \mathrm{G}$ & $\mathrm{G} / \mathrm{G}$ & $\mathrm{G} / \mathrm{G}$ & $\mathrm{A} / \mathrm{G}$ & $\mathrm{G} / \mathrm{G}$ & $\mathrm{G} / \mathrm{G}$ & $\mathrm{G} / \mathrm{G}$ & $\mathrm{G} / \mathrm{G}$ & $\mathrm{N}$ \\
\hline CCL4 & rs1719153 & $\mathrm{T} / \mathrm{T}$ & $\mathrm{A} / \mathrm{A}$ & $\mathrm{A} / \mathrm{T}$ & $\mathrm{A} / \mathrm{T}$ & $\mathrm{A} / \mathrm{T}$ & $\mathrm{T} / \mathrm{T}$ & $\mathrm{A} / \mathrm{T}$ & $\mathrm{A} / \mathrm{T}$ & $\mathrm{A} / \mathrm{T}$ & $\mathrm{A} / \mathrm{T}$ & $\mathrm{N}$ \\
\hline \multirow[t]{2}{*}{$C C L 5$} & rs2280789 & $\mathrm{A} / \mathrm{G}$ & $\mathrm{A} / \mathrm{G}$ & $\mathrm{A} / \mathrm{A}$ & $\mathrm{A} / \mathrm{A}$ & $\mathrm{A} / \mathrm{A}$ & $\mathrm{A} / \mathrm{A}$ & G/G & $\mathrm{A} / \mathrm{G}$ & $\mathrm{A} / \mathrm{A}$ & $\mathrm{A} / \mathrm{A}$ & $\bar{N}$ \\
\hline & rs2107538 & $\mathrm{C} / \mathrm{T}$ & $\mathrm{C} / \mathrm{T}$ & $\mathrm{C} / \mathrm{C}$ & $\mathrm{C} / \mathrm{T}$ & $\mathrm{C} / \mathrm{C}$ & $\mathrm{C} / \mathrm{C}$ & $\mathbf{T} / \mathbf{T}$ & $\mathrm{T} / \mathrm{T}$ & $\mathrm{C} / \mathrm{C}$ & $\mathrm{C} / \mathrm{T}$ & $\mathrm{N}$ \\
\hline CCR5 & $\Delta 32$ & $\mathrm{wt} / \mathrm{wt}$ & $\mathrm{wt} / \mathrm{wt}$ & $\mathrm{wt} / \mathrm{wt}$ & $\mathrm{wt} / \mathrm{wt}$ & $\mathrm{wt} / \mathrm{wt}$ & $\mathrm{wt} / \mathrm{wt}$ & $\mathrm{wt} / \mathrm{wt}$ & $\mathrm{wt} / \mathrm{wt}$ & $\mathrm{wt} / \mathrm{wt}$ & $\mathrm{wt} / \mathrm{wt}$ & $\mathrm{wt} / \mathrm{wt}$ \\
\hline \multirow[t]{3}{*}{ CUL5 } & rs7117111 & $\mathrm{A} / \mathrm{G}$ & $\mathrm{A} / \mathrm{G}$ & $\mathrm{A} / \mathrm{G}$ & $\mathrm{A} / \mathrm{A}$ & $\mathrm{A} / \mathrm{A}$ & $\mathrm{G} / \mathrm{G}$ & $\mathrm{G} / \mathrm{G}$ & $\mathrm{G} / \mathrm{G}$ & $\mathrm{A} / \mathrm{G}$ & $\mathrm{A} / \mathrm{A}$ & $\mathrm{N}$ \\
\hline & rs11212495 & $\mathrm{A} / \mathrm{A}$ & $\mathrm{G} / \mathrm{G}$ & $\mathrm{A} / \mathrm{A}$ & $\mathrm{A} / \mathrm{A}$ & $\mathrm{A} / \mathrm{A}$ & $\mathrm{A} / \mathrm{A}$ & $\mathrm{A} / \mathrm{A}$ & $\mathrm{A} / \mathrm{G}$ & $\mathrm{A} / \mathrm{A}$ & $\mathrm{A} / \mathrm{A}$ & $\mathrm{N}$ \\
\hline & rs7103534 & $\mathrm{T} / \mathrm{T}$ & $\mathrm{T} / \mathrm{T}$ & $\mathrm{T} / \mathrm{T}$ & $\mathrm{C} / \mathrm{T}$ & $\mathrm{C} / \mathrm{T}$ & $\mathrm{T} / \mathrm{T}$ & $\mathrm{T} / \mathrm{T}$ & $\mathrm{T} / \mathrm{T}$ & $\mathrm{C} / \mathrm{T}$ & $\mathrm{C} / \mathrm{T}$ & $\mathrm{N}$ \\
\hline CXCR6 & rs2234358 & $\mathrm{T} / \mathrm{T}$ & $\mathrm{T} / \mathrm{T}$ & $\mathrm{G} / \mathrm{G}$ & $\mathrm{G} / \mathrm{T}$ & $\mathrm{G} / \mathrm{T}$ & $\mathrm{G} / \mathrm{T}$ & $\mathrm{G} / \mathrm{T}$ & $\mathrm{G} / \mathrm{T}$ & $\mathrm{G} / \mathrm{G}$ & $\mathrm{G} / \mathrm{T}$ & $\mathrm{N}$ \\
\hline \multirow[t]{2}{*}{$H L A-C$} & rs10484554 & $\mathrm{C} / \mathrm{C}$ & $\mathrm{C} / \mathrm{C}$ & $\mathrm{C} / \mathrm{C}$ & $\mathrm{C} / \mathrm{C}$ & $\mathrm{T} / \mathrm{T}$ & $\mathrm{C} / \mathrm{C}$ & $\mathrm{C} / \mathrm{T}$ & $\mathrm{T} / \mathrm{T}$ & $\mathrm{C} / \mathrm{C}$ & $\mathrm{C} / \mathrm{C}$ & $\mathrm{N}$ \\
\hline & rs9264942 & $\mathrm{C} / \mathrm{T}$ & $\mathrm{C} / \mathrm{T}$ & $\mathrm{C} / \mathrm{T}$ & $\mathrm{C} / \mathrm{C}$ & $\mathrm{C} / \mathrm{T}$ & $\mathrm{C} / \mathrm{T}$ & $\mathrm{C} / \mathrm{T}$ & $\mathrm{C} / \mathrm{C}$ & $\mathrm{C} / \mathrm{T}$ & $\mathrm{T} / \mathrm{T}$ & $\mathrm{N}$ \\
\hline IFNG & rs2069709 & $\mathrm{C} / \mathrm{C}$ & $\mathrm{C} / \mathrm{C}$ & $\mathrm{C} / \mathrm{C}$ & $\mathrm{C} / \mathrm{C}$ & $\mathrm{C} / \mathrm{C}$ & $\mathrm{C} / \mathrm{C}$ & $\mathrm{C} / \mathrm{C}$ & $\mathrm{C} / \mathrm{C}$ & $\mathrm{C} / \mathrm{C}$ & $\mathrm{C} / \mathrm{C}$ & $\mathrm{N}$ \\
\hline PARD3B & rs11884476 & $\mathrm{C} / \mathrm{C}$ & $\mathrm{C} / \mathrm{G}$ & $\mathrm{C} / \mathrm{C}$ & $\mathrm{C} / \mathrm{C}$ & $\mathrm{C} / \mathrm{C}$ & $\mathrm{C} / \mathrm{C}$ & $\mathrm{C} / \mathrm{G}$ & $\mathrm{C} / \mathrm{C}$ & $\mathrm{C} / \mathrm{C}$ & $\mathrm{C} / \mathrm{C}$ & $\mathrm{N}$ \\
\hline PROXI & rs17762192 & $\mathrm{G} / \mathrm{G}$ & $\mathrm{G} / \mathrm{G}$ & $\mathrm{C} / \mathrm{C}$ & $\mathrm{C} / \mathrm{G}$ & $\mathrm{C} / \mathrm{G}$ & $\mathrm{C} / \mathrm{G}$ & $\mathrm{C} / \mathrm{G}$ & $\mathrm{C} / \mathrm{G}$ & $\mathrm{G} / \mathrm{G}$ & $\mathrm{C} / \mathrm{G}$ & $\mathrm{N}$ \\
\hline CXCL12 & rs1801157 & $\mathrm{C} / \mathrm{C}$ & $\mathrm{C} / \mathrm{C}$ & $\mathrm{C} / \mathrm{T}$ & $\mathrm{C} / \mathrm{T}$ & $\mathrm{C} / \mathrm{T}$ & $\mathrm{C} / \mathrm{T}$ & $\mathrm{C} / \mathrm{C}$ & $\mathrm{T} / \mathrm{T}$ & $\mathrm{C} / \mathrm{T}$ & $\mathrm{C} / \mathrm{C}$ & $\mathrm{N}$ \\
\hline \multirow[t]{3}{*}{ TRIM5 } & rs16934386 & $\mathrm{A} / \mathrm{A}$ & $\mathrm{A} / \mathrm{A}$ & $\mathrm{A} / \mathrm{A}$ & $\mathrm{A} / \mathrm{A}$ & $\mathrm{A} / \mathrm{A}$ & $\mathrm{A} / \mathrm{A}$ & $\mathrm{A} / \mathrm{A}$ & $\mathrm{A} / \mathrm{A}$ & $\mathrm{A} / \mathrm{A}$ & $\mathrm{A} / \mathrm{A}$ & $\mathrm{N}$ \\
\hline & rs10838525 & $\mathrm{C} / \mathrm{T}$ & $\mathrm{C} / \mathrm{C}$ & $\mathrm{C} / \mathrm{C}$ & $\mathrm{T} / \mathrm{T}$ & $\mathrm{C} / \mathrm{T}$ & $\mathrm{C} / \mathrm{C}$ & $\mathrm{C} / \mathrm{C}$ & $\mathrm{T} / \mathrm{T}$ & $\mathrm{C} / \mathrm{T}$ & $\mathrm{C} / \mathrm{C}$ & $\mathrm{N}$ \\
\hline & rs3740996 & $\mathrm{G} / \mathrm{G}$ & $\mathrm{G} / \mathrm{G}$ & $\mathrm{G} / \mathrm{G}$ & $\mathrm{G} / \mathrm{G}$ & $\mathrm{G} / \mathrm{G}$ & $\mathrm{G} / \mathrm{G}$ & $\mathrm{G} / \mathrm{G}$ & $\mathrm{G} / \mathrm{G}$ & $\mathrm{A} / \mathrm{G}$ & $\mathrm{G} / \mathrm{G}$ & $\mathrm{N}$ \\
\hline ZNRDI & rs3869068 & $\overline{\mathrm{CT}}$ & $\mathrm{C} / \mathrm{C}$ & $\mathrm{C} / \mathrm{C}$ & $\mathrm{C} / \mathrm{C}$ & $\mathrm{C} / \mathrm{C}$ & $\mathrm{C} / \mathrm{C}$ & $\mathrm{C} / \mathrm{C}$ & $\mathrm{C} / \mathrm{C}$ & $\mathrm{T} / \mathrm{T}$ & $\mathrm{C} / \mathrm{C}$ & $\mathrm{N}$ \\
\hline
\end{tabular}

$\mathrm{O}$ indivíduo $\mathrm{P} 7$, único bom respondedor, carrega em homozigose os polimorfismos de CCL5, rs2280789 e rs2107538, e de CXCL12/SDF1, rs1801157, porém apenas o rs2280789 é exclusivo do P7. A quimiocina CCL5 é considerada um fator de suscetibilidade ao HIV-1, pela ligação competitiva e downregulação de CCR5, ou seja, pode inibir a entrada do vírus e a replicação. O alelo polimórfico T do SNP rs2107538 tem sido reportado como aumentar a transcrição de CCL5, podendo levar a uma alta concentração plasmática (LI; LIU; HONG, 2014). No entanto, o alelo polimórfico G de rs2280789 está relacionado com baixa expressão de CCL5, favorecendo a infecção pelo HIV-1 e a progressão da doença (AN et al., 2002).

Um outro dado que queremos destacar é a heterozigose de P7 pelo SNP de PARD3B rs11884476. Esse dado replica os nossos resultados de genotipagem dos pacientes submetidos à imunoterapia na fase I do ensaio clínico, aonde o mesmo SNP, de acordo com um modelo over-dominante, estava também associado à uma boa resposta ao tratamento (PONTILLO et al., 2014). 

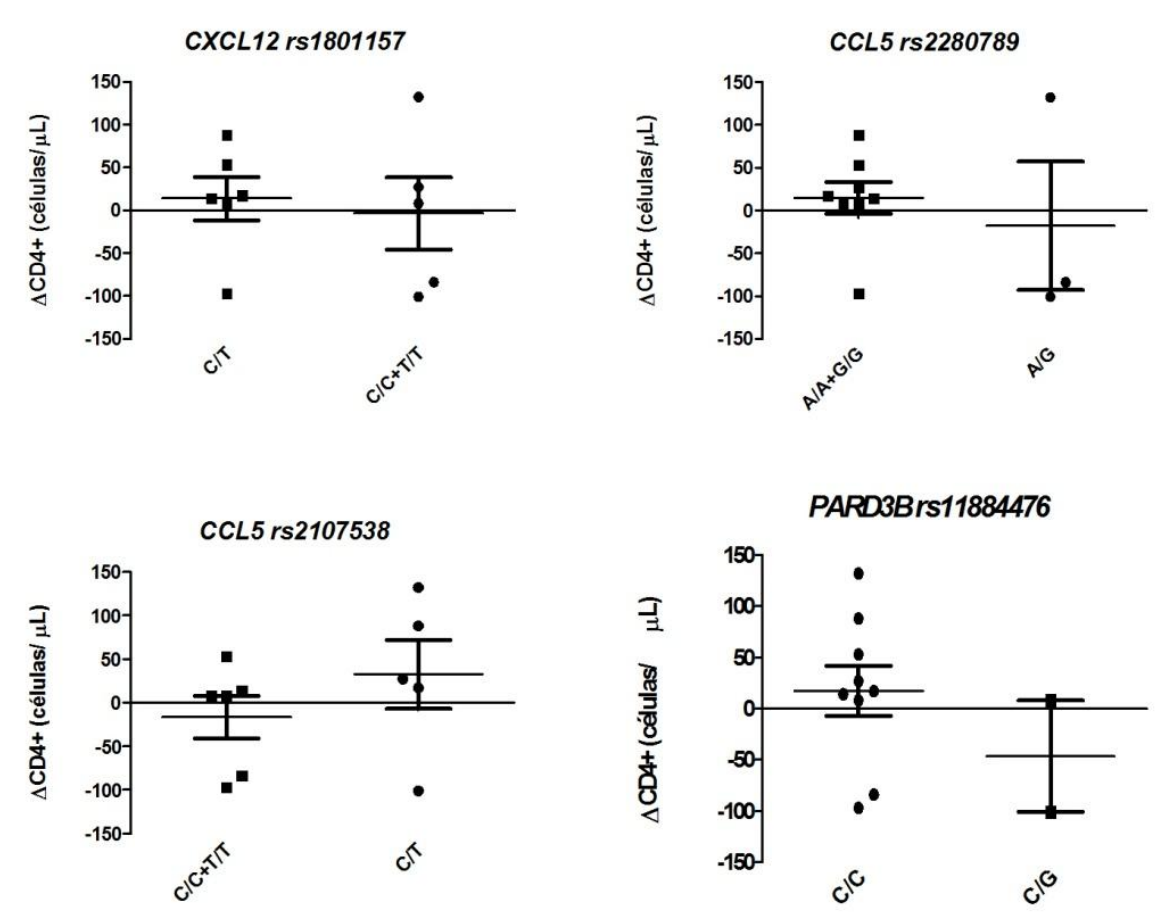

Figura 25 - - Contagem de CD4+ em 11 pacientes em t3 em acordo com os genótipos dos polimorfismos analisados. A análise estatística foi feita no software GraphPad Prism®, mediante $t$ test. ${ }^{*} \mathrm{p}<0,05$.

Quando tentamos associar os dados de genotipagem com a variação de CD4+ (Figura 25) ou a variação de CVP (Figura 26) vimos que não houve nenhuma associação significativa com a variação de carga viral ou CD4+. Os gráficos dos demais polimorfismos não foram mostrados. 

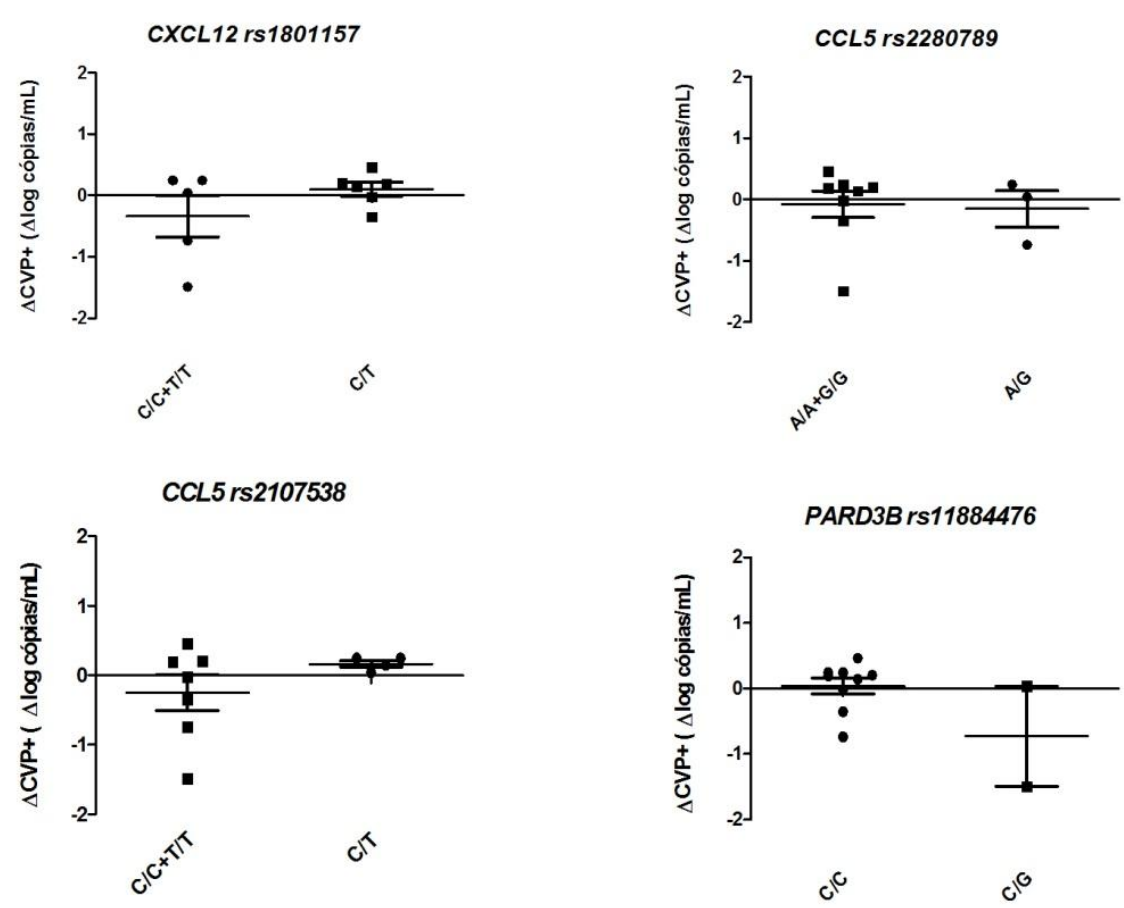

Figura 26 - Redução da carga viral plasmática (CVP) em 11 pacientes em t3 em acordo com os genótipos dos polimorfismos analisados. A análise estatística foi feita no software GraphPad Prism ${ }^{\circledR}$, mediante $t$ test.

\subsection{Discussão: genotipagem dos pacientes submetidos à imunoterapia}

O nosso grupo de pesquisa hipotetizou que o background genético do paciente submetido à imunoterapia pode afetar a resposta ao tratamento.

Os resultados obtidos com relação a genotipagem dos SNPs de MBL2 e NOS1 não foram suficientes para replicar os dados observados no ensaio clínico de fase I desenvolvido na UFPE (SEGAT et al., 2010).

A análise dos polimorfismos nos fatores de restrição mostrou a presença no P7 dos SNPs de CCL5, rs2280789 e rs2107538. No ensaio clínico de fase I, foi visto por Pontillo et al. (2014) que em indivíduos com uma boa resposta estavam presentes os genótipos C/C e A/A para os SNPs de CCL5 rs2107538 e rs2280789, respectivamente, mas é importante considerar que essa associação não foi significativa. $\mathrm{O}$ fato do bom respondedor desse estudo atual ter apresentado genótipos diferentes não permite maiores conclusões, já que antes era analisado um grupo de bons respondedores e agora apenas 1 indivíduo.

Por outro lado, o P7 resultou heterozigose pelo SNP de PARD3B rs11884476. Esse dado replica os nossos resultados de genotipagem dos pacientes submetidos à imunoterapia na 
fase I do ensaio clínico, aonde o mesmo SNP, de acordo com um modelo over-dominante, estava também associado à uma boa resposta ao tratamento (PONTILLO et al., 2014).

Esses dados reforçam a hipótese de que indivíduos com um perfil genético menos permissivo à infecção ou replicação viral poderiam responder melhor à imunoterapia. 


\section{CONCLUSÃO}

No presente estudo avaliamos a contribuição do perfil genético de pacientes HIV+ submetidos à imunoterapia no ensaio de fase I/II tanto como background genético quanto como modulação de expressão gênica nas etapas de diferenciação in vitro de monócitos-DC e em PMBC isolados antes e após o tratamento. Esse estudo pertence a um amplo trabalho que objetivou explorar esse background genético da resposta à imunoterapia e identificar marcadores preditivos de sucesso ao tratamento. $\mathrm{O}$ nosso grupo de pesquisa está convencido de que a resposta à imunoterapia baseada em células dendríticas pode ser considerada com um traço multifatorial, onde fatores genéticos devem ser levados em consideração e que, futuramente, esses marcadores possam ser considerados para outros ensaios clínicos.

Os nossos resultados apontaram que:

- existe diferenças no perfil de expressão de genes envolvidos na resposta a HIV-1 nas DC dos pacientes incluídos no ensaio clínico de modo independente das etapas de diferenciação in vitro de monócitos-DC. Essa diferença observada, aparentemente não correlacionou com características fenotípicas ou funcionais das DC nem com a resposta à imunoterapia já que nenhum dos pacientes analisados respondeu ao tratamento;

- apesar de apenas um indivíduo responder bem à imunoterapia, o P7 mostrou um perfil de expressão gênica específico relacionado com um maior controle de replicação viral e uma resposta polarizada para Th1. Porém não podemos descartar que essa boa resposta à imunoterapia possa ser decorrente de fatores intrínsecos do paciente relacionados com a capacidade dele de controlar a infecção.

-o único paciente que responde à imunoterapia carrega um polimorfismo associado, previamente no ensaio clínico de fase I (UFPE), a uma boa resposta. Isso confirma a hipótese que o background genético possa afetar a resposta ao tratamento de modo semelhante à resposta a infecção por HIV-1/progressão a AIDS.

Desta forma, também considerando que os resultados são limitados pelo número de amostras analisadas, podemos sugerir que a avaliação do perfil genômico deveria ser considerada importante no desenho dos ensaios clínicos. 


\section{REFERÊNCIAS}

AN, P. et al. Modulating influence on HIV/AIDS by interacting RANTES gene variants. Proc. Natl. Acad. Sci. U. S. A., v. 99, n. 15, p. 10002-10007, Jul 232002.

AN, P.; WINKLER, C. A. Host genes associated with HIV/AIDS: advances in gene discovery. Trends Genet., v. 26, n. 3, p. 119-131, Mar 2010.

ARICO, E. et al. Immature monocyte derived dendritic cells gene expression profile in response to Virus-Like Particles stimulation. J. Transl. Med., v. 3, p. 45, 2005.

BAKER, B. M. et al. Elite control of HIV infection: implications for vaccine design. Expert Opin. Biol. Ther., v. 9, n. 1, p. 55-69, Jan 2009.

BANCHEREAU, J.; STEINMAN, R. M. Dendritic cells and the control of immunity. Nature, v. 392, n. 6673, p. 245-252, Mar 191998.

BARRON, M. A. et al. Influence of plasma viremia on defects in number and immunophenotype of blood dendritic cell subsets in human immunodeficiency virus 1infected individuals. J. Infect. Dis., v. 187, n. 1, p. 26-37, Jan 12003.

BONIOTTO, M. et al. MBL2 polymorphisms are involved in HIV-1 infection in Brazilian perinatally infected children. AIDS, v. 17, n. 5, p. 779-80, Mar 282003.

BOSWELL, K. L. et al. Loss of circulating CD4 T cells with B cell helper function during chronic HIV infection. PLoS Pathog., v. 10, n. 1, p. e1003853, Jan 2014.

BRASIL. Ministério da Saúde. Departamento de DST, Aids e Hepatites Virais. AIDS Boletim Epidemiológico: AIDS/DST, 2013.

BRYANT, P. A. et al. Detection of gene expression in an individual cell type within a cell mixture using microarray analysis. PLoS One, v. 4, n. 2, p. e4427, 2009.

BUONAGURO, L. et al. Gene expression profile of peripheral blood mononuclear cells in response to HIV-VLPs stimulation. BMC Bioinformatics, v. 9 Suppl 2, p. S5, 2008.

BUONAGURO, L.; PULENDRAN, B. Immunogenomics and systems biology of vaccines. Immunol. Rev., v. 239, n. 1, p. 197-208, Jan 2011.

CARRINGTON, M.; MARTIN, M. P.; VAN BERGEN, J. KIR-HLA intercourse in HIV disease. Trends Microbiol., v. 16, n. 12, p. 620-627, Dez 2008.

CARRINGTON, M. et al. HLA and HIV-1: heterozygote advantage and B*35-Cw*04 disadvantage. Science, v. 283, n. 5408, p. 1748-1752, Mar 121999.

* De acordo com:

ASSOCIAÇÃO BRASILEIRA DE NORMAS TÉCNICAS. NBR 6023: informação e documentação: referências: elaboração. Rio de Janeiro, 2002. 
CARRINGTON, M.; O'BRIEN, S. J. The influence of HLA genotype on AIDS. Annu. Ver. Med., v. 54, p. 535-551, 2003.

CHATTERJEE, A. et al. Chemokines and chemokine receptors in susceptibility to HIV-1 infection and progression to AIDS. Dis. Markers, v. 32, n. 3, p. 143-151, 2012.

CHEN, L. F.; HOY, J.; LEWIN, S. R. Ten years of highly active antiretroviral therapy for HIV infection. Med. J. Aust., v. 186, n. 3, p. 146-151, Fev 52007.

COCCHI, F. et al. Identification of RANTES, MIP-1 alpha, and MIP-1 beta as the major HIV-suppressive factors produced by CD8+ T cells. Science, v. 270, n. 5243, p. 1811-1815, Dez 151995.

CONNOLLY, N. C. et al. Therapeutic immunization with human immunodeficiency virus type 1 (HIV-1) peptide-loaded dendritic cells is safe and induces immunogenicity in HIV-1infected individuals. Clin. Vaccine Immunol., v. 15, n. 2, p. 284-92, Fev 2008.

DAVEY, R. T., JR. et al. HIV-1 and T cell dynamics after interruption of highly active antiretroviral therapy (HAART) in patients with a history of sustained viral suppression. Proc. Natl. Acad. Sci. U. S. A., v. 96, n. 26, p. 15109-15114, Dez 211999.

DE GOEDE, A. L. et al. DC immunotherapy in HIV-1 infection induces a major blood transcriptome shift. Vaccine, v. 33, n. 25, p. 2922-2929, Jun 92015.

DEAN, M. et al. Genetic restriction of HIV-1 infection and progression to AIDS by a deletion allele of the CKR5 structural gene. Hemophilia Growth and Development Study, Multicenter AIDS Cohort Study, Multicenter Hemophilia Cohort Study, San Francisco City Cohort, ALIVE Study. Science, v. 273, n. 5283, p. 1856-1862, Set 271996.

DOLAN, M. J. et al. CCL3L1 and CCR5 influence cell-mediated immunity and affect HIVAIDS pathogenesis via viral entry-independent mechanisms. Nat. Immunol., v. 8, n. 12, p. 1324-1336, Dec 2007.

FELLAY, J. et al. Host genetic determinants of T cell responses to the MRKAd5 HIV-1 gag/pol/nef vaccine in the step trial. J. Infect. Dis., v. 203, n. 6, p. 773-779, Mar 152011.

FINZI, D.; SILICIANO, R. F. Viral Dynamics in HIV-1 Infection. Cell, v. 93, n. 5, p. 665$671,5 / 29 / 1998$.

FONTAINE, J.; POUDRIER, J.; ROGER, M. Short communication: persistence of high blood levels of the chemokines CCL2, CCL19, and CCL20 during the course of HIV infection. AIDS Res. Hum. Retroviruses, v. 27, n. 6, p. 655-7, Jun 2011.

GANDHI, R. T. et al. A randomized therapeutic vaccine trial of canarypox-HIV-pulsed dendritic cells vs. canarypox-HIV alone in HIV-1-infected patients on antiretroviral therapy. Vaccine, v. 27, n. 43, p. 6088-6094, Out 92009.

GAO, X. et al. Effect of a single amino acid change in MHC class I molecules on the rate of progression to AIDS. N. Eng.l J. Med., v. 344, n. 22, p. 1668-16675, Maio 312001. 
GARCIA, F. et al. A therapeutic dendritic cell-based vaccine for HIV-1 infection. J. Infect. Dis., v. 203, n. 4, p. 473-478, Fev 152011.

GARCIA, F.; ROUTY, J. P. Challenges in dendritic cells-based therapeutic vaccination in HIV-1 infection Workshop in dendritic cell-based vaccine clinical trials in HIV-1. Vaccine, v. 29, n. 38, p. 6454-6463, Set 22011.

GARCIA, F. et al. Immunotherapy and therapeutic vaccines in HIV infection. Enferm. Infecc. Microbiol. Clin., v. 23 Suppl 2, p. 84-104, Jul 2005.

GIRI, M. S. et al. Microarray data on gene modulation by HIV-1 in immune cells: 20002006. J. Leukoc. Biol., v. 80, n. 5, p. 1031-1043, Nov 2006.

GIRI, M. S. et al. Circulating monocytes in HIV-1-infected viremic subjects exhibit an antiapoptosis gene signature and virus- and host-mediated apoptosis resistance. J. Immunol., v. 182, n. 7, p. 4459-4470, Abr 12009.

GONZALEZ, E. et al. Race-specific HIV-1 disease-modifying effects associated with CCR5 haplotypes. Proc. Natl. Acad. Sci. U. S. A., v. 96, n. 21, p. 12004-12009, Out 121999.

GUILLOT-DELOST, M. et al. Human CD90 identifies Th17/Tc17 T cell subsets that are depleted in HIV-infected patients. J. Immunol., v. 188, n. 3, p. 981-991, Fev 12012.

HAGAN, T. et al. Systems vaccinology: Enabling rational vaccine design with systems biological approaches. Vaccine, Apr 62015.

HARALAMBIEVA, I. H. et al. High-dimensional gene expression profiling studies in high and low responders to primary smallpox vaccination. J. Infect. Dis., v. 206, n. 10, p. 15121520, Nov 152012.

HARMAN, A. N. et al. HIV-1-infected dendritic cells show 2 phases of gene expression changes, with lysosomal enzyme activity decreased during the second phase. Blood, v. 114, $\mathrm{n}$. 1, p. 85-94, Jul 22009.

HARMAN, A. N. et al. HIV induces maturation of monocyte-derived dendritic cells and Langerhans cells. J Immunol, v. 177, n. 10, p. 7103-7113, Nov 152006.

HUANG, Q. et al. The plasticity of dendritic cell responses to pathogens and their components. Science, v. 294, n. 5543, p. 870-5, Out 262001.

HÜTTER, G. et al. Long-Term Control of HIV by CCR5 Delta32/Delta32 Stem-Cell Transplantation. New England Journal of Medicine, v. 360, n. 7, p. 692-698, 2009.

HYRCZA, M. D. et al. Distinct transcriptional profiles in ex vivo CD4+ and CD8+ T cells are established early in human immunodeficiency virus type 1 infection and are characterized by a chronic interferon response as well as extensive transcriptional changes in CD8+ T cells. J Virol, v. 81, n. 7, p. 3477-3486, Apr 2007. 
IDE, F. et al. Peptide-loaded dendritic-cell vaccination followed by treatment interruption for chronic HIV-1 infection: a phase 1 trial. J. Med. Virol., v. 78, n. 6, p. 711-718, Jun 2006.

IZMAILOVA, E. et al. HIV-1 Tat reprograms immature dendritic cells to express chemoattractants for activated T cells and macrophages. Nat. Med., v. 9, n. 2, p. 191-197, Fev 2003.

JI, X.; GEWURZ, H.; SPEAR, G. T. Mannose binding lectin (MBL) and HIV. Mol. Immunol., v. 42, n. 2, p. 145-152, Fev 2005.

JURADO, J. O. et al. ICOS, SLAM and PD-1 expression and regulation on T lymphocytes reflect the immune dysregulation in patients with HIV-related illness with pulmonary tuberculosis. J. Int. AIDS So.c, v. 15, n. 2, p. 17428, 2012.

KLOVERPRIS, $\mathrm{H}$. et al. Induction of novel CD8+ T-cell responses during chronic untreated HIV-1 infection by immunization with subdominant cytotoxic T-lymphocyte epitopes. Aids, v. 23, n. 11, p. 1329-1340, Jul 172009.

KORNBLUTH, R. S. The emerging role of CD40 ligand in HIV infection. J. Leukoc. Biol., v. 68, n. 3, p. 373-382, Set 2000.

KRISHNAN, S. et al. Evidence for innate immune system activation in HIV type 1-infected elite controllers. J. Infect. Dis., v. 209, n. 6, p. 931-939, Mar 2014.

KUHL, B. D. et al. Tetherin restricts direct cell-to-cell infection of HIV-1. Retrovirology, v. 7, p. 115, 2010.

KULKARNI, H. et al. Role of CCL3L1-CCR5 genotypes in the epidemic spread of HIV-1 and evaluation of vaccine efficacy. PLoS One, v. 3, n. 11, p. e3671, 2008.

KUNDU, S. K. et al. A pilot clinical trial of HIV antigen-pulsed allogeneic and autologous dendritic cell therapy in HIV-infected patients. AIDS Res. Hum. Retroviruses, v. 14, n. 7, p. 551-60, Maio 11998.

KUPZ, A. et al. NLRC4 inflammasomes in dendritic cells regulate noncognate effector function by memory CD8(+) T cells. Nat. Immuno.l, v. 13, n. 2, p. 162-169, Fev 2012.

LARSSON, M. et al. Molecular signatures of T-cell inhibition in HIV-1 infection. Retrovirology, v. 10, p. 31, 2013.

LI, H.; LIU, T.-J.; HONG, Z.-H. Gene polymorphisms in CCR5, CCR2, SDF1 and RANTES among Chinese Han population with HIV-1 infection. Infection, Genetics and Evolution, v. 24, n. 0, p. 99-104, 6// 2014.

LIU, W. M. et al. The gene expression profile of unstimulated dendritic cells can be used as a predictor of function. Int. J. Cancer, v. 130, n. 4, p. 979-990, Feb 152012.

LOKE, P.; ALLISON, J. P. Emerging mechanisms of immune regulation: the extended B7 family and regulatory T cells. Arthritis Res. Ther., v. 6, n. 5, p. 208-214, 2004. 
LU, W. et al. Therapeutic dendritic-cell vaccine for chronic HIV-1 infection. Nat Med, v. 10, n. 12, p. 1359-1365, Dez 2004.

LU, W. et al. Therapeutic dendritic-cell vaccine for simian AIDS. Nat. Med., v. 9, n. 1, p. 27-32, Jan 2003.

MACKELPRANG, R. D. et al. Maternal HLA homozygosity and mother-child HLA concordance increase the risk of vertical transmission of HIV-1. J. Infect. Dis., v. 197, n. 8, p. 1156-61, Abr 152008.

MANGANO, A. et al. Concordance between the $\mathrm{CC}$ chemokine receptor 5 genetic determinants that alter risks of transmission and disease progression in children exposed perinatally to human immunodeficiency virus. J. Infect. Dis., v. 183, n. 11, p. 1574-1585, Jun 12001.

MARRAS, F. et al. Natural killer cells in HIV controller patients express an activated effector phenotype and do not up-regulate NKp44 on IL-2 stimulation. Proc. Natl. Acad. Sci. U. S. A., v. 110, n. 29, p. 11970-11975, Jul 162013.

MILANESE, M. et al. DEFB1 gene polymorphisms and increased risk of HIV-1 infection in Brazilian children. AIDS, v. 20, n. 12, p. 1673-5, Aug 12006.

MONROE, K. M. et al. IFI16 DNA sensor is required for death of lymphoid CD4 T cells abortively infected with HIV. Science, v. 343, n. 6169, p. 428-432, Jan 242014.

MOURA, R. et al. Exome analysis of HIV patients submitted to dendritic cells therapeutic vaccine reveals an association of CNOT1 gene with response to the treatment. J. Int. AIDS Soc., v. 17, p. 18938, 2014.

MURAKAMI, T.; YAMAMOTO, N. Role of CXCR4 in HIV infection and its potential as a therapeutic target. Future Microbiol., v. 5, n. 7, p. 1025-1039, Jul 2010.

MURATA, H.; HRUZ, P. W.; MUECKLER, M. The mechanism of insulin resistance caused by HIV protease inhibitor therapy. J. Biol. Chem., v. 275, n. 27, p. 20251-20254, Jul 72000.

NAKAYA, H. I.; PULENDRAN, B. Vaccinology in the era of high-throughput biology. Philos. Trans. R. Soc. Lond. B. Biol. Sci., v. 370, n. 1671, Jun 192015.

NISSEN, S. K. et al. Innate DNA sensing is impaired in HIV patients and IFI16 expression correlates with chronic immune activation. Clin. Exp. Immunol., v. 177, n. 1, p. 295-309, Jul 2014.

O'BRIEN, S. J.; NELSON, G. W. Human genes that limit AIDS. Nat. Genet., v. 36, n. 6, p. 565-74, Jun 2004.

O'CONNOR, A. M.; CRAWLEY, A. M.; ANGEL, J. B. Interleukin-7 enhances memory CD8(+) T-cell recall responses in health but its activity is impaired in human immunodeficiency virus infection. Immunology, v. 131, n. 4, p. 525-536, Dez 2010. 
PAULS, E. et al. Restriction of HIV-1 replication in primary macrophages by IL-12 and IL18 through the upregulation of SAMHD1. J. Immunol., v. 190, n. 9, p. 4736-4741, Maio 1 2013.

PENA, J. et al. Lymphocyte activation gene-3 expression defines a discrete subset of HIVspecific CD8 $+\mathrm{T}$ cells that is associated with lower viral load. AIDS Res. Hum. Retroviruses, v. 30, n. 6, p. 535-541, Jun 2014.

PION, M. et al. Phenotype and functional analysis of human monocytes-derived dendritic cells loaded with a carbosilane dendrimer. Biomaterials, v. 31, n. 33, p. 8749-5878, Nov 2010.

PONTILLO, A. et al. A 3'UTR SNP in NLRP3 gene is associated with susceptibility to HIV1 infection. J. Acquir. Immune Defic. Syndr., v. 54, n. 3, p. 236-240, Jul 2010.

PONTILLO, A. et al. Host genomic HIV restriction factors modulate the response to dendritic cell-based treatment against HIV-1. Hum. Vaccin. Immunother., v. 10, n. 2, p. 512-518, Fev 12014.

PONTILLO, A. et al. Polymorphisms in inflammasome' genes and susceptibility to HIV-1 infection. J. Acquir. Immune Defic. Syndr., v. 59, n. 2, p. 121-125, Fev 12012.

PONTILLO, A. et al. HIV-1 induces NALP3-inflammasome expression and interleukin1 beta secretion in dendritic cells from healthy individuals but not from HIV-positive patients. AIDS, v. 26, n. 1, p. 11-18, Jan 22012.

POONIA, B.; PAUZA, C. D. Levels of CD56+TIM-3- effector CD8 T cells distinguish HIV natural virus suppressors from patients receiving antiretroviral therapy. PLoS One, v. 9, n. 2, p. e88884, 2014.

RAMIREZ, P. W. et al. Downmodulation of CCR7 by HIV-1 Vpu results in impaired migration and chemotactic signaling within CD4(+) T cells. Cell Rep., v. 7, n. 6, p. 20192030, Jun 262014.

RAPOSO, R. A. et al. Effects of cellular activation on anti-HIV-1 restriction factor expression profile in primary cells. J. Virol., v. 87, n. 21, p. 11924-11929, Nov 2013.

READ, S. W. et al. Decreased CD127 expression on T Cells in HIV-1-infected adults receiving antiretroviral therapy with or without intermittent IL-2 therapy. J. Acquir. Immune Defic. Syndr., v. 42, n. 5, p. 537-544, Ago 152006.

RIBEIRO-DOS-SANTOS, P. et al. Chronic HIV infection affects the expression of the 2 transcription factors required for CD8 T-cell differentiation into cytolytic effectors. Blood, $\mathrm{v}$. 119, n. 21, p. 4928-38, Maio 242012.

RODRIGUEZ-GALAN, M. C. et al. Coexpression of IL-18 strongly attenuates IL-12induced systemic toxicity through a rapid induction of IL-10 without affecting its antitumor capacity. .J Immunol., v. 183, n. 1, p. 740-748, Jul 12009. 
RODRIGUEZ, A. R. et al. T cell interleukin-15 surface expression in chimpanzees infected with human immunodeficiency virus. Cell Immunol., v. 288, n. 1-2, p. 24-30, Mar-Abr 2014.

ROSSIO, J. L. et al. Inactivation of human immunodeficiency virus type 1 infectivity with preservation of conformational and functional integrity of virion surface proteins. J. Virol., v. 72, n. 10, p. 7992-8001, Out 1998.

ROTGER, M. et al. Genome-wide mRNA expression correlates of viral control in CD4+ Tcells from HIV-1-infected individuals. PLoS Pathog., v. 6, n. 2, p. e1000781, Fev 2010.

ROUTY, J. P. et al. Immunologic activity and safety of autologous HIV RNA-electroporated dendritic cells in HIV-1 infected patients receiving antiretroviral therapy. Clin. Immunol., v. 134, n. 2, p. 140-147, Fev 2010.

SAMSON, M. et al. Resistance to HIV-1 infection in caucasian individuals bearing mutant alleles of the CCR-5 chemokine receptor gene. Nature, v. 382, n. 6593, p. 722-7225, Ago 22 1996.

SCHERER, C. A. et al. Distinct gene expression profiles in peripheral blood mononuclear cells from patients infected with vaccinia virus, yellow fever 17D virus, or upper respiratory infections. Vaccine, v. 25, n. 35, p. 6458-6473, Ago 292007.

SCHMITTGEN, T. D.; LIVAK, K. J. Analyzing real-time PCR data by the comparative C(T) method. Nat. Protoc., v. 3, n. 6, p. 1101-1108, 2008.

SEGAT, L. et al. Polymorphisms in innate immunity genes and patients response to dendritic cell-based HIV immuno-treatment. Vaccine, v. 28, n. 10, p. 2201-2206, Mar 22010.

SENNEPIN, A. et al. NKp44L expression on CD4+ $\mathrm{T}$ cells is associated with impaired immunological recovery in HIV-infected patients under highly active antiretroviral therapy. AIDS, v. 27, n. 12, p. 1857-1866, Jul 312013.

SOGHOIAN, D. Z. et al. HIV-specific cytolytic CD4 T cell responses during acute HIV infection predict disease outcome. Sci. Transl. Med., v. 4, n. 123, p. 123ra25, Feb 292012.

TANASKOVIC, S. et al. Interleukin-7 signalling defects in naive CD4+ T cells of HIV patients with CD4+ T-cell deficiency on antiretroviral therapy are associated with T-cell activation and senescence. AIDS, v. 28, n. 6, p. 8218-30, Mar 272014.

TANG, J. et al. Human leukocyte antigen class I genotypes in relation to heterosexual HIV type 1 transmission within discordant couples. J. Immuno.l, v. 181, n. 4, p. 2626-2635, Ago 152008 .

TORRI, A. et al. Gene expression profiles identify inflammatory signatures in dendritic cells. PLoS One, v. 5, n. 2, p. e9404, 2010.

TUANA, G. et al. Classification of dendritic cell phenotypes from gene expression data. BMC Immunol., v. 12, p. 50, 2011. 
VAN VAERENBERGH, K. Study of the impact of HIV genotypic drug resistance testing on therapy efficacy. Verh. K. Acad. Geneeskd. Belg., v. 63, n. 5, p. 447-473, 2001.

VETTER, M. L. et al. Differences in APOBEC3G expression in CD4+ T helper lymphocyte subtypes modulate HIV-1 infectivity. PLoS Pathog., v. 5, n. 2, p. e1000292, Fev 2009.

WHITTALL, T. et al. Immunogenic and tolerogenic signatures in human immunodeficiency virus (HIV)-infected controllers compared with progressors and a conversion strategy of virus control. Clin. Exp. Immunol., v. 166, n. 2, p. 208-217, Nov 2011.

WINKLER, C. et al. Genetic restriction of AIDS pathogenesis by an SDF-1 chemokine gene variant. ALIVE Study, Hemophilia Growth and Development Study (HGDS), Multicenter AIDS Cohort Study (MACS), Multicenter Hemophilia Cohort Study (MHCS), San Francisco City Cohort (SFCC). Science, v. 279, n. 5349, p. 389-593, Jan 161998.

WOLF, B. et al. Gene expression profile of peripheral blood lymphocytes from renal cell carcinoma patients treated with IL-2, interferon-alpha and dendritic cell vaccine. PLoS One, v. 7, n. 12, p. e50221, 2012.

WONG, J. L. et al. IL-18-primed helper NK cells collaborate with dendritic cells to promote recruitment of effector $\mathrm{CD} 8+\mathrm{T}$ cells to the tumor microenvironment. Cancer Res., v. 73, $\mathrm{n}$. 15, p. 4653-4662, Ago 12013.

YAMAMOTO, T. et al. Surface expression patterns of negative regulatory molecules identify determinants of virus-specific CD8+ T-cell exhaustion in HIV infection. Blood, v. 117, n. 18, p. 4805-4815, Maio 52011.

YOUNAI, F. S. Thirty years of the human immunodeficiency virus epidemic and beyond. Int. J. Oral. Sci., v. 5, n. 4, p. 191-199, Dez 2013.

ZHANG, Z.-N. et al. Elevation of Tim-3 and PD-1 Expression on T Cells Appears Early in HIV Infection, and Differential Tim-3 and PD-1 Expression Patterns Can Be Induced by Common \&\#x3b3;-Chain Cytokines. BioMed. Research International, v. 2015, p. 11, 2015. 


\section{APÊNDICE A - Perfil de expressão durante etapas de diferenciação de DC= P1-P6 (FC)}

\begin{tabular}{|c|c|c|c|c|c|c|c|c|c|c|c|c|}
\hline row.names & P1_iDC & P2_iDC & P4_iDC & P3_iDC & P5_idC & P6_idC & P1_4h & P2_4h & P4_4h & P3_4h & P5_4h & P6_4h \\
\hline APEX1 & $-2,62$ & 3,54 & 5,12 & 1,86 & $-2,94$ & $-0,04$ & $-2,08$ & 3,48 & 4,92 & 1,57 & $-3,34$ & $-1,82$ \\
\hline APOBEC3G & 0 & 3,77 & 4,61 & 0,95 & 0,59 & 0 & 0 & 3,63 & 4,21 & $-0,37$ & 0,38 & 0 \\
\hline BAD & $-17,57$ & 5,28 & 5,78 & 1,79 & -4 & $-15,78$ & $-16,13$ & 5,06 & 5,53 & 1,6 & $-4,09$ & $-15,71$ \\
\hline BANF1 & 0 & 3,63 & 4,3 & 0,48 & 0,43 & 0 & 0 & 3,58 & 4,32 & 0,62 & 0,43 & 0 \\
\hline BAX & $-2,39$ & $-2,94$ & 4,62 & 1,92 & $-4,14$ & $-4,86$ & $-1,41$ & $-7,28$ & 4,57 & 1,98 & $-4,48$ & $-4,67$ \\
\hline BCL2 & 1,49 & $-0,17$ & 3,88 & 0,97 & $-2,58$ & 8,26 & 2,67 & $-0,39$ & 3,65 & 0,99 & $-2,36$ & 8,28 \\
\hline CASP3 & 0 & 0,98 & 2,23 & 1,43 & $-1,65$ & 0 & 0 & 0,99 & 2,15 & 1,3 & $-1,57$ & 0 \\
\hline CASP8 & $-5,95$ & 2,56 & 2,75 & 1,42 & $-0,51$ & 0 & $-3,8$ & 2,73 & 2,52 & 1,57 & $-0,53$ & 0 \\
\hline CBX5 & 0 & $-0,31$ & 3,47 & 1,71 & $-1,41$ & 0 & 0 & 0,66 & 3,29 & 1,03 & $-1,46$ & 0 \\
\hline $\mathrm{CCL} 2$ & $-9,33$ & 4,25 & $-0,87$ & $-1,67$ & $-5,85$ & $-10,17$ & $-6,27$ & 4,1 & 3,08 & 0,08 & $-4,27$ & $-7,33$ \\
\hline CCL3 & 0 & 0 & 4,67 & 2,32 & $-0,34$ & 0 & 0 & 0 & 5,44 & 2,75 & 0,2 & 0 \\
\hline CCL4 & $-4,37$ & 0,26 & 5,71 & 2,17 & $-4,8$ & $-3,4$ & 0,19 & 0,19 & 0 & 2,61 & $-3,93$ & $-0,2$ \\
\hline CCL5 & $-6,96$ & 0,88 & 4,69 & 0,67 & $-2,91$ & $-10,72$ & $-8,27$ & $-2,58$ & 4,7 & 0,24 & $-3,3$ & $-7,77$ \\
\hline CCL8 & $-5,68$ & $-2,26$ & $-9,06$ & $-12,02$ & $-12,66$ & 0 & $-1,53$ & $-0,25$ & $-13,72$ & $-11,57$ & $-12,69$ & 0 \\
\hline CCNT1 & $-3,63$ & 1,25 & 4,26 & 0,43 & $-3,33$ & 6,58 & $-2,42$ & 1,24 & 4,16 & $-0,22$ & $-3,31$ & 4,79 \\
\hline CCR2 & 0 & 4,54 & 2,9 & $-2,47$ & $-5,53$ & 0 & 0 & 3,21 & $-0,07$ & $-4,13$ & $-6,79$ & 0 \\
\hline CCR3 & 0 & 5,47 & $-1,16$ & $-6,41$ & $-6,74$ & 0 & 0 & 3,97 & $-2,43$ & $-8,14$ & $-6,64$ & 0 \\
\hline CCR4 & $-1,6$ & 0,4 & $-4,82$ & $-7,69$ & $-8,09$ & 0 & 1,52 & $-1,96$ & $-3,51$ & $-8,47$ & $-7,27$ & 0 \\
\hline CCR5 & 2,39 & 0,62 & 0,67 & 0,28 & $-1,15$ & 0 & 2,58 & 0,52 & 0,69 & 0,53 & $-1,28$ & 0 \\
\hline CD209 & $-0,19$ & 0 & $-0,78$ & 1,74 & $-2,82$ & $-0,17$ & 0,67 & 0 & $-0,78$ & 1,93 & $-2,46$ & 0,8 \\
\hline CD4 & $-1,22$ & 3,48 & 3,02 & 0,24 & $-0,25$ & 0 & 0,59 & 3,35 & 3,09 & $-0,1$ & $-0,32$ & 0 \\
\hline CD44 & $-1,34$ & 0,43 & 3,7 & 2,43 & $-2,8$ & $-3,84$ & $-0,67$ & 0,42 & 3,6 & 2,55 & $-3,14$ & $-3,2$ \\
\hline CD74 & $-4,67$ & 0,84 & 4,84 & $-0,24$ & 2,63 & $-1,11$ & $-3,7$ & 0,73 & 4,64 & $-0,13$ & 2,5 & $-0,72$ \\
\hline CDK7 & $-4,49$ & 2,79 & 4,22 & 0,47 & $-5,31$ & $-1,81$ & $-4,04$ & 2,46 & 4,09 & 0,47 & $-5,27$ & $-0,94$ \\
\hline CDK9 & $-2,94$ & 1,62 & 0,73 & 2 & $-2,42$ & 6,13 & $-1,98$ & 1,73 & 0,54 & 0,26 & $-2,68$ & 1,64 \\
\hline CDKN1A & 0,83 & 0,81 & $-1,5$ & $-1,68$ & $-4,44$ & $-4,01$ & 1,68 & 0,81 & $-1,18$ & $-1,45$ & $-4,1$ & $-2,41$ \\
\hline CEBPB & $-5,15$ & 0,48 & 0,93 & 2,04 & $-3,32$ & $-2,74$ & $-3,18$ & 0,53 & 0,94 & 2,08 & $-3,53$ & $-3,99$ \\
\hline COPS6 & $-4,06$ & 3,33 & 1,91 & 1,34 & $-4,82$ & $-2,67$ & $-3,57$ & 3,19 & 1,88 & 1,37 & $-5,03$ & $-2,7$ \\
\hline CR2 & $-7,45$ & 2,25 & 1,48 & $-2,87$ & $-5,81$ & $-0,04$ & $-5,94$ & 1,94 & 1,24 & $-3,06$ & $-5,61$ & 0,03 \\
\hline CREBBP & $-3,01$ & 1,23 & 2,81 & 0,74 & $-1,1$ & 0 & $-3,49$ & 1,2 & 2,61 & $-0,09$ & $-1,07$ & 0 \\
\hline CX3CL1 & 0 & 10,12 & $-0,73$ & $-4,04$ & $-1,73$ & 0 & 0 & 9,87 & $-0,63$ & $-5,53$ & $-2,26$ & 0 \\
\hline CXCL12 & $-14,3$ & 4,32 & 0 & 0 & 0 & $-11,64$ & $-14,8$ & 0 & $-13,66$ & $-20,81$ & $-14,36$ & $-2,38$ \\
\hline CXCR4 & $-4,22$ & $-1,35$ & 4,61 & 1,41 & $-2,69$ & 5,35 & $-4,1$ & $-1,85$ & 4,04 & $-0,16$ & $-3,61$ & 2,62 \\
\hline ELANE & $-7,23$ & 3,06 & $-4,65$ & $-10,73$ & $-9,19$ & $-4,08$ & $-7,36$ & 3,6 & $-4,77$ & $-11,68$ & $-9,59$ & $-8,43$ \\
\hline EP300 & $-5,4$ & 1,31 & 5,21 & 1,54 & $-4,88$ & $-3,07$ & $-4,33$ & 1,34 & 5,12 & 1,42 & $-4,73$ & $-3,05$ \\
\hline FCAR & 0 & $-8,19$ & $-7,68$ & $-14,04$ & $-16,7$ & 0 & 0 & $-8,81$ & $-5,32$ & $-13,77$ & $-13,87$ & 0 \\
\hline FOS & $-5,55$ & 0,98 & 2,53 & 1,36 & $-5,69$ & $-6,45$ & $-4,65$ & 0,79 & 2,31 & 1,33 & $-6,42$ & $-5,35$ \\
\hline GADD45A & $-3,85$ & 4,44 & 2,79 & 1,23 & $-2,77$ & 2,85 & $-1,61$ & 4,56 & 3,89 & $-0,21$ & -2 & 0,14 \\
\hline $\mathrm{HCK}$ & $-3,44$ & 3,27 & 3,01 & 2,51 & $-3,14$ & 1,7 & $-3,56$ & 3,18 & 2,87 & 1,61 & $-3,66$ & $-1,47$ \\
\hline HMGA1 & $-6,25$ & 1,85 & 1,01 & $-4,14$ & $-6,28$ & 1,96 & $-4,1$ & 1,3 & 0,7 & $-5,55$ & $-6,27$ & 0,19 \\
\hline HTATSF1 & $-4,4$ & 3,4 & 2,62 & 2,67 & $-5,04$ & $-3,4$ & $-3,68$ & 3,45 & 2,54 & 2,82 & $-5,03$ & $-2,89$ \\
\hline IFNA1 & 0 & $-0,11$ & $-3,58$ & $-8,01$ & $-10,93$ & 0 & 0 & $-0,5$ & $-3,74$ & $-7,87$ & $-11,46$ & 0 \\
\hline IFNB1 & 0 & 1,36 & $-3,1$ & $-9,68$ & $-9,29$ & 0 & 0 & 0,12 & $-3,99$ & $-9,78$ & $-9,18$ & 0 \\
\hline IL10 & $-5,78$ & 2,29 & 2,94 & $-1,12$ & $-2,28$ & $-6,17$ & $-3,7$ & 2,36 & 3,55 & $-1,05$ & $-1,93$ & $-5,46$ \\
\hline IL12B & $-1,98$ & $-0,69$ & $-3,69$ & $-8,15$ & $-4,53$ & 4,87 & $-3,07$ & $-1,26$ & $-6,68$ & $-10,75$ & $-6,52$ & $-0,92$ \\
\hline IL16 & $-6,89$ & 1,33 & 4,05 & 0,26 & $-5,16$ & $-1,38$ & $-5,14$ & 1,14 & 4,18 & $-0,26$ & $-5,15$ & $-2,54$ \\
\hline IL1B & $-10,18$ & $-5,3$ & 0,58 & $-3,11$ & $-7,58$ & 0 & $-7,34$ & $-7,18$ & 2,58 & $-3,27$ & $-7,35$ & 0 \\
\hline IL8 & $-10,41$ & $-3,84$ & 1,91 & $-2,5$ & $-10,3$ & $-7,57$ & $-7,09$ & $-5,94$ & 4,02 & $-1,8$ & $-9,47$ & $-4,91$ \\
\hline IRF1 & $-10,7$ & $-0,06$ & 2,82 & 0,59 & $-2,41$ & $-8,08$ & $-7,25$ & 1,47 & 2,92 & 1,27 & $-1,71$ & $-7,32$ \\
\hline IRF2 & $-4,52$ & 0,67 & 1,82 & 1,2 & $-6,12$ & $-5,7$ & $-3,77$ & 0,57 & 1,75 & 1,33 & $-6,19$ & $-5,14$ \\
\hline LTBR & $-4,41$ & 2,94 & 0,44 & 1,54 & $-0,03$ & $-3,26$ & $-4,23$ & 2,93 & 0,33 & 1,65 & $-0,32$ & $-2,57$ \\
\hline MAP3K5 & $-2,72$ & 4,02 & 2,13 & 1,38 & $-4,13$ & 0,14 & $-1,88$ & 3,95 & 1,95 & 0,93 & $-4,39$ & $-1,19$ \\
\hline MBL2 & $-2,67$ & $-0,75$ & $-6,74$ & $-13,23$ & $-10,64$ & $-6,07$ & $-1,65$ & $-0,03$ & $-5,83$ & $-17,18$ & $-12,57$ & $-5,23$ \\
\hline NFKBIA & $-5,49$ & 0,21 & 4,48 & 1,43 & 1,07 & 0,77 & $-4,77$ & $-0,03$ & 4,52 & 1,3 & 0,61 & 1,63 \\
\hline PPIA & 0 & 3,17 & 5,15 & 1,2 & $-1,72$ & 0 & 0 & 2,95 & 5,12 & 0,98 & $-1,58$ & 0 \\
\hline PRDX1 & $-2,2$ & 2,95 & 4,16 & 1,27 & $-3,61$ & 6,3 & $-1,82$ & 2,98 & 3,92 & 0,41 & $-3,48$ & 5,49 \\
\hline PTK2B & $-5,77$ & 1,78 & 4,16 & 1,8 & $-4,28$ & 0,91 & $-5,74$ & 1,59 & 3,68 & 1,36 & $-4,6$ & $-0,68$ \\
\hline RBL2 & 0 & 2,91 & 2,33 & 1,69 & $-1,75$ & 0 & 0 & 2,56 & 2,24 & 1,73 & $-1,94$ & 0 \\
\hline SELL & $-5,61$ & 1,03 & 1,15 & $-1,79$ & $-3,64$ & 0 & $-5,84$ & $-1,31$ & $-0,72$ & $-4,17$ & $-4,4$ & 0 \\
\hline SERPINA1 & $-2,71$ & $-0,02$ & 0,99 & $-1,7$ & $-8,06$ & $-6,09$ & $-2,71$ & $-1,01$ & 0,79 & $-1,59$ & $-8,64$ & $-5,79$ \\
\hline SERPINC1 & 1,29 & 2,2 & $-2,38$ & $-5,57$ & $-6,27$ & 4,12 & 1,18 & 2,6 & $-4,21$ & $-7,51$ & $-6,05$ & $-0,01$ \\
\hline SLPI & $-12,3$ & $-2,85$ & $-6,19$ & $-10,35$ & $-14,16$ & $-4,79$ & $-11,88$ & $-3,55$ & $-6,22$ & $-10,7$ & $-12,8$ & $-3,56$ \\
\hline SMARCB1 & $-5,67$ & 3,26 & 2,05 & 1,68 & $-5,89$ & $-5,71$ & $-4,41$ & 3,04 & 2,01 & 1,82 & $-6,13$ & $-5,25$ \\
\hline STAT1 & $-7,9$ & 1,38 & 1,17 & 2,02 & 0,51 & 3,04 & $-5,22$ & 1,72 & 1,09 & 2,27 & 0,61 & 4,6 \\
\hline STAT3 & $-2,47$ & 0,86 & 5,41 & 1,54 & 0,12 & 0 & $-2,05$ & 1,06 & 5,3 & 1,14 & $-0,16$ & 0 \\
\hline TFCP2 & $-4,87$ & 3,68 & 4,43 & 1,33 & $-5,72$ & $-3,78$ & $-4,36$ & 3,37 & 4,27 & 1,44 & $-5,73$ & $-3,22$ \\
\hline TGFB1 & $-3,27$ & 0,71 & 3,2 & 1,88 & $-3,48$ & $-4,7$ & $-1,8$ & 0,79 & 3,25 & 2,03 & $-3,58$ & $-4,42$ \\
\hline TNF & $-8,54$ & $-0,74$ & 3,51 & $-1,51$ & $-5,84$ & $-11,4$ & $-7,39$ & $-0,98$ & 3,67 & $-1,78$ & $-5,8$ & $-9,5$ \\
\hline TNFRSF1B & $-7,96$ & 0,43 & 0,37 & 1,68 & $-6,09$ & $-7,35$ & $-5,63$ & 0,39 & 0,46 & 1,56 & $-5,88$ & $-8,92$ \\
\hline TNFSF10 & $-9,54$ & $-0,5$ & 2,76 & $-2,54$ & $-5,72$ & 0 & $-9,25$ & $-0,74$ & 0,6 & $-3,42$ & $-6,35$ & 0 \\
\hline TRIM5 & $-6,32$ & 2,62 & 3,36 & 0,07 & $-5,83$ & $-3,21$ & $-5,04$ & 2,49 & 3,31 & 0,01 & $-6,18$ & $-3,02$ \\
\hline TSG101 & $-2,94$ & 2,66 & 1,63 & 1,18 & $-6,18$ & $-5,74$ & -3 & 2,36 & 1,58 & 1,31 & $-6,16$ & $-4,58$ \\
\hline VPS4A & $-5,24$ & 2,75 & 1,75 & 1,94 & $-4,96$ & $-3,19$ & $-3,86$ & 2,69 & 1,76 & 2,05 & $-5,15$ & $-2,49$ \\
\hline XPO1 & $-2,99$ & 2,46 & 0,45 & 1,54 & $-4,96$ & $-3,24$ & $-2,09$ & 2,34 & 0,49 & 1,71 & $-4,99$ & $-2,17$ \\
\hline YY1 & $-2,91$ & 2,04 & 1,14 & 2,07 & $-0,98$ & 0 & $-3,19$ & 2,09 & 0,95 & 2,12 & $-1,18$ & 0 \\
\hline
\end{tabular}




\begin{tabular}{|c|c|c|c|c|c|c|c|c|c|c|c|c|c|c|c|c|c|c|}
\hline \multicolumn{19}{|l|}{ w.names } \\
\hline APEX1 & 1_14h & P2_14h & P4_14h & P3_14h & P5_14h & P6_14h & P1_24h & P2_24h & P4_24h & P3_24h & P5_24h & P6_24h & P1_48h & P2_48h & P4_48h & P3_48h & P5_48h & P6_48h \\
\hline APOBEC3G & $-3,24$ & 3,21 & 5,06 & 1,96 & $-3,53$ & $-1,4$ & $-3,33$ & 2,85 & 4,79 & 1,84 & $-3,84$ & $-1,41$ & $-0,93$ & 7,87 & 6,54 & 1,7 & $-4,28$ & $-5,65$ \\
\hline BAD & 0 & 3,65 & 4,18 & $-0,74$ & 0,4 & 0 & 0 & 3,52 & 4,68 & 1,39 & 1,08 & 10,46 & 10,95 & 6,24 & 6,49 & 1,31 & 1,32 & 9,66 \\
\hline BANF1 & -16 & 4,89 & 5,48 & 1,65 & $-3,75$ & $-15,22$ & $-16,33$ & 4,72 & 5,86 & 1,8 & $-4,12$ & $-15,45$ & $-15,41$ & 2,92 & 3,03 & 26 & $-3,74$ & $-13,78$ \\
\hline BAX & 0 & 3,42 & 4,3 & 0,75 & 0,42 & 0 & 0 & 3,23 & 4,22 & 0,36 & $-0,05$ & 0 & 12,83 & 8,3 & 5,86 & 0,5 & $-0,78$ & 0 \\
\hline $\mathrm{BCL2}$ & $-3,72$ & $-4,4$ & 4,57 & 2,2 & $-4,13$ & $-6,26$ & $-1,51$ & $-3,36$ & 4,57 & 1,85 & $-4,09$ & $-5,96$ & $-0,44$ & 7,67 & 7,1 & 2,11 & $-4,34$ & $-11,23$ \\
\hline CASP3 & 3,24 & $-0,02$ & 3,43 & 0,35 & $-2,16$ & 8,19 & 3,12 & $-0,09$ & 3,76 & 1 & $-2,76$ & 7,92 & 4,05 & 5,72 & 5,58 & 1,43 & $-2,69$ & 6,32 \\
\hline CASP8 & 0 & 0,47 & 2,25 & 0,81 & $-1,76$ & 0 & 0 & 0,51 & 2,19 & 1,47 & $-1,53$ & 0 & 0 & 0,23 & $-0,93$ & 1,7 & $-1,65$ & 0 \\
\hline CBX5 & $-4,99$ & 3,02 & 2,09 & 0,46 & $-0,58$ & 0 & $-6,84$ & 3,32 & 2,48 & 1,24 & $-0,93$ & 0 & $-7,65$ & 7,14 & $-5,46$ & 1,38 & $-1,61$ & 0 \\
\hline CCL2 & 0 & $-0,12$ & 3,82 & 1,44 & $-1,84$ & 0 & 0 & $-2,51$ & 3,44 & 2,92 & $-1,49$ & 0 & 0 & 8,96 & 5,31 & 2,36 & $-1,18$ & 0 \\
\hline CCL3 & $-5,66$ & 4,28 & 0,84 & 0,34 & $-6,58$ & $-7,99$ & $-9,72$ & 3,82 & $-1,95$ & $-3,58$ & $-9,13$ & $-8,27$ & $-10,69$ & $-3,81$ & $-3,03$ & $-6,36$ & $-10,36$ & $-8,34$ \\
\hline CCL4 & 0 & 0 & 5,55 & 3,01 & 2,04 & 0 & 0 & 0 & 5,35 & 2,66 & 1,09 & 0 & 0 & 3,34 & 8,16 & 2,43 & 0,85 & 0 \\
\hline CCL5 & $-3,92$ & 0,2 & 0 & 2,85 & $-2,93$ & $-0,33$ & $-0,8$ & $-0,68$ & 6,18 & 2,44 & $-4,87$ & $-2,5$ & $-1,47$ & 5,42 & 7,5 & 1,07 & $-6,04$ & $-7,8$ \\
\hline CCL8 & $-3,17$ & 1,1 & 5,62 & 0,59 & $-1,16$ & $-3,9$ & $-4,34$ & 1,38 & 5,31 & 1,57 & $-0,66$ & $-5,02$ & $-2,01$ & $-1,79$ & 0,72 & 0,26 & $-1,19$ & $-6,88$ \\
\hline CCNT1 & 0,22 & $-0,4$ & $-8,29$ & $-9,75$ & $-12,87$ & 0 & $-3,47$ & 0,76 & $-8,02$ & $-14,27$ & $-10,97$ & 0 & $-3,68$ & 3,38 & $-7,33$ & $-10,66$ & -11 & 0 \\
\hline CCR2 & $-2,25$ & 1,17 & 4,03 & $-0,88$ & $-3,81$ & 5,5 & $-3,63$ & 1,24 & 3,81 & 0,44 & $-3,84$ & 5,76 & $-0,98$ & 5,99 & 5,17 & $-0,17$ & $-4,21$ & 3,38 \\
\hline CCR3 & 0 & 0,63 & $-2,32$ & $-5,31$ & $-7,24$ & 0 & 0 & 1,65 & $-0,5$ & $-4,22$ & $-6,51$ & 0 & 0 & $-0,57$ & $-2,07$ & $-5,09$ & $-7,46$ & 0 \\
\hline CCR4 & 0 & 3,77 & $-3,26$ & $-8,21$ & $-8,88$ & 0 & 0 & 4,79 & $-2,12$ & $-6,48$ & $-7,28$ & 0 & 0 & 3,24 & $-4,65$ & $-7,24$ & $-4,89$ & 0 \\
\hline CCR5 & 2,98 & 0,01 & $-2,73$ & $-7,66$ & $-7,12$ & 0 & 3,01 & 1,63 & $-2,54$ & $-5,1$ & $-6,3$ & 0 & 5,99 & 5,79 & 1,55 & $-5,85$ & $-3,13$ & 0 \\
\hline CD209 & 0,94 & $-0,43$ & 0,09 & $-0,37$ & $-1,42$ & 0 & 0,07 &, 4 & 44 & $-0,13$ & $-1,93$ & 0 & $-1,51$ & $-2,33$ & $-5,02$ & $-0,6$ & $-3,19$ & 0 \\
\hline $\mathrm{CD} 4$ & $-3,49$ & 0 & $-0,95$ & 2,04 & $-2,49$ & $-1,15$ & $-0,96$ & 0 & $-1,26$ & 1,5 & $-3,2$ & $-1,65$ & $-1,11$ & 15,15 & 0,19 & 0,94 & $-5,3$ & $-6,71$ \\
\hline CD44 & $-1,28$ & 2,59 & 2,47 & $-0,35$ & $-0,68$ & 0 & $-2,27$ & 2,08 & 2,3 & $-0,34$ & $-2,19$ & 0 & $-3,62$ & $-1,29$ & $-6,17$ & $-1,96$ & $-3,78$ & 0 \\
\hline CD74 & $-4,26$ & 0,59 & 3,69 & 2,72 & $-2,68$ & $-3,81$ & $-0,23$ & 0,32 & 3,77 & 2,53 & $-2,83$ & $-3,99$ & 1,33 & 6,98 & 93 & 4 & 19 & $-11,67$ \\
\hline CDK7 & $-3,95$ & 0,76 & 4,53 & 0,02 & 3,08 & $-1,5$ & $-4,68$ & 0,47 & 11 & $-0,08$ & 2,56 & $-1,58$ & $-3, / 5$ & 1,31 & 5,85 & $-0,72$ &, 55 & $-2,53$ \\
\hline CDK9 & $-4,68$ & 2,78 & 3,94 & $-0,27$ & $-5,06$ & $-1,99$ & $-4,16$ & 2,79 & 4,25 & 0,73 & $-4,81$ & $-2,49$ & $-3,01$ & 8,37 & 5,96 & 0,61 & $-4,69$ & $-5,06$ \\
\hline CDKN1A & $-1,69$ & 1,57 & 1,04 & 1,51 & $-3,69$ & 5,36 & $-4,06$ & 1,66 & 0,28 & 2,16 & $-3,84$ & 6,32 & 1,48 & 6,28 & 2,86 & 2,17 & $-2,66$ & 1,95 \\
\hline CEBPB & $-3,82$ & 0,95 & $-1,37$ & $-1,46$ & $-3,32$ & $-3,42$ & 1,57 & 0,77 & $-1,1$ & $-1,2$ & $-3,06$ & $-3,62$ & 2,72 & 8,38 & 98 & $-1,22$ & $-2,82$ & $-12,3$ \\
\hline COPS6 & $-4,75$ & 0,47 & 1,06 & 2,5 & $-3,22$ & $-3,7$ & $-2,63$ & 0,11 & 0,95 & 2,03 & $-3,52$ & $-2,64$ & 0,15 & 5,54 & 3,52 & 2,15 & $-4,6$ & $-9,56$ \\
\hline CR2 & $-4,25$ & 2,96 & 1,9 & 1,02 & $-5,01$ & $-3,88$ & $-3,53$ & 2,95 & 1,86 & 1,3 & $-5,09$ & $-3,55$ & $-2,39$ & 8,34 & 3,62 & 1,27 & $-5,45$ & $-7,03$ \\
\hline CREBBP & $-6,42$ & 2,65 & 1,08 & $-4,81$ & $-5,32$ & $-1,74$ & $-7,64$ & 2,6 & 1,71 & $-2,72$ & $-5,54$ & $-2,83$ & $-5,69$ & 7,4 & 1,86 & $-5,51$ & $-6,24$ & $-3,05$ \\
\hline CX3CL1 & $-3,64$ & 0,94 & 2,38 & $-0,38$ & $-1,35$ & 0 & $-4,44$ & 1,02 & 2,22 & 0,99 & $-1,77$ & 0 & $-4,06$ & $-1,01$ & $-2,77$ & 0,92 & $-1,84$ & 0 \\
\hline CXCL12 & 0 & 0 & $-0,87$ & $-3,2$ & $-1,97$ & 10,34 & 0 & 0 & $-0,97$ & $-3,79$ & $-2,65$ & $-8,81$ & 0 & 11,35 & $-4,88$ & $-3,02$ & $-3,3$ & $-6,95$ \\
\hline CXCR4 & $-13,03$ & 4,47 & 0 & 0 & 0 & 0 & 0 & 6,43 & $-7,93$ & $-20,97$ & $-13,6$ & $-6,34$ & $-13,96$ & 9,76 & $-2,17$ & $-11,16$ & $-9,16$ & $-3,15$ \\
\hline ELANE & $-2,44$ & 0,56 & 5,54 & 1,76 & $-2,2$ & 6,91 & $-1,53$ & 1,02 & 5,52 & 2,98 & $-1,08$ & 7,93 & 2,81 & 6,52 & 8,49 & 3,14 & $-0,55$ & 1,12 \\
\hline EP300 & $-8,55$ & 3,35 & $-5,33$ & $-8,53$ & $-10,2$ & $-4,69$ & $-8,02$ & 3,83 & $-5,74$ & $-9,64$ & $-9,33$ & $-4,66$ & $-6,54$ & 5,78 & $-1,01$ & $-10,14$ & $-8,43$ & $-3,69$ \\
\hline FCAR & $-4,73$ & 1,2 & 4,99 & 0,65 & $-4,89$ & $-3,75$ & $-5,01$ & 1,13 & 4,99 & 1,57 & $-4,93$ & $-3,65$ & $-3,08$ & 6,29 & 6,72 & 1,58 & $-5,28$ & $-6,85$ \\
\hline FOS & 0 & $-12,22$ & $-8,39$ & 0 & 0 & 0 & 0 & $-5,76$ & $-10,1$ & $-22,64$ & $-17,67$ & 0 & 0 & 0 & $-16,89$ & 0 & $-23,4$ & 0 \\
\hline GADD45 & $-5,56$ & $-0,04$ & 2,27 & 2,4 & $-6,63$ & $-7,98$ & $-4,67$ & $-0,23$ & 2,26 & 0,94 & $-6,72$ & $-8,05$ & $-4,52$ & 5,1 & 2,82 & 0,68 & $-8,91$ & $-10,66$ \\
\hline $\mathrm{HCK}$ & $-1,51$ & 5,32 & 4,27 & 1,22 & $-1,87$ & 3,95 & $-2,4$ & 6,23 & 3,93 & 3,44 & $-0,8$ & 4,67 & 2,61 & 9,33 & 6,34 & 97 & $-0,28$ & 0,99 \\
\hline HMGA1 & $-3,84$ & 3,16 & 3,13 & 2,31 & $-3,27$ & 1,43 & $-4,27$ & 3,51 & 3,03 & 2,91 & $-2,57$ & 2,3 & $-0,03$ & 8,25 & 5,87 & 2,87 & $-1,67$ & $-2,91$ \\
\hline HTATSFF & $-3,76$ & 0,96 & 0,17 & $-5,32$ & -7 & 0,36 & $-5,37$ & 1,41 & $-0,18$ & $-3,23$ & $-6,66$ & 0,82 & $-2,47$ & 6,43 & 1,79 & $-3,33$ & $-7,17$ & 0,24 \\
\hline IFNA1 & $-4,49$ & 3,31 & 2,38 & 1,82 & $-5,38$ & $-4,43$ & $-4,25$ & 3,21 & 2,49 & 2,62 & $-5,52$ & $-4,46$ & $-3,07$ & 8,62 & 3,64 & 2,45 & $-6,22$ & $-7,52$ \\
\hline If & 0 & $-1,94$ & $-6,53$ & $-9,39$ & $-11,65$ & 0 & 0 & $-1,25$ & $-5,68$ & $-8,53$ & $-11,35$ & 0 & 0 & 3,69 & $-9,88$ & $-9,96$ & $-15,01$ & 0 \\
\hline & $-7,37$ & $-0,77$ & $-3,96$ & $-4,54$ & $-9,02$ & 0 & 0 & $-0,69$ & $-4,84$ & $-9,17$ & $-9,6$ & 0 & $-6,77$ & 4,02 & $-8,06$ & $-9,74$ & $-11,66$ & 0 \\
\hline $\begin{array}{l}\text { IL10 } \\
112 B\end{array}$ & $-6,58$ & $-0,41$ & 0,86 & $-2,03$ & $-3,59$ & $-7,7$ & $-7,64$ & $-2,02$ & 0,67 & $-3,13$ & $-4,97$ & $-4,96$ & $-2,75$ & 0,03 & $-4,25$ & $-2,42$ & $-5,87$ & $-9,7$ \\
\hline IL12B & 4,49 & 2,35 & 2,12 & $-6,49$ & $-2,84$ & 9,83 & 4,72 & 4,9 & 3,82 & $-2,52$ & $-1,56$ & 0 & 0 & 0 & 6,03 & -2 & 0,68 & 0 \\
\hline IL16 & $-5,95$ & $-0,72$ & 2,42 & $-0,13$ & $-8,06$ & $-5,21$ & $-7,45$ & $-0,97$ & 2,09 & $-1,66$ & $-8,79$ & $-4,56$ & $-6,28$ & 3,63 & 2,3 & $-2,03$ & $-10,54$ & $-5,56$ \\
\hline IL1B & $-3,14$ & $-2,81$ & 4,8 & 0,58 & $-8,28$ & 0 & $-6,48$ & $-4,36$ & 2,9 & $-3,08$ & $-9,47$ & 0 & $-6,55$ & $-8,65$ & $-4,13$ & $-5,03$ & $-10,23$ & 0 \\
\hline IL8 & $-4,43$ & $-1,12$ & 4,9 & 2,16 & $-8,6$ & 0,91 & $-5,55$ & $-2,03$ & 3,81 & $-0,35$ & $-9,06$ & $-0,27$ & $-0,05$ & 0,89 & 5,11 & $-1,52$ & $-9,06$ & $-6,99$ \\
\hline IRF1 & $-8,23$ & 0,85 & 2,85 & 1,18 & $-1,55$ & $-6,98$ & $-7,57$ & 1,18 & 3,21 & 1,39 & $-1,21$ & $-6,33$ & $-5,36$ & $-0,52$ & 1,24 & 1,75 & $-0,97$ & $-6,01$ \\
\hline IRF2 & $-4,77$ & 0,67 & 1,73 & 0,85 & $-6,32$ & $-6,39$ & $-3,84$ & 0,97 & 1,87 & 1,27 & $-5,77$ & $-6,03$ & $-2,02$ & 6,47 & 4,19 & 1,62 & $-5,76$ & $-10,49$ \\
\hline LTBR & $-4,13$ & 2,64 & 0,4 & 1,41 & 0 & $-3,71$ & $-4,73$ & 2,34 & 0,36 & 1,47 & $-0,18$ & $-4,09$ & $-4,69$ & 2,16 & $-1,26$ & 1,35 & $-0,34$ & $-3,83$ \\
\hline MAP3K5 & $-3,3$ & 2,58 & 1,42 & 0,24 & $-5,26$ & $-2,08$ & $-3,76$ & 3,17 & 1,73 & 1 & $-5,15$ & $-1,79$ & $-1,94$ & 0 & 3,06 & 0,7 & $-5,51$ & $-4,35$ \\
\hline MBL2 & $-1,04$ & 1,33 & $-4,73$ & $-11,32$ & $-10,43$ & $-5,73$ & $-0,4$ & 2,21 & $-3,19$ & $-9,71$ & $-10,69$ & $-5,07$ & $-1,08$ & 6,24 & $-0,5$ & $-11,85$ & $-12,15$ & 1,15 \\
\hline NFKBIA & $-3,19$ & 0,88 & 5,03 & 2,62 & 2,89 & 2,39 & $-3,43$ & 0,7 & 5 & 1,96 & 3,1 & 3,39 & $-2,85$ & 0,32 & 4,39 & 2,02 & 3,26 & 3,34 \\
\hline PPIA & 0 & 2,74 & 5,02 & 0,07 & $-2,14$ & 0 & 0 & 2,73 & 4,81 & 1,07 & $-2,33$ & 0 & 0 & 0,48 & $-0,71$ & 0,2 & -2 & 0 \\
\hline PRDX1 & $-1,22$ & 3,08 & 4,4 & 0,57 & $-3,73$ & 6,28 & $-2,72$ & 2,91 & 4,09 & 1,96 & $-3,56$ & 6,04 & $-0,2$ & 0 & 5,98 & 0,68 & $-2,56$ & 3,74 \\
\hline PTK2B & $-6,05$ & 0,75 & 3,59 & 0,39 & $-5,45$ & $-1,13$ & $-6,09$ & 1,26 & 3,85 & 1,76 & $-5,22$ & $-0,22$ & $-3,74$ & 6,44 & 5,87 & 1,42 & $-4,3$ & $-1,64$ \\
\hline RBL2 & 0 & 2,43 & 1,83 & 0,81 & $-2,22$ & 0 & 0 & 2,71 & 2,16 & 1,54 & $-2,41$ & 0 & 0 & 0,84 & $-1,49$ & 1,65 & $-2,51$ & 0 \\
\hline SELL & $-6,63$ & $-0,33$ & $-1,19$ & $-3,94$ & $-5,33$ & 0 & $-8,28$ & 0,2 & $-1,55$ & $-3,83$ & $-4,89$ & 0 & 0 & $-2,95$ & $-4,52$ & $-5,49$ & $-6,59$ & 0 \\
\hline SERPINA1 & $-4,72$ & $-0,3$ & 0,85 & $-1,85$ & $-8,38$ & $-5,51$ & $-3,27$ & $-0,22$ & 0,75 & $-1,7$ & $-8,56$ & $-4,93$ & $-3,18$ & 5,21 & 1,81 & $-3,26$ & $-9,03$ & $-8,55$ \\
\hline SERPINC1 & 2,56 & 2,24 & $-2,67$ & $-7,12$ & $-7,75$ & 3,73 & $-0,46$ & 2,86 & $-3,98$ & $-4,3$ & $-7,69$ & 4,41 & 4,21 & 0 & $-1,43$ & $-5,34$ & $-6,37$ & 2,32 \\
\hline SLPI & $-11,92$ & $-3,62$ & $-9,33$ & $-5,88$ & $-12,86$ & $-6,23$ & $-13,84$ & $-2,32$ & $-5,53$ & $-10,74$ & $-13,96$ & $-5,91$ & $-11,45$ & 0,41 & $-5,84$ & $-12,63$ & $-16,45$ & -5 \\
\hline SMARCB1 & $-4,83$ & 3,17 & 2 & 1,22 & $-5,67$ & $-6,02$ & $-3,97$ & 2,95 & 2,06 & 1,77 & $-6,06$ & $-6,21$ & $-3,06$ & 0 & 3,43 & 1,98 & $-6,69$ & $-9,31$ \\
\hline STAT1 & $-6,31$ & 1,22 & 1,23 & 1,67 & 0,77 & 1,57 & $-6,25$ & 1,11 & 1,22 & 2,13 & 0,61 & 2,33 & $-6,81$ & $-0,27$ & $-1,64$ & 2,09 & $-0,03$ & 2,22 \\
\hline STAT3 & $-1,97$ & 0,87 & 5,49 & 1 & $-0,02$ & 0 & $-2,79$ & 1,1 & 5,32 & 1,55 & 0,32 & 0 & $-1,99$ & 0,61 & 3,93 & 1,57 & 0,96 & 0 \\
\hline TFCP2 & $-4,56$ & 3,32 & 3,97 & $-0,21$ & $-5,92$ & $-4,87$ & $-4,22$ & 3,47 & 4,31 & 1,45 & $-5,79$ & $-5,05$ & $-3,73$ & 0 & 5,42 & 1,58 & $-6,3$ & $-6,79$ \\
\hline TGFB1 & $-4,76$ & 0,6 & 3,24 & 2,12 & $-3,46$ & $-6,09$ & $-2,9$ & $-0,15$ & 2,95 & 1,64 & $-5,03$ & $-7,23$ & $-2,08$ & 5,69 & 4,61 & 39 & $-7,01$ & $-12,19$ \\
\hline TNF & $-6,19$ & $-0,52$ & 4,28 & 2,51 & $-3,82$ & $-9,02$ & $-7,35$ & $-0,98$ & 4,38 & 0,17 & $-4,11$ & $-7,87$ & $-5,9$ & $-2,1$ & 0,81 & $-0,9$ & $-4,04$ & $-8,68$ \\
\hline TNFRSF1B & $-5,33$ & 0,49 & 0,58 & 1,26 & $-5,64$ & $-7,04$ & $-5,79$ & 0,47 & 0,37 & 1,74 & $-5,68$ & $-6,45$ & $-2,09$ & 4,82 & 2,26 & 1,68 & $-6,99$ & $-10,83$ \\
\hline TNFSF10 & $-8,48$ & $-2,12$ & 0,82 & $-3,89$ & $-8,64$ & 0 & $-12,15$ & $-1,36$ & $-1,05$ & $-5,41$ & $-8,88$ & 0 & 0 & $-0,41$ & $-2,73$ & $-6,4$ & $-9,59$ & 0 \\
\hline TRIM5 & $-5,12$ & 2,31 & 3,19 & $-1,06$ & $-5,75$ & $-3,61$ & $-5,74$ & 1,54 & 3,4 & 0,08 & $-5,97$ & $-3,7$ & $-3,32$ & 0 & 4,79 & 16 & $-6,61$ & $-6,77$ \\
\hline TSG101 & $-4,45$ & 2,49 & 1,58 & 0,81 & $-5,82$ & $-5,82$ & $-2,79$ & 2,64 & 1,61 & 1,27 & $-5,72$ & $-6,03$ & $-2,5$ & 0 & 3,88 & 1,38 & $-5,27$ & $-9,85$ \\
\hline VPS4A & $-4,51$ & 2,63 & 1,82 & 1,67 & $-4,95$ & $-3,88$ & $-3,85$ & 2,34 & 1,75 & 1,94 & $-5,2$ & $-3,78$ & $-2,18$ & 0 & 3,62 & 2,12 & $-5,48$ & $-7,76$ \\
\hline XPO1 & $-4,32$ & 2,23 & 0,47 & 1,14 & $-4,84$ & $-3,89$ & $-2,62$ & 2,2 & 0,42 & 1,56 & $-4,68$ & $-3,79$ & $-1,42$ & 0 & 3 & 1,67 & $-4,63$ & $-8,67$ \\
\hline YY1 & $-3,45$ & 1,98 & 1,02 & 1,59 & $-0,92$ & 0 & $-3,74$ & 1,8 & 1,03 & 2,06 & $-0,87$ & 0 & $-3,78$ & 1,36 & 2,6 & 2,19 & $-0,96$ & 0 \\
\hline
\end{tabular}




\section{APÊNDICE B - Perfil de expressão de leucócitos após a imunoterapia= P6-11 (FC)}

\begin{tabular}{|c|c|c|c|c|c|c|c|c|c|c|c|}
\hline & 6-t1 & P6- t 2 & P6- t3 & P7-t1 & P7- t 2 & P7- t3 & P8- t1 & P8- t3 & P9- t1 & P9- t 2 & P9- t3 \\
\hline$\triangle P O B E C 3 G$ & 1,26 & 0,99 & 1,03 & 0,86 & 1,74 & 1,04 & 0,86 & 0,50 & 0,99 & 0,73 & 0,74 \\
\hline$B A X$ & 1,27 & 1,11 & 0,76 & 2,07 & 0,39 & 3,58 & 0,78 & 0,69 & 1,25 & 0,91 & 0,89 \\
\hline$B C L 2$ & 16 & 51 & 0,37 & 76 & 0,75 & 5,03 & 1,27 & 0,88 &, 87 & 1,53 & 0,84 \\
\hline BST2 & 38 & 0,80 & 1,27 & 4,53 & 0,21 & 1,32 & 0,78 & 0,77 & 4,32 & 0,26 & 6,59 \\
\hline CASP1 & 1,59 & 0,76 & 1,26 & 11,39 & 0,09 & 2,23 & 0,82 & 0,65 & 1,60 & 0,28 & 3,12 \\
\hline CASP3 & 1,65 & 0,70 & 0,95 & 1,88 & 0,35 & 3,81 & 0,81 & 0,44 & 1,58 & 0,80 & 0,47 \\
\hline CCl19 & 3,46 & 0,00 & 0,86 & 0,00 & 0,31 & 243,88 & 0,37 & 0,00 & 0,00 & 0,00 & 0,00 \\
\hline$C C L 2$ & 1,23 & 0,74 & 0,00 & 0,03 & 8,94 & 1,61 & 0,29 & 0,18 & 0,95 & 1,40 & 0,79 \\
\hline CCL2O & 27 & 0,59 & 2,31 & 0,00 & 21,86 & 1,02 & 0,23 & 0,00 & 0,54 & 0,28 & 1,09 \\
\hline$C C L 3$ & 22 & 0,44 & 0,75 & 0,09 & 9,71 & 0,84 & ,23 & 1,54 & 0,87 & 2,97 & 0,16 \\
\hline CCL4 & 0,99 & 1,03 & 0,64 & 0,28 & 9,06 & 0,09 & 0,65 & 0,29 & 0,47 & 5,39 & 0,02 \\
\hline$C C L 5$ & 0,90 & 1,52 & 0,75 & 1,08 & 1,71 & 0,12 & 1,23 & 86 & 0,68 & 5,43 & 0,10 \\
\hline CCR5 & 1,13 & 1,43 & 0,85 & 1,46 & 0,63 & 2,22 & 0,71 & 73 & 1,25 & 0,58 & 1,43 \\
\hline CCR6 & 1,20 & 1,52 & 0,59 & 0,93 & 0,58 & 1,79 & 1,64 & 1,06 & 0,41 & 1,57 & 0,42 \\
\hline$C C R 7$ & 1,29 & 1,45 & 0,50 & 0,05 & 19,43 & 0,04 & 1,11 & 0,42 & 1,96 & 2,04 & 0,10 \\
\hline CD127 & 0,86 & 1,56 & 0,32 & 0,69 & 2,64 & 0,22 & 2,01 & 0,90 & 2,66 & 1,04 & 0,48 \\
\hline CD14 & 1,20 & 0,66 & 1,80 & 18,38 & 0,04 & 9,38 & 0,47 & 34 & 3,23 & 0,30 & 3,46 \\
\hline CD16 & 1 , & 0,81 & 0,75 & 12,55 & 0,05 & 12,38 & 0,66 & 61 & 15,14 & 0,03 & 34,06 \\
\hline$C D 25$ & 1,79 & 0,71 & 0,94 & 1,05 & 0,72 & 0,29 & 0,86 & 76 & 1,23 & 0,69 & 2,20 \\
\hline$C D 27$ & 1 & 5,13 & 0,00 & 0,52 & 0,60 & 48,50 & 0,45 & 88 & 1,24 & 0,90 & 0,97 \\
\hline CD38 & 1 , & 1,05 & 0,58 & 1,28 & 0,51 & 210 & 1,36 & 43 & 0,57 & 2,13 & 0,19 \\
\hline CD4OL & 1,21 & 1,36 & 0,54 & 0,44 & 2,04 & 12,7 & 1,23 & 75 & 1,10 & 1,01 & 0, \\
\hline CD45RO & 1,39 & 0,75 & 0,62 & 0,82 & 1,96 & 0,66 & 0,92 & 02 & 0,93 & 0,82 & 0,8 \\
\hline CD56 & 0,99 & 1,73 & 0,23 & 2,28 & 1,57 & 5,31 & 2,03 & 2,01 & 0,10 & 1,46 & 0 \\
\hline CD69 & 1,31 & 0,51 & 0,32 & 0,74 & 2,38 & 0,14 & 0,64 & 41 & 0,12 & 8,28 & 0,1 \\
\hline CNOT1 & 1,48 & 0,75 & 0,44 & 1,54 & 0,66 & 0,58 & 1,21 & 67 & 0,71 & 1,47 & 0,26 \\
\hline CTLA-4 & 2,07 & 0,76 & 0,35 & 0,38 & 2,58 & 1,7 & 1,56 & 88 & 0,29 & 2,58 & 0,31 \\
\hline CXCL10 & 1,53 & 2,00 & 0,84 & 1,48 & 0,84 & 18,9 & 0,58 & 34 & 3,18 & 0,12 & 4,11 \\
\hline CXCL11 & 2 , & 4,03 & 0,58 & 4,26 & 0,28 & 113,77 & 0,51 & 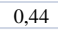 & 0,00 & 0,09 & 5, \\
\hline CXCL12 & 3 & 0,00 & 0,00 & 0 & 0,00 & 0,00 & 0 & 00 & 0,00 & 0,00 & 0,00 \\
\hline CXCL9 & 1 . & 0,96 & 1,88 & 92 & 0,17 & 2149,82 & 83 & 43 & 1,22 & 0,20 & 1,75 \\
\hline CXCR5 & 1,53 & 0,97 & 0,21 & 0,36 & 1,44 & 1,12 & 1,56 & 11 & 0,78 & 1,85 & 0 , \\
\hline EOMES & 1,16 & 1,48 & 0,62 & 0,72 & 1,42 & 0 , & 0,94 & 75 & 1,00 & 2,68 & 0,1 \\
\hline$F A S$ & 1,51 & 0,78 & 1,13 & 6,82 & 0,28 & 1,46 & 0,94 & 50 & 3,48 & 0,14 & 6,11 \\
\hline FASL & 1, & 1,34 & 1,11 & 0,03 & 9,78 & 3,94 & 0,97 & 51 & 0,27 & 2,16 & 0, \\
\hline FOXP3 & 1, & 1,32 & 0,32 & 1,14 & 1,02 & 139,10 & 1,46 & 90 & 1,25 & 0,39 & 0,97 \\
\hline GATA3 & 1,10 & 1,12 & 0,37 & 0,66 & 2,16 & 11,63 & 1,29 & & 2,30 & 1,04 & 0,21 \\
\hline GZMA & 0,8 & 1,09 & 0,55 & 9,00 & 0,25 & 3 , & 1,1 & & 0,50 & 3,27 & 0 , \\
\hline GZMB & 1,06 & 1,71 & 0,56 & 0,29 & 2,55 & 1,2 & 1,13 & 97 & 0,29 & 4,72 & 0,1 \\
\hline ICOS & 0,7 & 1,11 & 0,21 & 0,31 & 10,56 & 0,48 & 0,64 & 27 & 0,23 & 2,85 & 0,08 \\
\hline$I D O$ & 2 & 0,47 & 0,99 & 11,00 & 0,03 & 48,50 & 0,82 & 36 & 10,34 & 0,03 & 93,05 \\
\hline IFI6 & 1,65 & 0,81 & 1,23 & 6,02 & 0,17 & 336 & 0,77 & 64 & 1,62 & 0,34 & 3,61 \\
\hline IFNAI & 3, & 0,00 & 0, & 0,00 & 0,00 & & 0,35 & 2 & 0,00 & 0,00 & 0 , \\
\hline IFNG & 1,3 & 1,30 & 0,12 & 0,68 & 5,31 & 1,12 & 1,15 & 62 & 0,44 & 2,45 & $0, \mathrm{C}$ \\
\hline IL10 & 1,5 & 4,47 & 0,54 & 0,28 & 0,86 & 34,54 & 1,21 & 80 & 0,65 & 0,78 & 0, \\
\hline ILI3 & 2, & 0,25 & 0,24 & 6,02 & 0,28 & 2957,17 & 1,64 & 62 & 0,88 & 0,22 & 1,11 \\
\hline IL15 & 1 , & 1,30 & 0,51 & 8,46 & 0,10 & 9,32 & 1,14 & 55 & 0,63 & 0,87 & 0,67 \\
\hline IL17 & 2, & 0,00 & 0 & 0 , & 0,00 & 282,09 & 0,00 & 00 & 0,00 & 0,00 & 0, \\
\hline IL1A & 1, & 0,00 & 0,23 & 0 , & 6,28 & 33,82 & 0,49 &, 08 & 0,00 & 0,41 & 0 \\
\hline$I L 1 B$ & 1,4 & 0,85 & 3,05 & 0,1 & 1,95 & 0,33 & 0,82 & 1,05 & 0,96 & 0,55 & 1,2 \\
\hline IL22 & 0 , & 1,30 & 0,51 & 4, & 0,34 & 1871,53 & 0,71 & & 3,25 & 0,21 & 2,7 \\
\hline IL $23 A$ & 1, & 2,28 & 0,24 & 0,09 & 5,24 & 0,46 & 0,73 & 72 & 1,53 & 0,45 & 1,92 \\
\hline IL27 & 3, & 0,67 & 0,76 & 10,20 & 0,07 & 744,43 & 0,93 & 0,47 & 11,24 & 0,02 & 49,52 \\
\hline IL4 & 2, & 0,79 & 1,7 & 0 , & 0,33 & 501,46 & 0 , & 2 & 0, & 0,00 & 0,00 \\
\hline$I L 5$ & 2,00 & 4,9 & 0, & 0 , & 0,0 & 0 & 0,00 &, 00 & 0, & 0,58 & 0 \\
\hline IL6 & 1 , & 0,35 & 0,20 & 0 , & 3,66 & 5,03 & 0,10 & 00 & 0,0 & 3,10 & 0, \\
\hline IL7 & & 1,93 & 0,5 & & 1,85 & 3,03 & 4,44 & 41 & 0,30 & 1,34 & 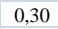 \\
\hline ILS & \begin{tabular}{|l|}
1,09 \\
\end{tabular} & 0,16 & 0,16 & 2,30 & 0,99 & 2,08 & 0,43 & 46 & 4,44 & 0,59 & 1, \\
\hline IRF3 & 1, & 1,17 & & & 0,3 & & & & 1 , & $1, \mathrm{C}$ & \\
\hline IRF7 & 2 & 1,1 & & & 0 , & & 0 & & 2 , & 0 , & \\
\hline ISG15 & 2 & 0,7 & 0 , & 2 & 0,3 & 0,35 & 0,8 & & 5 , & 0,21 & 6,73 \\
\hline KIR $3 D L 1$ & 1, & 1,24 & 0,69 & 0,28 & 1,13 & 12,64 & 1,05 & 67 & 0,85 & 0,34 & 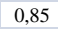 \\
\hline KIR3DSI & 1,0 & 1,72 & 0 , & 0,00 & 0,00 & 0 , & 1 , & 0 & 0,39 & 2,14 & 0,18 \\
\hline LAG3 & 1, & 1,0 & 0 & 1 , & 1,3 & & & & 1,2 & 1,22 & \\
\hline LAMPI & & , & 1, & & & & & & & & \\
\hline$M x I$ & 3 & 0,7 & 1,2 & 10,63 & 0,0 & & 1 , & & 3, & 0 , & \\
\hline Myd $d 88$ & & 0,6 & & 2, & 0,3 & & & & 1, & 0,7 & 1,56 \\
\hline$N K G 2 D$ & 1, & 1,21 & 0,59 & 3,78 & 0,48 & 0,68 & 0 & 54 & 0,53 & 4,92 & 0, \\
\hline NKp $44 L$ & 1, & 0,8 & 0, & & 0,5 & 2,3 & & & 0 , & 2 , & \\
\hline OASI & 2, & 1,0 & 1, & 10 & 0 & 1, & & & & & \\
\hline PARD $3 B$ & & 0,5 & & & & & & & 0 , & & \\
\hline וס & & & & & & & & & & 1, & \\
\hline PDL1 & 1 , & 0,60 & 1, & 5,54 & 0,20 & 27,47 & 1,2 & 00 & 4,23 & 0,02 & 50,56 \\
\hline PPIA & 1,0 & 0,91 & 0 , & 1,8 & 1,0 & 1,4 & 1 , & 30 & 0,23 & 5,24 & 0,0 \\
\hline PRF1 & & 1,5 & & 1 , & 0,5 & & & & 0 , & & 0 , \\
\hline RORC & & & & & & & & & & & \\
\hline SLFN11 & & 1 , & & & 0 , & & & & & & \\
\hline STATI & & 0,82 & & 9 & 0 , & 1,25 & 0 , & 52 & 1,59 & 0,36 & 3,0 \\
\hline TAPI & 1,88 & 0,77 & 0,9 & 1,47 & 0,51 & 0,49 & 0,67 & 0,51 & 3,41 & 0,20 & 4,79 \\
\hline TBET & 1, & 1,2 & 0 , & 0 , & 1,3 & & & & 0 , & 5 , & 0 , \\
\hline$T G F B$ & & 0,9 & & & 3,1 & & & & & 0, & \\
\hline TIN & & 1 , & & & 2,2 & & & & 0 , & & \\
\hline & & & & & & & & & 2 , & & \\
\hline TNFSF 10 & 2,4 & 0,51 & 1,64 & 20,39 & 0,05 & 13,27 & 0 , & 0,57 & 8,63 & 0,05 & 27,28 \\
\hline TRIM5 & 1,88 & 1,27 & 1,2 & 4,92 & 0,15 & 110,66 & 0,9 & 0,9 & 2,68 & 0,3 & 2, \\
\hline XIAP & 1,88 & 0,69 & 0,77 & 1,64 & 0,59 & 3,25 & 0,81 & 0,66 & 0,69 & 1,36 & 0,39 \\
\hline
\end{tabular}




\section{APÊNDICE C - Heat map do perfil de expressão dos leucócitos de 6 indivíduos HIV submetidos à imunoterapia nos tempos $\mathrm{t} 1, \mathrm{t} 2 \mathrm{e} \mathbf{t} 3$}

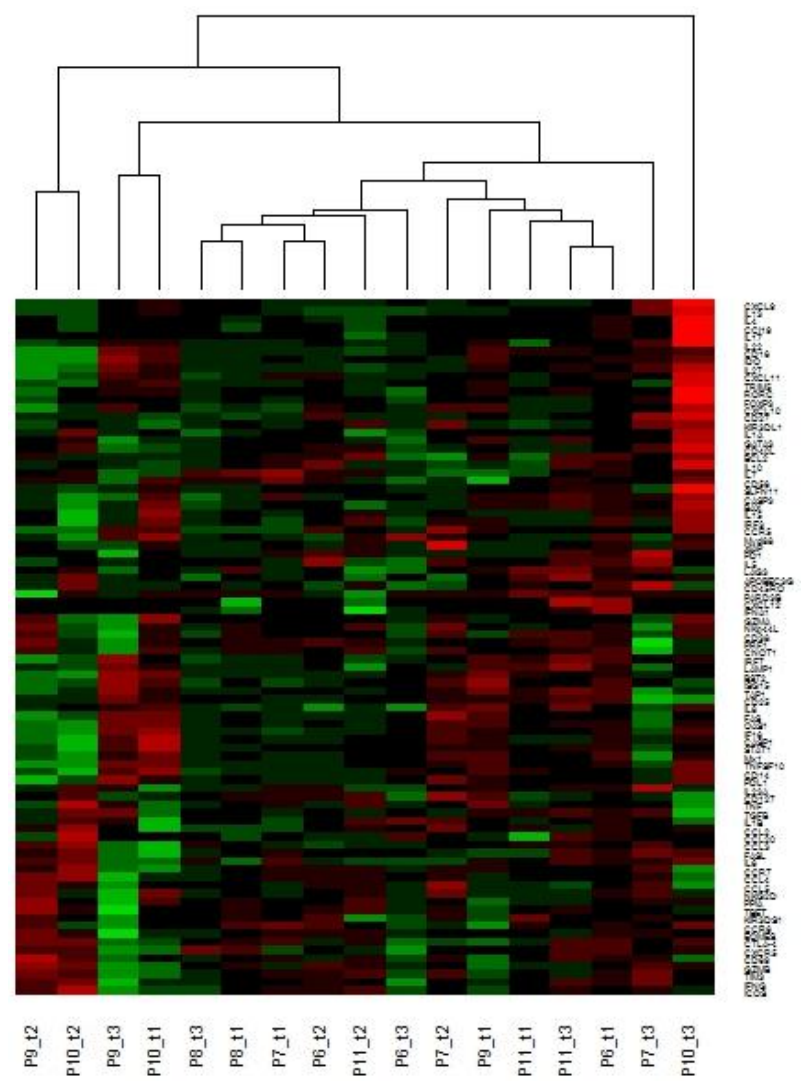

Figura 27 - Heat map do perfil de expressão dos leucócitos de 6 indivíduos HIV submetidos à imunoterapia nos tempos t1, t2 e t3. Os valores de $\log _{2}$ de $\mathrm{FC}$ foram plotados de forma linear com tons de verde, vermelho e preto atribuídos para cada valor, sendo que tons de verde indicam genes subexpressos (com valores de $\log _{2} \mathrm{FC}$ negativos), tons de vermelho indicam os superexpressos (com valores de $\log _{2}$ de FC positivos) e preto indica uma não modulação ou expressão. $\mathrm{O}$ dendograma superior horizontal mostra o agrupamento das amostras.

\section{APÊNDICE D - Resultados Genemania modulação oposta entre P7 e maus respondedores}

\begin{tabular}{|c|c|c|c|c|c|}
\hline \multicolumn{6}{|c|}{ FUNÇÕES } \\
\hline t1 & & t2 & & t3 & \\
\hline Up-regulated & & Up-regulated & & Up-regulated & \\
\hline Proliferação de células T ativadas & $4.25 \mathrm{e}-4$ & Resposta a interferon do tipo I & $3.49 \mathrm{e}-21$ & Ativação de células T & $2.29 \mathrm{e}-11$ \\
\hline Resposta imune adaptativa & $3.14 \mathrm{e}-3$ & Resposta celular de interferon do tipo I & $3.49 \mathrm{e}-21$ & Citotoxicidade mediada por NK & $2.29 \mathrm{e}-11$ \\
\hline Resposta imune adaptativa baseada na recombinação somática & $9.88 \mathrm{e}-4$ & Via de sinalização de interferon do tipo 1 & $3.49 \mathrm{e}-21$ & Imunidade mediada por NK & $2.29 \mathrm{e}-11$ \\
\hline Ativação celular de T alfa-beta & $4.59 \mathrm{e}-3$ & Regulação da replicação do genoma viral & $9.48 \mathrm{e}-14$ & Ligação de receptor a quimiocina CCR & $2.29 \mathrm{e}-11$ \\
\hline Ativação celular de T alfa-beta involvido na resposta imune & $4.01 \mathrm{e}-2$ & Resposta a vírus & $1.49 \mathrm{e}-13$ & Regulação da quimiotaxia de leucócitos & $2.29 \mathrm{e}-11$ \\
\hline Down-regulated & & Down-regulated & & & \\
\hline Resposta celular de interferon do tipo I & $3.91 \mathrm{e}-20$ & Coestimulação de linfócitos & $3.19 \mathrm{e}-13$ & & \\
\hline Via de sinalização de interferon do tipo 1 & $3.91 \mathrm{e}-20$ & Coestimulação de células T & $3.19 \mathrm{e}-13$ & & \\
\hline Resposta de interferon do tipo I & $3.91 \mathrm{e}-20$ & Regulação positiva da ativação de células $\mathrm{T}$ & $2.8 \mathrm{e}-12$ & & \\
\hline Resposta a vírus & 7.11e-11 & Regulação positiva da ativação de linfócitos & $1.17 \mathrm{e}-11$ & & \\
\hline Regulação negativa do processo & $4.27 \mathrm{e}-7$ & Ativação de células T & $1.34 \mathrm{e}-11$ & & \\
\hline
\end{tabular}




\section{ANEXO A - Arranjo de genes comercial usado nas etapas de diferenciação de DC}

\begin{tabular}{|c|}
\hline PCR Array Cat \\
\hline Position \\
\hline $\mathrm{A} 01$ \\
\hline $\mathrm{A} 02$ \\
\hline $\mathrm{A} 03$ \\
\hline A04 \\
\hline $\mathrm{A} 05$ \\
\hline $\mathrm{A} 06$ \\
\hline $\mathrm{A} 07$ \\
\hline $\mathrm{A} 08$ \\
\hline $\mathrm{A} 09$ \\
\hline $\mathrm{A} 10$ \\
\hline A11 \\
\hline A12 \\
\hline B01 \\
\hline $\mathrm{B} 02$ \\
\hline $\mathrm{B} 03$ \\
\hline B04 \\
\hline B05 \\
\hline$B 06$ \\
\hline \begin{tabular}{|l|l} 
\\
\end{tabular} \\
\hline B08 \\
\hline B09 \\
\hline$B 10$ \\
\hline B11 \\
\hline B12 \\
\hline $\mathrm{C} 01$ \\
\hline $\mathrm{C} 02$ \\
\hline $\mathrm{CO3}$ \\
\hline $\mathrm{CO} 4$ \\
\hline \begin{tabular}{|c|}
$\mathrm{CO}$ \\
\end{tabular} \\
\hline $\mathrm{CO}$ \\
\hline $\mathrm{C} 07$ \\
\hline $\mathrm{C} 08$ \\
\hline $\begin{array}{ll}\mathrm{CO} \\
\end{array}$ \\
\hline \begin{tabular}{|l|l|}
$\mathrm{C}$ \\
\end{tabular} \\
\hline C11 \\
\hline C12 \\
\hline \begin{tabular}{|l|l} 
D01 \\
\end{tabular} \\
\hline \begin{tabular}{|l|} 
D02 \\
\end{tabular} \\
\hline D03 \\
\hline \begin{tabular}{|l|l|} 
\\
\end{tabular} \\
\hline D05 \\
\hline D06 \\
\hline \begin{tabular}{|l|} 
D07 \\
\end{tabular} \\
\hline D08 \\
\hline D09 \\
\hline \begin{tabular}{|l|l} 
D10 \\
\end{tabular} \\
\hline \begin{tabular}{|l|l} 
D1 \\
\end{tabular} \\
\hline $\mathrm{D} 12$ \\
\hline E01 \\
\hline E02 \\
\hline E03 \\
\hline E04 \\
\hline E05 \\
\hline E06 \\
\hline E07 \\
\hline E08 \\
\hline E09 \\
\hline E10 \\
\hline E11 \\
\hline $\mathrm{E} 12$ \\
\hline F01 \\
\hline F02 \\
\hline F03 \\
\hline \begin{tabular}{|l|l|} 
F0 \\
\end{tabular} \\
\hline F05 \\
\hline F06 \\
\hline F07 \\
\hline F08 \\
\hline F09 \\
\hline F10 \\
\hline $\mathrm{F} 11$ \\
\hline $\mathrm{F} 12$ \\
\hline $\mathrm{G} 01$ \\
\hline $\mathrm{G} 02$ \\
\hline $\mathrm{G} 03$ \\
\hline G04 \\
\hline G05 \\
\hline G06 \\
\hline $\mathrm{G} 07$ \\
\hline G08 \\
\hline G09 \\
\hline $\mathrm{G} 10$ \\
\hline G11 \\
\hline G12 \\
\hline H01 \\
\hline $\mathrm{H} 02$ \\
\hline HO3 \\
\hline HO4 \\
\hline HO5 \\
\hline H06 \\
\hline H07 \\
\hline H08 \\
\hline H09 \\
\hline $\mathrm{H} 10$ \\
\hline $\mathrm{H} 11$ \\
\hline $\mathrm{H} 12$ \\
\hline
\end{tabular}




\section{ANEXO B - Arranjo de genes customizado usado em leucócitos antes/após imunoterapia}

Product Specification Sheet

\section{$\mathrm{RT}^{2}$ Profiler $^{\mathrm{TM}}$ PCR Array: CAPH12563 Custom Human RT ${ }^{2}$ Profiler ${ }^{\text {TM }}$ PCR Array}

\section{Array Layout}

\begin{tabular}{|c|c|c|c|c|c|c|c|c|c|c|c|c|}
\hline & 1 & 2 & 3 & 4 & 5 & 6 & 7 & 8 & 9 & 10 & 11 & 12 \\
\hline A & APOBEC $3 G$ & BAX & $\mathrm{BCL2}$ & BST2 & CASP1 & CASP 3 & CCL19 & $\mathrm{CCl} 2$ & $\mathrm{CCL}_{20}$ & $\mathrm{CCL} 3$ & $\mathrm{CCL} 4$ & CCL5 \\
\hline $\mathrm{B}^{-}$ & CCk5 & CCR6 & CCR7 & ILTR & $\mathrm{CO} 14$ & FCGR3B & ISG 20 & $\mathrm{CD} 27$ & $\cos 8$ & CDAOLG & PTPRC & NCAM1 \\
\hline C & CD69 & CNOT1 & CTLA4 & CXCL10 & CXCL11 & CXCL12 & $\mathrm{CXCl9}$ & CXCR5 & EOMES & FAS & FASLG & FOXp3 \\
\hline D & GATA3 & GZMA & GZMB & $1 \cos$ & 1001 & IF116 & IFNA1 & IFNG & IL10 & $\mathrm{IL13}$ & IL15 & IL17A \\
\hline E & ILIA & IL18 & 1122 & $1123 \mathrm{~A}$ & 1127 & 1144 & IL5 & IL6 & IL7 & 118 & IRF 3 & IRF7 \\
\hline $\mathbf{F}$ & ISG15 & KIR3DL1 & KIR3DS1 & $\angle A G 3$ & LAMP1 & $M X 1$ & MYDBB & KLRK1 & KMTZE & OAS1 & PARD3B & POCD 1 \\
\hline G & $\mathrm{CD} 274$ & PPIA & PQF1 & RORC & SLFN11 & STAT1 & TAP1 & TBX21 & TGFB1 & HAVCR2 & TNF & TNFSF 10 \\
\hline H & TRIM5 & XIAP & ACTB & GAPDH & HPRT1 & HGDC & RTC & RTC & RTC & $P P C$ & $P P C$ & $P P C$ \\
\hline
\end{tabular}

\section{Gene Table}

\begin{tabular}{|c|c|c|c|c|}
\hline Position & UniGene & GenBank & Symbol & Description \\
\hline A01 & Hs.660143 & NM_021822 & APOBEC 3G & $\begin{array}{l}\text { Apolipoprotein B mRNA editing enzyme, catalytic polypeptide-like } \\
\text { 3G }\end{array}$ \\
\hline $\mathrm{A} 02$ & Hs.624291 & NM_004324 & BAX & BCL.2-associated $X$ protein \\
\hline $\mathrm{A} 03$ & Hs.150749 & NM_000633 & BCL2 & B-cell CLL/lymphoma 2 \\
\hline $\mathrm{AO} 4$ & Hs.118110 & NM_004335 & BST2 & Bone marrow stromal cell antigen 2 \\
\hline A05 & Hs. 2490 & NM_033292 & CASP1 & $\begin{array}{l}\text { Caspase 1, apoptosis-related cysteine peptidase (interleukin 1, } \\
\text { beta, convertase) }\end{array}$ \\
\hline A06 & Hs. 141125 & NM_004346 & CASP3 & Caspase 3, apoptosis-related cysteine peptidase \\
\hline A07 & Hs.50002 & NM_006274 & CCL19 & Chemokine ( $\mathrm{C}-\mathrm{C}$ motif) ligand 19 \\
\hline $\mathrm{A} 0 \mathrm{~B}$ & Hs. 303649 & NM_002982 & $\mathrm{CCL} 2$ & Chemokine ( $\mathrm{C}-\mathrm{C}$ motif) ligand 2 \\
\hline A09 & $\mathrm{Hs}, 75498$ & NM_004591 & $\mathrm{Ca} 20$ & Chemokine (C.C motif) ligand 20 \\
\hline A10 & Hs.514107 & NM_002983 & $\mathrm{CCL} 3$ & Chemokine (C.C motif) ligand 3 \\
\hline A11 & Hs.75703 & NM_002984 & $\mathrm{CCL} .4$ & Chemokine ( $\mathrm{C}-\mathrm{C}$ motif) ligand 4 \\
\hline A12 & Hs. 514821 & NM_002985 & Ca.5 & Chemokine ( $\mathrm{C}-\mathrm{C}$ motif) ligand $\mathrm{S}$ \\
\hline $\mathrm{B} 01$ & Hs.450802 & NM_000579 & CCR5 & Chemokine ( $\mathrm{C}-\mathrm{C}$ motif) receptor 5 \\
\hline 802 & Hs.46468 & NM_004367 & CCR6 6 & Chemokine (C-C motif) receptor 6 \\
\hline $\mathrm{B} 03$ & Hs. 370036 & NM_001838 & CCR7 7 & Chemokine ( $\mathrm{C}-\mathrm{C}$ motif) receptor 7 \\
\hline B04 & Hs.591742 & NM_002185 & IL7R & Interleukin 7 receptor \\
\hline B05 & Hs. 163867 & NM_000591 & CD14 & CD14 molecule \\
\hline 806 & Hs. 372679 & NM_ 000570 & FCGR3B & Fc fragment of lgG, low affinity IItb, receptor (CD16b) \\
\hline 807 & Hs.459265 & NM_002201 & ISG20 & Interferon stimulated exonuclease gene $20 \mathrm{kDa}$ \\
\hline 808 & Hs. 355307 & NM_001242 & $\mathrm{CD} 27$ & CD27 molecule \\
\hline 809 & Hs.479214 & NM_001775 & $\operatorname{CD} 38$ & CD38 molecule \\
\hline 810 & Hs.592244 & NM_000074 & CD40LG & CD40 ligand \\
\hline B11 & Hs.654514 & NM_002838 & PTPRC & Protein tyrosine phosphatase, receptor type, C \\
\hline$B 12$ & Hs.711235 & NM_000615 & NCAM1 & Neural cell adhesion molecule 1 \\
\hline $\mathrm{CO1}$ & Hs. 208854 & NM_001781 & CD69 & CD69 molecule \\
\hline $\mathrm{CO} 2$ & Hs.731691 & MM_016284 & CNOT1 & CCR4-NOT transcription complex, subunit 1 \\
\hline $\mathrm{CO} 3$ & Hs. 247824 & NM_005214 & CTLA4 & Cytotoxic T-lymphocyte-associated protein 4 \\
\hline $\mathrm{CO} 4$ & Hs.632586 & NM_001565 & CXCL10 & Chemokine $(\mathrm{C}-\mathrm{X}-\mathrm{C}$ motif) ligand 10 \\
\hline $\cos$ & Hs.632592 & NM_005409 & CXCL11 & Chemokine ( $\mathrm{C}-\mathrm{X}-\mathrm{C}$ motif) ligand 11 \\
\hline $\cos$ & Hs.522891 & NM_000609 & $\mathrm{CXCL} 12$ & Chemokine ( $\mathrm{C}-\mathrm{X}-\mathrm{C}$ motif) ligand 12 \\
\hline $\mathrm{CO}$ & Hs. 77367 & NM_002416 & CXCL.9 & Chemokine ( $\mathrm{C}-\mathrm{X}-\mathrm{C}$ motif) ligand 9 \\
\hline $\cos$ & Hs.113916 & NM_001716 & CXCRS & Chemokine ( $\mathrm{C}-\mathrm{X}-\mathrm{C}$ motif) receptor $\mathrm{S}$ \\
\hline $\operatorname{COg}$ & Hs.734211 & NM_005442 & EOMES & Eomesodermin \\
\hline C10 & Hs. 244139 & NM_ 000043 & FAS & Fas (TNF receptor superfamily, member 6) \\
\hline
\end{tabular}




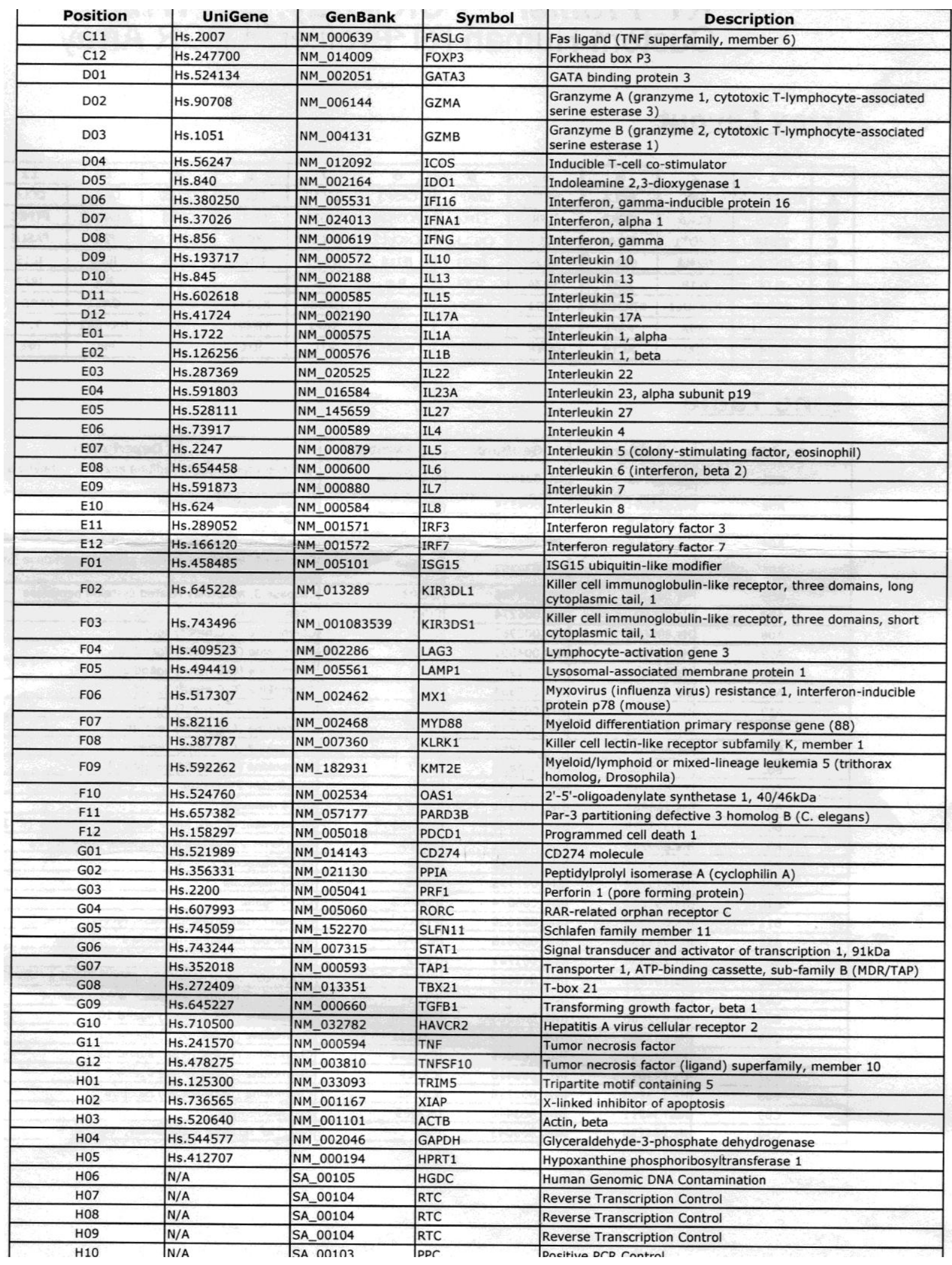

\begin{tabular}{|l|l|l|l|l|} 
H11 & N/A & SA_00103 & PPC & Positive PCR Control \\
\hline H12 & N/A & SA_00103 & PPC & Positive PCR Control \\
\hline
\end{tabular}

